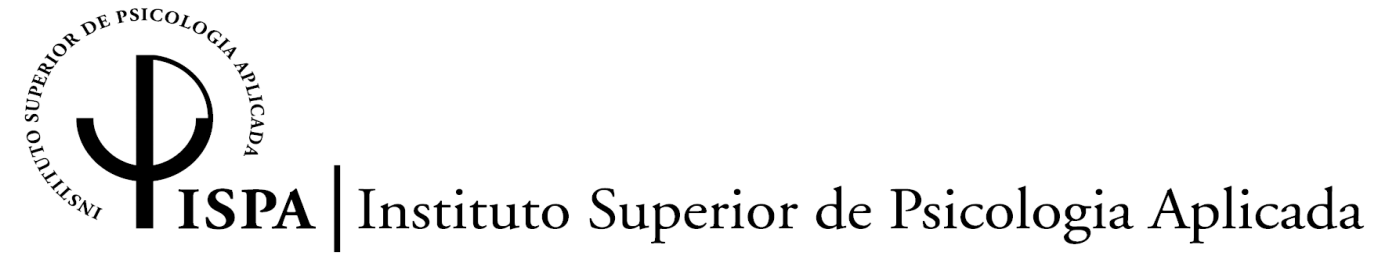

\author{
INTELIGÊNCIA EMOCIONAL NAS ORGANIZAÇÕES: \\ COLABORADORES MOTIVADOS E COM DESEMPENHO \\ EMOCIONALMENTE INTELIGENTE?
}

RAQUEL MARIA BAPTISTA GRILO

\author{
Orientador de Dissertação \\ PROF. DOUTOR JOAQUIM PINTO COELHO \\ Coordenador do Seminário de Dissertação \\ PROF. DOUTOR JOAQUIM PINTO COELHO
}
Tese submetida como requisito parcial para a obtenção do grau de Mestre em Psicologia Social e das Organizações


Dissertação de Mestrado realizada sob a orientação de Prof. Doutor Joaquim Pinto Coelho, apresentada no Instituto Superior de Psicologia Aplicada para obtenção de grau de Mestre na especialidade de Psicologia Social e das Organizações, conforme despacho da DGES no 19673 / 2006 publicado em Diário da República $2^{\mathrm{a}}$ séria de 26 de Setembro. 
Agradecimentos

Este é, na minha opinião, um dos capítulos mais importantes desta tese, por ser aqui que posso mencionar o nome de pessoas que são muito especiais e que sem elas não seria possível alcançar o objectivo de terminar este trabalho para finalizar o curso.

Ao Prof. Doutor Joaquim Pinto Coelho, meu orientador, pelo constante incentivo, pelas palavras de apoio nos bons e maus momentos e por me fazer acreditar que este trabalho sería exequível mesmo diante de tantas contrariedades. Também este agradecimento, pela pessoa generosa que foi comigo, dispendendo muitas vezes do tempo que tinha e que não tinha e pela paciência que teve para ler os infindáveis e-mails e para ainda lhes dar resposta célere em todas as situações. Muitas decisões são tomadas na vida e sem dúvida que uma das melhores foi o dia em que escolhi o Prof. Pinto Coelho para ser meu orientador, decisão essa que é confirmada com o término deste trabalho. Muito obrigada por tudo e o Professor Joaquim Pinto Coelho superou qualquer expectativa de orientador que eu pudesse imaginar.

Um agradecimento do fundo do coração aos meus pais que durante toda a minha vida de estudante me apoiaram, nos momentos bons e menos bons, e que me ensinaram sempre a ultrapassar as dificuldades, mostrando-me sempre que estas seríam ultrapassáveis e que estaríam sempre ao meu lado lado para me ajudar nesse caminho. Pela preocupação, pela compreensão, pela força, pelas palavras de incentivo, por estarem sempre disponíveis para me ajudar a qualquer hora e em qualquer situação. Pelas horas de "seca" na faculdade fazendo-me companhia enquanto eu trabalhava, e por toda a perserverança que me ensinaram a ter para alcançar todos os objectivos a que me proponho. Foi com o apoio deles durante estes anos de faculdade, que tive força para terminar este trabalho e o meu curso que está prestes a ser finalizado.

Ao Prof. Dr. Francisco Cesário, meu orientador de estágio, pelas fantásticas aprendizagens que me proporcionou. Por toda a disponibilidade que demonstrou mesmo depois de tanto tempo de ausência da minha parte, por me ter apoiado na continuação desta tese e na definição do caminho a seguir. Na minha opinião este é sem dúvida um dos melhores profissionais que colaboram com o ISPA e foi um dos professores que mais me marcou no meu caminho nesta Instituíção. 
Ao Prof. Dr. Pedro Almeida, um dos meus professores de seminário. Pela mais valia na orientação do Seminário, que me permitiu nas suas aulas espaços para discussão de algumas questões relevantes e importantes para o desenvolvimento deste trabalho, pelo constante entusiasmo nos assuntos que aborda e pela preocupação e palavras de incentivo para terminar a tese.

À Professora Dra. Maria Helena Almeida, da Universidade do Algarve, pela disponibilidade de me ceder a escala de motivação utilizada neste estudo e toda a informação possível sobre a mesma.

À Dra. Teresa Coelho, minha "chefe", pelo apoio que me deu no desenvolvimento deste trabalho e pela sua ajuda na recolha da amostra que sem a mesma não tería sido possível realizar este estudo. Pela ajuda na formulação e construção do estudo e pelas palavras de incentivo para terminar esta fase da minha vida.

Ao meu "chefinho" Manuel Guerreiro e às minhas colegas de trabalho e amigas, Sheila Silva, , Dina Branco e Cláudia Ramalho (desculpem aqueles cujo o nome não referi), pelo apoio nas horas em que estive ausente para realizar esta tese e pelas continuas palavras de incentivo que foram muito importantes para continuar a realização deste trabalho e para "o terminar de uma vez por todas".

E por último, mas não menos importantes, à minha colega e amiga, Inês Saúde, pela companhia em tantas horas de faculdade e incentivo neste caminho longo de seminários de Tese e à minha colega e amiga, Carla Barros, pela ajuda, apoio constante, partilha de conhecimentos e inquietações, incentivo e solidariedade demonstrados e por ter sido a pessoa que mais me marcou na minha vida de estudante do ISPA. 


\section{INDÍCE}

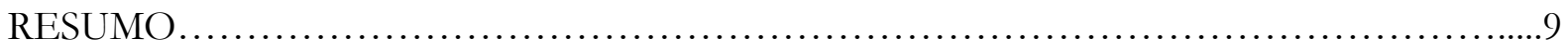

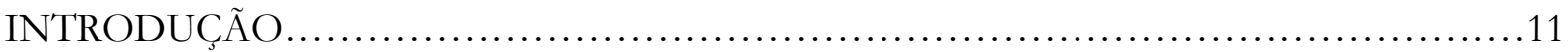

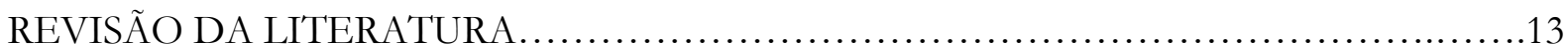

Inteligência Emocional...................................................... 13

Pertinência do estudo da Inteligência Emocional ................................13

Abordagens da Inteligência Emocional........................................15

Abordagem Corporativa da Inteligência Emocional.............................15

Abordagem Académica e Científica da Inteligência Emocional....................17

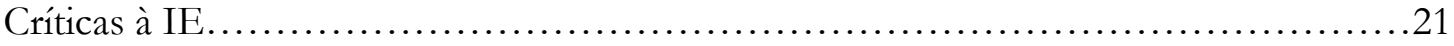

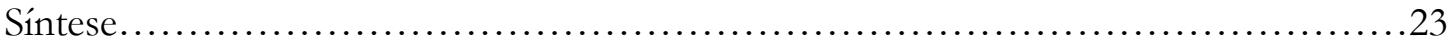

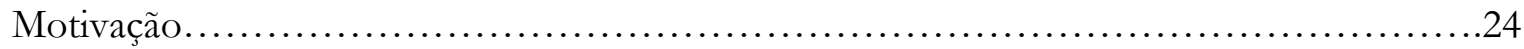

Abordagem Geral.........................................................24

Teorias da Motivação........................................................... 25

Teoria das Caracteristicas da Função.............................................26

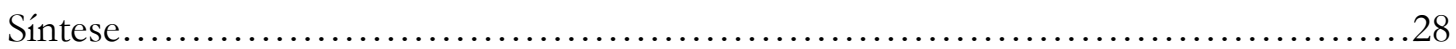

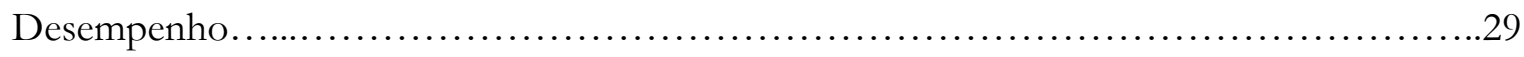

Abordagem Geral.........................................................29

Avaliação de Desempenho.......................................................31

Síntese........................................................................

Objectivos e Hipóteses de Investigação....................................... 35

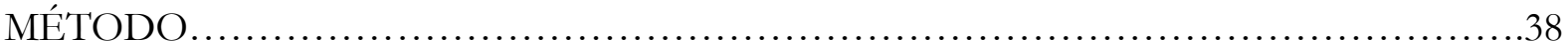

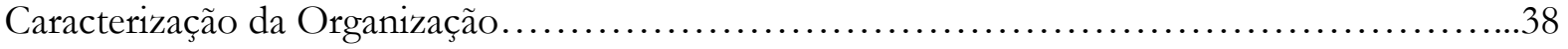

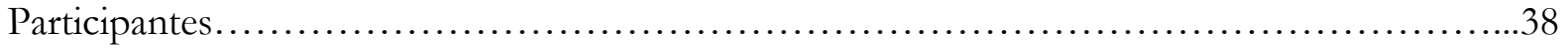

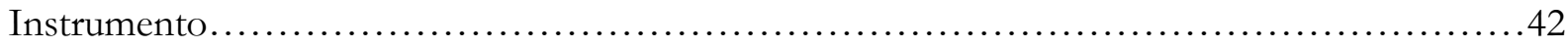

Inteligência Emocional......................................................42

Motivação.....................................................................44

Avaliação de Desempenho......................................................45

Design............................................................... 46

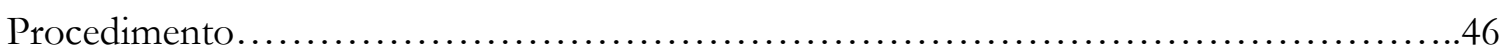


RESULTADOS

Estudo das Propriedades Psicométricas das Escalas.....................................48

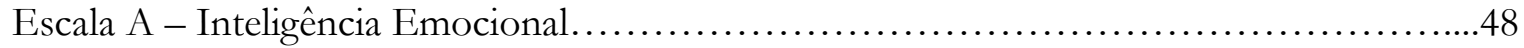

Sensibilidade.............................................................. 48

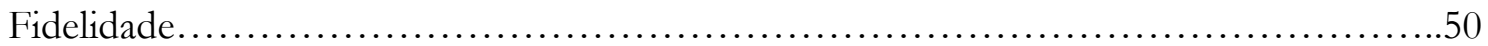

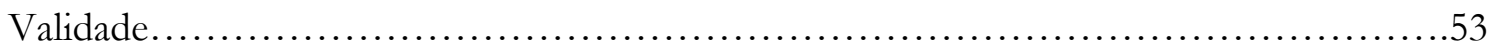

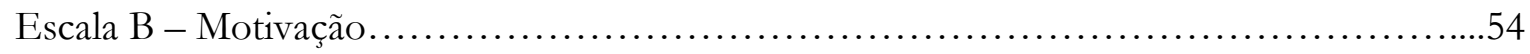

Sensibilidade............................................................ 54

Fidelidade............................................................... 55

Validade................................................................... 56

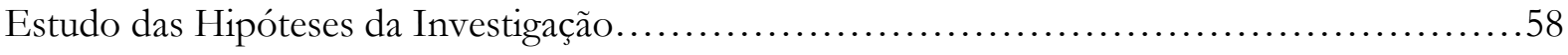

Análise de Correlação Linear.................................................... 58

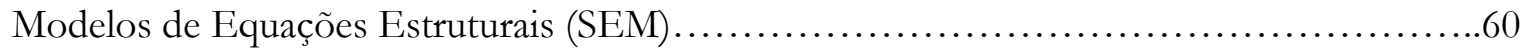

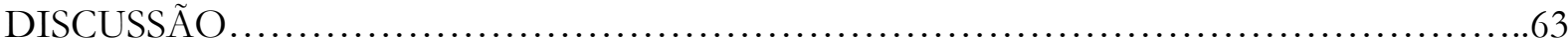

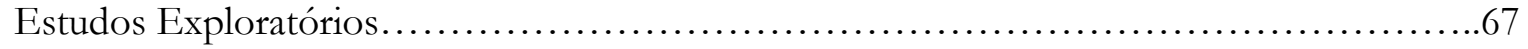

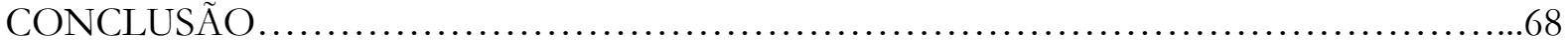

REFERÊNCIAS BIBLIOGRAFICAS ............................................. 70

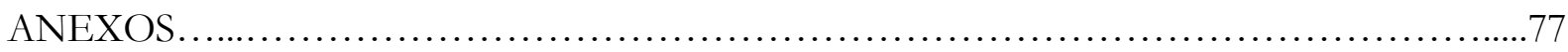

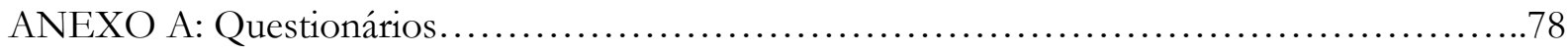

ANEXO B: Dimensões questionários............................................. 83

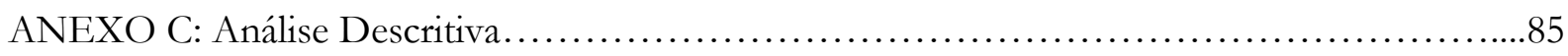

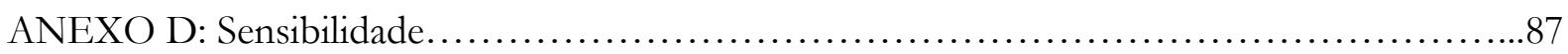

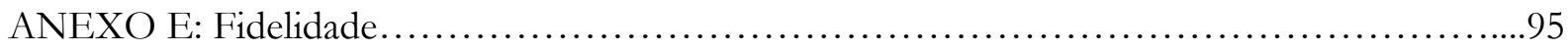

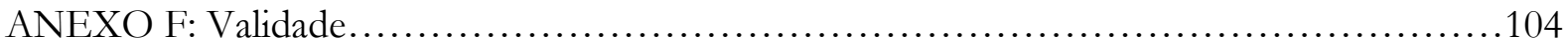

ANEXO G: Modelo de Equações Estruturais.........................................110

ANEXO H: Estudos Exploratórios.............................................. 114 
TABELA 1: Rede de Competências emocionais de acordo com o modelo de Goleman.........16

TABELA 2: Modelos de Competências e Misto............................................20

TABELA 3: Resumo das principais críticas apresentagens à Abordagem Corporativa e à Abordagem Académica e Científica da IE .......................................... 21

TABELA 4: Uma taxonomia das teorias da motivação................................... 25

TABELA 5: Médias, desvio-padrão e correlações entre variáveis para as duas amostras..........43

TABELA 6: Análise Descritiva da IE.............................................44

TABELA 7: Análise Descritiva da Motivação......................................45

TABELA 8: Níveis da Escala de Avaliação de Desempenho...............................45

TABELA 9: Análise Descritiva da Avaliação de Desempenho.............................46

TABELA 10: Valores de Kolmogorov-Smirnov (K-S) para a escala de IE....................49

TABELA 11: Parâmetros de Normalidade da IE...................................... 50

TABELA 12: Qualidade de Fidelidade de uma escala.....................................51

TABELA 13: Alpha de Cronbach para itens da Escala Total de IE..........................52

TABELA 14: Indicadores de qualidade do modelo de IE..................................53

TABELA 15: Valores de Kolmogorov-Smirnov (K-S) para a escala de Motivação...............54

TABELA 16: Parâmetros de Normalidade da Motivação...................................54

TABELA 17: Alpha de Cronbach para itens da Escala Total de Motivação.....................56

TABELA 18: Indicadores de Qualidade do Modelo de Motivação.............................57

TABELA 19: Análise descritiva e matriz dos coeficientes de correlação momento-produto de Pearson entre as variáveis principais em estudo.......................................58

TABELA 20: Matriz dos coeficientes de correlação momento-produto de Person incluindo sub-

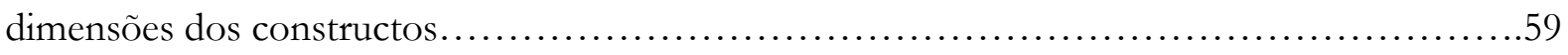

TABELA 21: Indicadores de qualidade do modelo Global..................................60 
Lista de Figuras

FIGURA 1: Modelo das Quatro Componentes da Inteligência Emocional de Mayer, Salovey e

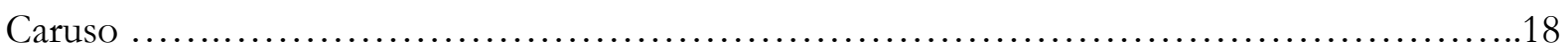

FIGURA 2: Modelo das Características da Função.....................................26

FIGURA 3: Distribuição dos participantes segundo o género..............................

FIGURA 4: Distribuição dos participantes de acordo com as classes etárias...................40

FIGURA 5: Distribuição dos participantes de acordo com o nível de escolaridade..............40

FIGURA 6: Distribuição dos participantes de acordo com a antiguidade na empresa...........41

FIGURA 7: Distribuição dos participantes de acordo com o número de anos de experiência

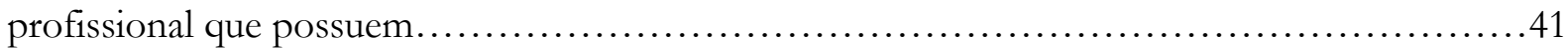

FIGURA 8: Distribuição dos participantes de acordo com o tipo de função....................42

FIGURA 9: Distribuição da IE Total.................................................. 50

FIGURA 10: Modelo para a Escala de IE ............................................. 53

FIGURA 11: Distribuição da escala de Motivação.........................................55

FIGURA 12: Modelo da escala de Motivação.......................................... 57

FIGURA 13: Modelo Global.......................................................60

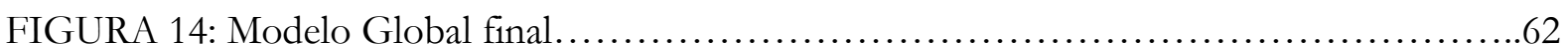




\section{RESUMO}

A inteligência emocional (IE) pode ser definida como a capacidade de utilizar a razão para compreender as emoções e realçar o pensamento. A IE inclui a aptidão de percepcionar as emoções próprias e alheias, de lhes aceder, gerar, compreender e regular (Mayer, Salovey \& Caruso, 2004).

Esta característica conduz a que, em contexto organizacional, seja considerada como um aspecto a destacar na medida em que vários autores têm relacionado esta variável com o desempenho a nível individual (e.g. Dawn \& Sojka, 2003) e colectivo (e.g. Goleman, 1998; Goleman, Boyatsis \& McKee, 2002).

Além dos factores individuais e das competências emocionais, também a motivação com as características da função poderá influenciar o desempenho indivídual. O modelo de Hackman e Oldham (1976), prevê que os indivíduos que procuram desafios, e que revelam maior interesse relativamente ao seu trabalho, estão mais satisfeitos e motivados para um bom desempenho da função.

Assim, torna-se cada vez mais importante compreender a relação entre as variáveis de IE, Motivação e Avaliação de Desempenho e a possível relação de mediação da motivação (características da função) na relação entre IE e a Avaliação de Desempenho dos colaboradores.

Os dados do presente estudo foram recolhidos através da aplicação das escalas de Rego e Fernandes (2005) para a Inteligência Emocional, da escala de Motivação, tradução do JDS (Job Diagnostic Survey) de Almeida, Faísca, Jesus (2007), e da escala de Avaliação de Desempenho utilizadas na empresa em estudo.

Os resultados obtidos não confirmam a existência de um efeito directo da IE na Avaliação de Desempenho, mas confirmam que esta relação existe quando mediada pela Motivação.

Palavras-Chave: Inteligência Emocional, Motivação e Avaliação de Desempenho. 


\begin{abstract}
The emotional intelligence (EI) may be defined as the ability to use reason to understand emotions and enhance thought. EI includes the skill to percept our own and others emotions, to access them, to generate, understand and regulate them (Mayer, Salovey \& Caruso, 2004).

In an organizational context this characteristic is considered as an aspect to headlight, in a way that various authors have connected it to individual performance (e.g. Dawn \& Sojka, 2003) and group performance (e.g. Goleman, 1998; Goleman, Boyatsis \& McKee, 2002).

In addition to the individual factors and the emotional competencies, motivation towards the role characteristics may also influence the individual performance. The Hackman e Oldham (1976) model states that individuals who seek challenges, and that show more interest towards their work, are more satisfied and motivated to a good role performance.

Therefore, it becomes more important to understand the relation between variables as EI, Motivation and Performance Development / Assessment and the possible connection of motivation measurement (role characteristics) in the relation between EI and employees Performance Development / Assessment.

The data presented on this paper was gathered through the application of Rego e Fernandes (2005) scales for Emotional Intelligence, the translated Motivation scale of (Job Diagnostic Survey) de Almeida, Faísca, Jesus (2007) and the Performance Assessment scale that is used on the Organization where this study was developed,

The final results do not confirm the existence on a direct effect of EI on Performance Assessment, but do confirm that this relation exists when is mediated by motivation.
\end{abstract}

Key-Words: Emotional Intelligence, Motivation and Job Evaluation. 


\section{INTRODUÇÃO}

Este estudo insere-se na área da Psicologia Organizacional e tem como propósito estudar as relações entre as variáveis Inteligência Emocional (IE), Motivação e Avaliação de Desempenho e também analisar o possível efeito mediador da Motivação na relação entre Inteligência Emocional e Avaliação de Desempenho dos colaboradores de uma Multinacional do sector Financeiro.

Não obstante os anos 90 terem sido conhecidos pela "Década do Cérebro", nos últimos anos, observou-se um crescente interesse pelas emoções e pela Inteligência Emocional, em particular os autores Goleman (1998), Salovey, Mayer e Caruso (2002).

Em contexto organizacional a IE tem sido apontada como uma competência importante, na medida em que vários autores têm relacionado esta variável com o desempenho a nível individual (e.g. Dawn \& Sojka 2003).

Também a motivação tem sido apontada como um conceito central em comportamento organizacional (e.g. Baron, 1991). Os teóricos, investigadores e gestores aumentaram o seu interesse neste conceito desde que este começou a ser considerado como uma das variáveis que influenciam o desempenho individual.

O desempenho dos colaboradores nas empresas e as variáveis que o influenciam, têm sido alvo de inúmeros estudos no âmbito do Comportamento Organizacional e Gestão de Recursos Humanos mostrando-se assim cada vez mais importantes, considerando a influência que o desempenho individual tem nos resultados da organização tal como comprovam os trabalhos elaborados por vários autores (e.g. Schmidt, Ones \& Hunter, 1992; Hunter \& Schmidt, 1996; Welbourne, Johnson \& Erez, 1998.)

Neste sentido recorreu-se à aplicação de um questionário, com duas escalas: uma escala de Inteligência Emocional e outra de Motivação, aos colaboradores de uma mesma organização, e foram também recolhidos os resultados das notas de Avaliação de Desempenho dos colaboradores da empresa em estudo, referentes ao ano de 2008.

A importância deste estudo pode resumir-se em três pontos fundamentais:

(1) Apesar de já haver algumas investigações realizadas sobre as temáticas abordadas neste trabalho, são ainda insuficientes os estudos, o que leva a não haver consenso dos investigadores nestas matérias, justificando-se por isso o seu aprofundamento. 
(2) Os estudos sobre IE tem sido desenvolvidos em contextos específicos de vendas, sendo por isso este estudo inovador por abarcar uma amostra com uma maior transversalidade de funções, abarcando funções de back-office e funções de contacto directo com o cliente.

(3) o terceiro e último fundamento para a presente pesquisa relaciona-se com o contexto geral, neste caso o português, onde são necessárias mais investigações não apenas sobre IE, mas também sobre todos os aspectos atrás delineados, permitindo assim reforçar que não é possível basear a gestão das pessoas em critérios e competências de ordem puramente racional, devendo os gestores dar cada vez mais importância a variáveis emocionais e à influência que estas têm no desempenho dos colaboradores, à melhoria das características da função que cada indivíduo desempenha e à forma como é avaliado o desempenho nas organizações.

Em seguida, será apresentada uma revisão da literatura sobre Inteligência Emocional, Motivação e Avaliação de Desempenho, que engloba uma visão dos vários modelos que abordam estas temáticas. 
Inteligência Emocional

Conhecer os outros e conbecer-se a si próprio, nenbum perigo em 100 batalhas.

Não conbecer o outro e conhecer-se a si próprio, uma vitória para cada derrota. Não conbecer o outro e não se conhecer a si próprio, derrota certa em todas as batalhas.

Sun Tzu, A Arte da Guerra

\section{Pertinência do Estudo da Inteligência Emocional}

Segundo Dantzer e Moal a emoção pode ser definida como “(...) um estado particular de um organismo que sobrevem em condições bem definidas (uma situação dita emocional) acompanhado de uma experiência subjectiva e de manisfestações viscerais (...)”. Outros autores, como Mayer, Caruso e Salovey (2000), definem as emoções como eventos internos que coordenam muitos subsistemas psicológicos, incluíndo respostas fisiológicas, cognições e o estado de alerta; surgem, tipicamente, como resposta às mudanças de relacionamentos do indivíduo.

De uma forma geral, pode dizer-se que as emoções e a inteligência não são mutuamente exclusivas. Foi através de um artigo de McClelland "Testing for competence rather than intelligence", de 1973 (cit. por Goleman, 1998), que se iniciou a reviravolta no estudo sobre inteligência. Neste artigo, o autor defende que a tradicional aptidão académica, as habilitações literárias e os diplomas não podem, simplesmente, antecipar o bom desempenho de uma pessoa. McClelland propôs a ideia de que um conjunto de competências, incluindo a empatia, a autodisciplina e a iniciativa, distinguia aqueles que seriam os mais bem sucedidos.

Segundo Daniel Goleman (1998) "as emoções são sentimentos que se expressam em impulsos e numa vasta gama de intensidade, gerando ideias, condutas, acções e reacções. Equilibradas e bem-conduzidas transformam-se em sentimentos elevados, sublimados, tornandose, assim - virtudes". Este autor procura demonstrar que não só a razão influencia os nossos actos, mas que a emoção também é responsável pelas nossas respostas e tem grande poder sobre as pessoas. "Cognição, emoção, resposta" é a tríade conceptual que serve como base explicativa do comportamento humano e do respectivo processo de interacção. Esta tríade funciona circularmente, ou seja, a pessoa tem uma cognição, enquanto processa mentalmente a cognição 
sente uma emoção e em função do tipo de emoção sentida gera uma resposta. Por isso, as emoções ditam a qualidade da resposta e do processo de relação com os outros.

De acordo com Goleman (1998), competências emocionais são consideradas importantes para que uma pessoa alcance seus objectivos, seja feliz e obtenha sucesso na vida. De entre algumas são citadas o controle do temperamento, adaptabilidade, persistência, amizade, respeito, amabilidade e empatia.

Assim, a IE tornou-se num dos conceitos psicológicos mais populares e recentes desta última década. A curiosidade e absorção pela sociedade sobre este tema podem estar relacionadas com a suposição de que as pessoas com melhor controle das próprias emoções são aquelas que provavelmente são mais bem sucedidas no mercado de trabalho e apresentam melhor qualidade de vida. Goleman (2000) afirmou que “(...) quando calculei o ratio das competências técnicas, do QI e da IE, enquanto ingredientes para um desempenho excelente, a IE provou ser duas vezes mais importante para trabalhar em todos os níveis (...)".

O estudo sobre IE iniciou-se em 1920 quando Thorndike propôs um constructo muito semelhante ao de IE, que ele designou por Inteligência Social que se referia à capacidade de perceber e gerir relações interpessoais. Mayer e Salovey foram os primeiros que usaram o termo IE e por isso argumentam que "a inteligência social está relacionada com um constructo mais global - a IE - que comprime um grupo de competências que são distintas das tradicionais dimensões verbais-proposicionais/performance espacial da inteligência” (cit por Mayer, Salovey e Caruso, 1999).

Por outro lado, o termo IE apresenta estreita similitude com conceitos como "inteligências inter e intrapessoal" que podem ser descritos como:

A inteligência interpessoal está baseada numa capacidade (...) de perceber distinções entre os outros; em especial, (...) estados de ânimo, temperamentos, motivações e intenções (...). Essa capacidade aparece numa forma altamente sofisticada em líderes religiosos ou politicos, professores, terapeutas e pais" [p.27]... [A inteligência intrapessoal refere-se a] aspectos internos de uma pessoa: o acesso ao sentimento da própria vida, à gama das próprias emoções, à capacidade de discriminar essas emoções e eventualmente rotulá-las e utilizá-las como uma maneira de entender e orientar o próprio comportamento(...) (Gardner, 1995, p.28).'

As pessoas que possuem bases genéticas apropriadas desenvolvem a sua IE de forma superior, com base no que a natureza lhes deu. Outras precisam de tempo, esforço e prática repetida para alcançar o nível de IE em que suas competências e versatilidade lhes dêem a flexibilidade de lidar com situações sempre diferentes. Desta forma, a IE pode ser aprendida e assim, desenvolver a IE está ao alcance de qualquer um.

\footnotetext{
${ }^{1}$ Gardner, H. (1995). Inteligências Multiplas. A Teoria na prática. Porto Alegre: Artes Médicas.
} 
O tema da Inteligência Emocional começa a ser cada vez mais importante para o sucesso das empresas. Por isso, deixou de ser possível basear a gestão apenas em critérios e competências de ordem puramente racional. Actualmente, é fundamental que os gestores saibam reconhecer também o lado emocional dos seus colaboradores no local de trabalho.

Assim, o êxito, no novo cenário empresarial, exige sensibilidade, grande intuição e um vasto conjunto de competências emocionais, para que no presente e no futuro consigam transformar ideias e emoções em produtos.

Face a estes resultados, Claus Moller, citado pelo jornal «Expresso», afirma que «as empresas serão forçadas a concentrarem-se nas emoções, porque o factor remuneratório não é suficiente para reter as pessoas e motivá-las a dar o seu melhor», e acrescenta que «há que incluir uma remuneração emocional»

\section{Abordagens da IE}

Van Rooy e Viswesvaran (2003) foram dois autores que conceptualizaram a IE como "um conjunto de competências (verbais e não-verbais) que levam uma pessoa a gerar, reconhecer, expressar, compreender e avaliar as suas e as emoções dos outros, no sentido de guiarem o seu pensamento e as suas acções que lidam com o sucesso, com as exigências e pressões do meio ambiente" (p.2). Mas a definição que é mais destacada na literatura é a de Mayer e Salovey (1997) em que estes definem a IE como a capacidade para avaliar, expressar e regular as emoções (no próprio e nos outros) e a capacidade para as utilizar (resolução de problemas).

Apesar de todas estas definições serem válidas, com o avanço do estudo sobre IE, os investigadores têm necessidade de reformular, constantemente, as suas próprias definições sobre esta temática. Apesar das constantes reformulações, as novas definições não são contraditórias mas sim complementares das definições já existentes.

Nesta revisão teórica será feita uma análise sobre as duas principais correntes da IE.

\section{Abordagem Corporativa da IE}

A primeira abordagem foi popularizada por Goleman e é designada por "Abordagem Corporativa da IE". Segundo esta abordagem, a definição de IE considera um conjunto de capacidades não cognitivas, competências e habilidades. 
Segundo Goleman (1998), a IE determina o potencial de aprendizagem de aptidões práticas que se baseiam em cinco elementos:

- Autoconsciência, capacidade de reconhecer e compreender as próprias emoções, sensações e estados de humor bem como o seu efeito nos outros,

- Motivação, a paixão pelo trabalho por razões que vão além do dinheiro ou do status,

- Autodomínio, a capacidade de controlar ou redireccionar impulsos e estados de humor negativos, a propensão de pensar antes de agir,

- Empatia, a capacidade de compreender o que vai além do que os outros dizem, o que vai além da "máscara emocional" dos outros,

- Talento nas relações, capacidade de gerir relações interpessoais e construir redes de contactos.

Goleman, Boyatzis e McKee (2002) sugeriram a redução dos cinco elementos primordiais da investigação de Goleman a quatro domínios principais: Autoconsciência, Autodomínio, Consciência Social e Gestão das Relações, em que cada um deles proporciona um conjunto de aptidões fundamentais para uma elevada IE, que é também designada por rede de competências emocionais (Tabela 1).

Tabela 1 - Rede de Competências emocionais de acordo com o Modelo de Goleman

\begin{tabular}{lll}
\hline & Self & Outro \\
& Competências Pessoais & Competências Sociais \\
\hline \multirow{3}{*}{ Reconhecimento } & Autoconsciência & Consciência Social \\
& Autoconsciência Emocional & Empatia \\
& Auto-Avaliação & Consciência Organizacional \\
& Autoconfiança & Orientação para o serviço \\
& Auto-Domínio & Gestão das Relações \\
Auto-Domínio & Desenvolvimento de outros \\
& Transparência & Liderança \\
Adaptabilidade & Influência \\
& Orientação para os resultados & Catalizador de mudança \\
& Iniciativa & Gestão de conflitos \\
& Optimismo & Trabalho de equipa e colaboração \\
\hline
\end{tabular}

Fonte: Emmerling e Goleman, 2003 
O autor refere que para possuir uma capacidade em termos de IE é necessário manisfestar competência em qualquer um dos quatro domínios mencionados apesar desta condição não ser suficiente para se ser bem sucedido. Goleman sugere que cada um dos quatros domínios tem como base mecanismos neurológicos específicos que permitem distinguir os domínios uns dos outros e, ao mesmo tempo, todos eles podem ser distinguidos de capacidades cognitivas (Goleman, 2000). O autor desta corrente corporativa ainda refere que existe uma IE, que subjaz às competências e capacidades cognitivas puras, como a inteligência. Esta definição foi fortemente criticada pela abordagem cientifica devido ao facto de o autor, na sua definição de IE, incluir uma combinação de traços de personalidade, caracteristicas emocionais, capacidades e motivações. Outra das críticas feitas pela corrente cientifica, relaciona-se com o facto de Goleman sugerir que as competências emocionais podem ser aprendidas, ou seja, segundo este autor, as competências emocionais são competências de trabalho que podem ser aprendidas quando um indivíduo procura ser bem sucedido em termos profissionais ou quando existe o objectivo destas competências causarem impacto positivo na vida das pessoas.

\section{Abordagem Académica e Cientifica da IE}

A segunda abordagem da IE é designada por Abordagem Académica e Científica da IE. Mayer, Solavey e Caruso são os autores desta abordagem e referem que a IE é uma forma de inteligência que processa e benefícia das emoções e por isso, o conceito engloba capacidades, habilidades e faculdades mentais. Segundo estes autores, as emoções possuem a capacidade de se desenvolver em padrões predizíveis interrelacionados com situações sociais e acontecimentos correntes mais ou menos complexos. Assim, estes autores referem que a inteligência é necessária para a pessoa perceber as emoções que decorrem desses acontecimentos (Barata, 2004).

Mayer, Solavey e Caruso definem a IE como “(...) a capacidade que as pessoas têm de monitorizar os seus sentimentos e emoções, bem como os sentimentos e emoções dos outros, a capacidade para diferenciar as emoções umas das outras, e a capacidade para usar essa informação para guiar o pensamento e acções (...)" (Goldsworthy, 2000 cit. por Barata, 2004). Então, segundo este modelo existem quatro componentes ou conjuntos de capacidades mentais:

1. percepcionar, avaliar e exprimir emoções no self e nos outros;

2. facilitar em termos emocionais o pensamento;

3. compreender e analisar emoções;

4. regular e gerir emoções para adaptação e promoção do desenvolvimento intelectual e emocional. 
Figura 1: Modelo das Quatro Componentes da Inteligência Emocional de Mayer, Salovey e Caruso (Adaptado de Mayer et al., 1999, p.269).

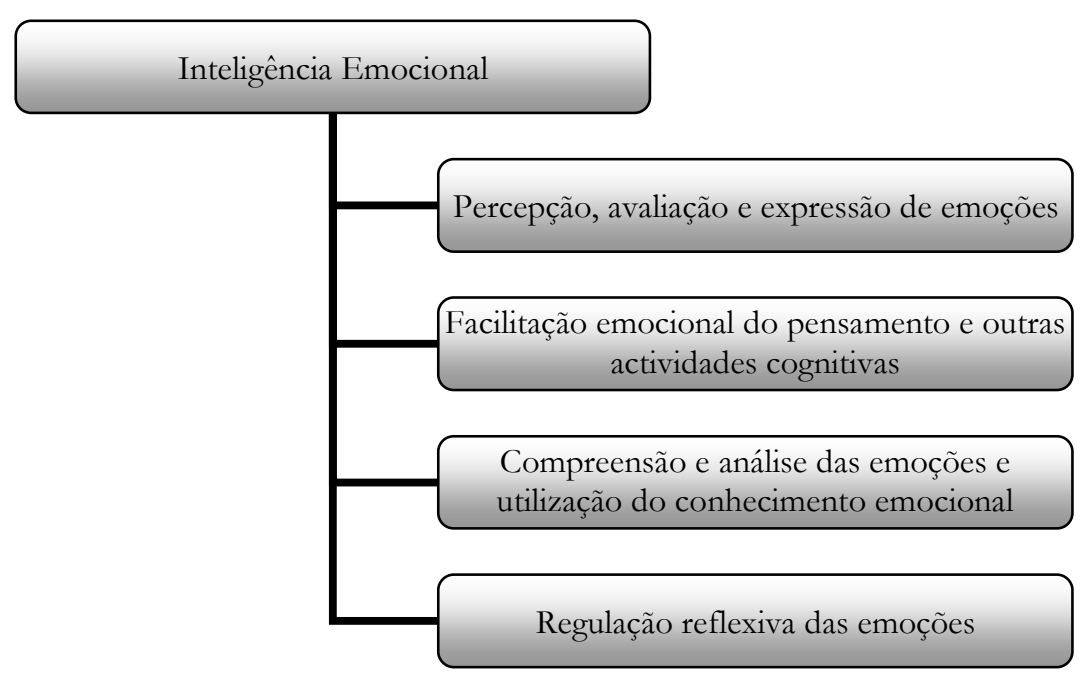

No primeiro componente apontado por Mayer et al. (1999) estão contempladas as competências que permitem ao indivíduo percepcionar, avaliar e expressar emoções. Nestas capacidades estão a identificação das emoções do próprio e dos outros, a expressão das próprias emoções e a discriminação das emoções nos outros, ou seja, envolve o reconhecimento e integração de informação verbal e não-verbal do sistema emocional (Caruso, Mayer \& Salovey, 2002).

No segundo componente, o indivíduo poderá utilizar as suas emoções no sentido de facilitar o seu pensamento, empregando as emoções, no sentido de auxiliar o julgamento, reconhecer as alterações de estado de espírito que podem levar à consideração de pontos de vista alternativos e compreender que uma mudança num estado emocional ou perspectiva pode levar a diferentes formas de resolução de problemas.

De acordo com Caruso et al. (2002), a pessoa que utilize o terceiro componente tem uma grande capacidade de perceber importantes aspectos da natureza humana e das relações interpessoais em virtude de poderem ser utilizadas competências como o denominar/atribuir um nome e a distinção entre emoções, compreensão de misturas de sentimentos e formulação de regras acerca dos próprios sentimentos.

O quarto e último componente apontado pelos autores, está relacionado com a capacidade de regular as emoções no sentido de um objectivo social, ou seja, capacidades de o indivíduo de forma selectiva, ligar-se ou desligar-se das emoções, de as monitorizar e as gerir em si próprio e nos outros. 
A definição de IE destes autores preocupa-se unicamente em verificar se ela é, ou não, uma verdadeira forma de inteligência e, nesse sentido, focaliza-se exclusivamente nas capacidades mentais ou cognitivas. Esta é a grande diferença entre estas duas abordagens. Além disto, contrariamente à abordagem corporativa, Mayer, Salovey e Caruso referem que a IE não está directamente relacionada com o desempenho pessoal e profissional, estando sim, segundos estes autores, relacionada com o pensamento, raciocínio e processamento da informação.

As investigações destes autores permitiram-lhes explorar um amplo conjunto de possibilidades e eventuais implicações sobre as consequências da utilização da IE na vida prática dos sujeitos. Segundo Barata (2004) os autores sugerem mesmo que o reconhecimento da IE pode ter efeitos positivos para a vida em sociedade uma vez que auxilia as pessoas a tornarem-se mais conscientes.

Resumindo, podemos observar a distinção que fizeram Mayer e Salovey (1997) entre o Modelo de Competências e o Modelo Misto.

O Modelo de Competências é, segundo estes autores, centrado na aptidão do processamento de informação afectiva enquanto que o modelo misto conceptualiza a IE como um constructo diverso que inclui aspectos de personalidade bem como capacidades de perceber, assimilar, compreender e gerir emoções. $\mathrm{O}$ modelo misto inclui em si factores motivacionais e disposições afectivas como empatia, assertividade, etc. Os modelos mistos (especialmente o de Goleman) são alvo de maior popularidade, ao passo que o modelo de competências colhe maior receptividade nos meios académicos e científicos (Cunha, Rego, Cunha \& Cardoso, 2004).

Apresenta-se em seguida, a Tabela 2, onde são delineados os pontos fortes e fracos de ambos os modelos referidos. 
Tabela 2- Modelos de competências e misto - pontes fortes e limitações

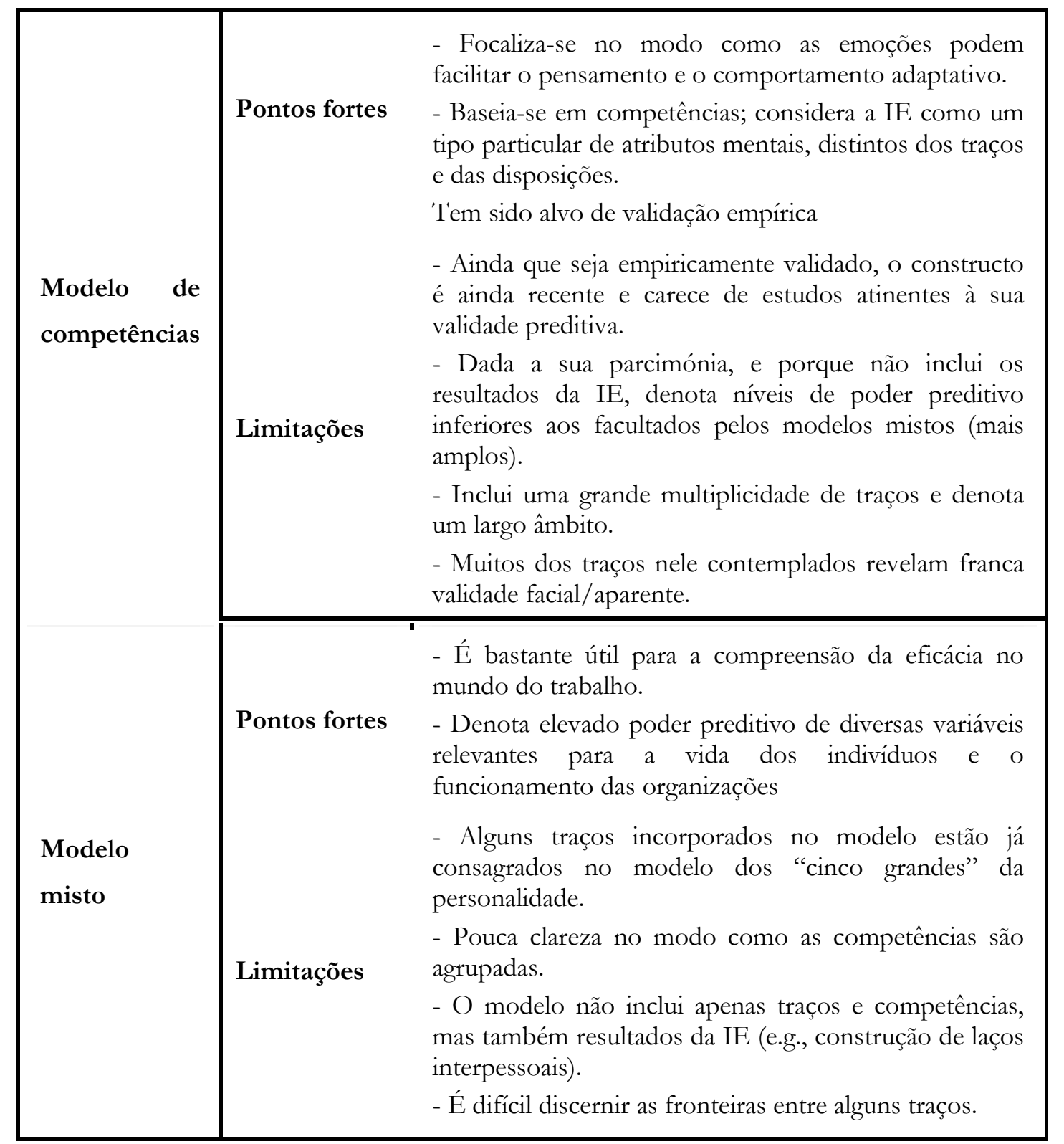

Fonte: Cunha et al., 2004

O instrumento de medida utilizado baseia-se no quadro teórico dos modelos mistos, por duas razões fundamentais: (1) os itens em que assenta a validação do constructo foram recolhidos em literatura diversa - tanto ao que refere ao modelo de competências mentais quanto ao que concerne a diversos modelos mistos; (2) as dimensões emergentes dos estudo factorial/dimensional contemplam, para além das competências mentais, outros traços e competências (e.g., empatia). (Rego \& Fernandes, 2005) 


\section{Críticas à IE}

Apesar de ser um conceito ainda pouco estudado, existem já muitos trabalhos que criticam este conceito bem como muitos que o defendem e que expõem os vários modelos que se inserem na IE.

Uma das prinicipais críticas que se podem fazer ao conjunto de teorias da emoção, tem a ver com o facto de não se ter chegado a nenhum consenso quanto ao número e tipo de emoções que existem. Nos últimos anos do séc. XX, os cientistas - tanto do lado das ciências cognitivas, como do lado da neurociência - têm vindo a esbater a oposição emoção-razão, e a emoção passou a fazer parte integrante dos processos de raciocínio e tomada de decisão.

Segundo Zeidner, Roberts e Matthwes (2002), as críticas ao conceito de IE reforçam sempre os aspectos de que a IE é um conceito pouco estudado, controverso, sobre o qual não se reúne consenso e que apresenta problemas em termos de medição.

Considerando a indefinição de termos e conceitos, várias críticas foram apresentadas às duas principais abordagens da IE que resumimos de seguida na Tabela 3

Tabela 3: Resumo das principais críticas apresentadas à Abordagem Corporativa e a Abordagem Académica e Cientifica da IE

\begin{tabular}{|c|c|}
\hline ABORDAGEM CORPORATIVA & ABORDAGEM ACADÉMICA E CIENTIFICA \\
\hline $\begin{array}{l}\text { - Contradição de Termos: Goleman elaborou a IE } \\
\text { como um constructo com base em competências não } \\
\text { cognitivas, relacionando-as com inteligência, definindo } \\
\text { assim uma inteligência não cognitiva, o que significa, } \\
\text { segundo a comunidade cientifica “(...) uma contradição } \\
\text { de termos (...)" (Goldsworthy, 2000; Hein, 2000). } \\
\text { • Sobreposição com os modelos de } \\
\text { personalidade: se uma pessoa tem um determinado } \\
\text { comportamento e este é assumido como um traço de } \\
\text { personalidade predominante, então não se pode } \\
\text { considerar a IE como uma inteligência (Mayer et al., } \\
\text { 2000). }\end{array}$ & $\begin{array}{l}\text { - Inato, Genético ou Ambos? Uma crítica } \\
\text { apontada a esta teoria prende-se com o facto de ainda } \\
\text { não ter sido estudado se a IE é um factor inato, se é } \\
\text { genético, ou ambos (Hein, 2000). E, ainda, em caso } \\
\text { positivo, quando é que pode ser aprendida e/ou } \\
\text { desenvolvida e em que proporções. } \\
\text { - Competências Aprendidas ou inatas? Uma das } \\
\text { competências identificadas por Mayer, Salovey e Caruso } \\
\text { foi a Gestão Emocional a qual é facilmente aceite pelo } \\
\text { público porque a sociedade fomenta os indíviduos a } \\
\text { gerirem e a regularem as suas emoções, ou seja, as } \\
\text { pessoas praticam um modelo de auto-gestão e auto- } \\
\text { regulação mesmo antes de compreender as suas } \\
\text { emoções (Goldsworthy, 2000). }\end{array}$ \\
\hline
\end{tabular}


- Conceito Incerto: A análise de Goleman não descreve como distinguir a IE de outros traços de personalidade e competências que possam influenciar a regulação e o reconhecimento das emoções permanecendo o termo de IE como um conceito incerto (Zeidner et al 2002).

- Falta de Evidências Empíricas: afirmações de Goleman (2000) como "a IE prognostica QI" e "IE é duas vezes mais importante do que o QI" levam a crítica a salientar que estas afirmações apresentam um carácter meramente especulativo e que não existem ainda evidências científicas sérias para fazer estas afirmações.

- Definição de IE Extensa e Abrangente: a definição de Goleman inclui uma combinação de caracteristicas emocionais que parecem estender-se para além da definição mais liberal de inteligência e parece estar perto da concepção de quase tudo que interesse para além do quociente de inteligência (...)" (Sterneberg, 2000)
Medição: Para além de poder haver numa pessoa uma capacidade em potencial, não desenvolvida, tembém pode haver uma competência em potencial, já desenvolvida, mas que não possa no entanto ser medida, quantificada ou demonstrada. A crítica refere que não existe actualmente nenhuma forma de medir o potencial puro das pessoas (Hein, 2000) e, por isso, os testes desenvolvidos por Mayer, Salovey e Caruso medem somente as capacidades efectivamente demonstradas e nunca o potencial existente.

\section{- Quantificação e Medição de Competências} específicas: relativamente à quantificação e medição das competências definidas por Mayer, Salovey e Caruso - facilitação emocional de pensamento e gestão emocional - a crítica refere que é dificil medir tais competências através de testes (Hein, 2000). As competências dificilmente são definidas através de testes psicométricos e, embora possam de alguma forma aferilas, não o farão de uma forma que nos indique as capacidades em situações da vida real, em situações críticas ou, ainda, em situações de stress.

- Generalização da IE na Sociedade: é sugerido pelos autores desta abordagem que o desenvolvimento da IE pode dar origem a uma sociedade onde as pessoas conseguem intergrar a razão com a emoção, com o objectivo de vivem com mais harmonia, sendo esta uma visão com a qual os críticos discordam por “(...) não se dever antecipar cenários ou concepções do que é ou náo é politicamente correcto “(..) (Mayer, Salovey \& Caruso, cit in Seternberg, 2000) para a sociedade e para a vida em geral.

- IE e Desempenho: No seguimento da afirmação de Goleman (1998) de que “(...) a IE prediz cerca de $80 \%$ do sucesso de uma pessoa na vida (...)", Graves (cit. Por Hein, 2000) escreveu que “(...) contrariamente a algumas descobertas, a IE não parece ultrapassar as capacidades cognitivas em termos de prognóstico de desempenho. Parece que a IE e as capacidades cognitivas desempenham papéis igualmente importantes $(\ldots)^{\prime \prime}$. 
Síntese

Apesar das inúmeras teorias sobre a IE, ainda não foi possível chegar a conclusões definitivas. Isto deve-se ao facto das pesquisas terem vindo a ser conduzidas de uma forma díspar e, em direcções opostas. Desta forma, as características da IE são actualmente equacionadas em posições diametralmente opostas, consoante estamos a falar da corrente corporativa ou da corrente científica.

Assim, pelos motivos explicitados na revisão de literatura, a abordagem corporativa não tem interesse em estudar quais são as raízes do conceito, mas explora as competências associadas ao mesmo, focando-se nos resultados positivos do desenvolvimento da IE, para a eficácia das organizações. Por sua vez a abordagem científica, procura estudar o conceito para perceber se estamos perante uma nova forma de inteligência.

A grande diferença entre estas duas grandes abordagens é não só a definição do conceito mas também nas técnicas de aferição daquilo que é, para cada uma delas, a IE.

Ambas as abordagens também têm objectivos diferentes. A abordagem corporativa tem como objectivo determinar as competências que os indíviduos conseguem manipular, partindo do pressuposto de que uma utilização racional dessas competências tem como resultado um nível mais elevado de IE. Por outro lado, o objectivo da abordagem científica é determinar as capacidades inteligentes dos indivíduos na regulação e controlo das emoções.

Independentemente das críticas já feitas às diferentes abordagens e as divergências que existem entre ambas, a IE parece ser um constructo com potencial teórico, podendo inferir-se que, um indíviduo que possua uma elevada IE, não garante que este adquira as competências emocionais que são importantes para o seu trabalho mas implica que o mesmo possua um excelente potencial para as desenvolver.

As pesquisas já demonstraram que os sujeitos emocionalmente inteligentes percepcionam e avaliam de forma correcta os seus estados emocionais, sabem como e quando expressar as suas emocções e conseguem regular e gerir os seus estados de espírito, sentimentos e emoções. Assim, a IE assume um papel cada vez mais importante na explicação dos diversos fenómenos psicológicos e de gestão empresarial (Law, Wong \& Song, 2004) e para a compreensão dos comportamentos dos indivíduos, não só em situações das suas vidas pessoais mas também ao nível profissional (Cunha et al., 2004). 


\begin{abstract}
Motivação
"O segredo da existência humana consiste não somente em viver, mas ainda encontrar o motivo para viver" Fiódor Dostoiévski
\end{abstract}

\title{
Abordagem geral
}

A motivação tem sido frequentemente apresentada como o conceito central em comportamento organizacional. (e.g. Baron, 1991).

A motivação no trabalho começou a reunir o interesse dos teóricos, investigadores e gestores devido à sua relação com a produtividade. Duas características têm sido repetidamente apresentadas como relevantes para a melhoria da produtividade através das pessoas: as capacidades indivíduais e a motivação.

É bastante difícil definir o conceito de motivação, por se tratar de um constructo invisível, de utilização generalizada nas ciências humanas e abordável segundo uma grande multiplicidade de perspectivas. Uma possível definição de motivação para o trabalho é a de Pinder (1998) em que este conceito é definido como “o conjunto de forças energéticas que têm origem quer no indíviduo quer fora dele, e que moldam o comportamento de trabalho, determinando a sua forma, direcção, intensidade e duração.

George e Jones (1999) definiram a motivação como "As forças psicológicas internas de um indíviduo que determinam a direcção do seu comportamento, o seu nível de esforço e a sua persistência face aos obstáculos”.

Segundo Cunha et al. (2004), não existe uma grande variação entre as várias definições de motivação, sendo que todas elas incluem elementos como: estimulação que é definida pelas forças energéticas que são responsáveis pelo despoletar do comportamento; a acção e esforço que se traduz no comportamento observado; o movimento e persistência sendo estes definidos pelo prolongamento no tempo do comportamento; e por fim um elemento de recompensa, representando este um reforço das acções anteriores. Os mesmos autores referem ainda que a motivação poderá ser dividida em motivação intrínseca e extrínseca. A primeira refere-se aos comportamentos de trabalho que são estímulados pelo entusiasmo que o trabalho em si mesmo suscita naquele que o executa. Comportamentos extrínsecamente motivados são aqueles que as 
pessoas levam a cabo com finalidade de obter alguma recompensa material ou social, ou para evitar alguma forma de punição (Cunha et al., 2004).

Teorias da Motivação

Segundo Cunha et al. (2004) uma das classificações de maior valor organizador da diversidade de abordagens e teorias da motivação cruza dois critérios: O primeiro distingue teorias de conteúdo e teorias de processo. O segundo discerne entre teorias gerais sobre a motivação humana e as teorias específicas. Esta organização está exposta no Tabela 4.

Tabela 4: Uma taxonomia das teorias da motivação.

\begin{tabular}{l|l|l}
\hline & \multicolumn{1}{|c}{ Teorias Gerais } & \multicolumn{1}{c}{ Teorias Organizacionais } \\
\hline \multirow{3}{*}{ Teorias de Conteúdo } & - Hierarquia das Necessidades & - Teoria Bifactorial \\
& - Teoria ERG & - Teoria das Características da \\
& - Teoria dos Motivos & Função \\
Teorias de Processo & - Teoria da Equidade & - Definição de objectivos \\
& - ModCO & - Teoria das Expectativas \\
& - Teoria da Avaliação Cognitiva \\
\hline
\end{tabular}

Segundo Cunha et al. (2004), as teorias de conteúdo procuram explicar a motivação através da análise dos motivadores: “O que motiva as pessoas?” Por outro lado, as teorias de processo analisam a motivação de uma forma mais dinâmica, procurando sobretudo resposta para a questão: "Como se desenrola o comportamento motivado?"

Os mesmos autores definiram as teorias gerais como aquelas que se referem a aspirações genéricas dos seres humanos, ou seja, que não se centram exclusivamente no trabalho e no comportamento organizacional como acontece nas teorias organizacionais (Cunha et al., 2004).

Não tendo este trabalho o íntuito de fazer uma descrição exaustiva das teorias da motivação existentes, iremos focar-nos na Teoria das Características da Função que se insere dentro das teorias organizacionais e de conteúdo e na qual se baseia a escala de motivação utilizada neste trabalho. 
Teoria das Características da Função

Segundo Parker e Wall (2001) as características do trabalho têm sido apontadas como uma das principais causas de (des)motivação. Estudos já efectuados já demonstraram que estas características estão na base da motivação intrínseca (Houkes, Janssen, Jonge \& Nijhuis, 2001).

Segundo Hackman e Oldham (1980), a motivação no trabalho resulta também das características do trabalho que o indivíduo executa. Com base neste pressuposto, os autores consideram ser possível desenvolver formas ideiais de organização do trabalho, nomeadamente através do incremento da variedade de aptidões requeridas pelo trabalho, da identidade e do significado das tarefas, da autonomia da função e ainda do feedback das tarefas (Ferreira, Neves \& Caetano, 2001). Uma vez postas em prática estas melhorias no trabalho, levarão a um aumento da motivação dos colaboradores, tendo sido esta a razão que levou os autores a desenvolver o modelo das características da função (Hackman \& Oldham, 1976).

Conforme se pode observar na figura 2, as características centrais do trabalho (variedade de aptidões, identidade da tarefa, significado da tarefa, autonomia na função e feedback) irão influenciar os estados psicológicos dos indivíduos que, por sua vez, irão contribuir para o desempenho, para a motivação, para a satisfação no trabalho e para o turnover.

Figura 2: Modelo das Características da função

\begin{tabular}{|c|c|c|l}
\hline $\begin{array}{c}\text { DIMENSÕES } \\
\text { DO } \\
\text { TRABALHO }\end{array}$ & $\begin{array}{c}\text { ESTADOS PSICOLÓGICOS } \\
\text { CRÍTICOS }\end{array}$ & \\
RESULTADOS
\end{tabular}
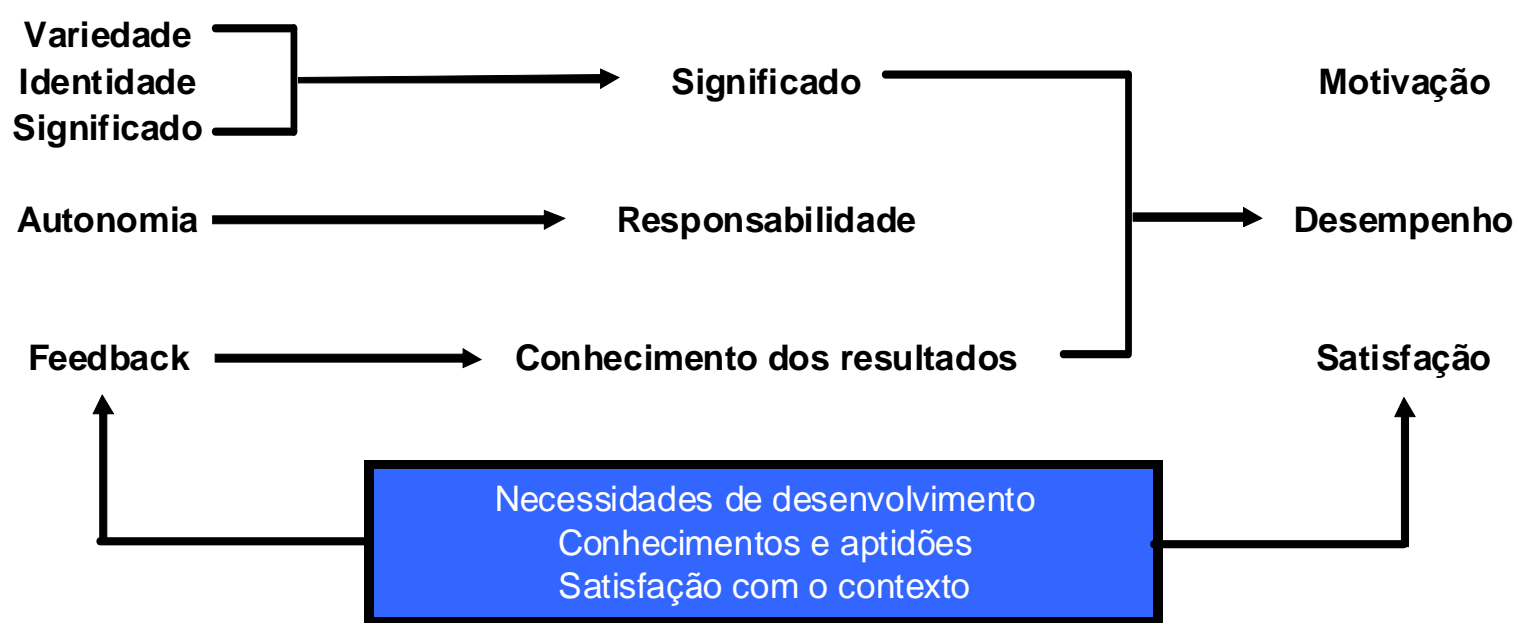

Cunha et al. (2004) definiram estes conceitos para uma melhor compreensão e contextualização dos mesmos dentro deste modelo. Assim, a variedade refere-se ao grau em que a função exige o recurso a competências, actividades e conhecimentos diversificados; a Identidade refere-se ao grau em que a função requer a execução de uma unidade de trabalho 
identificável, i.e., com príncipio e fim, e que origina um resultado visível; O significado da tarefa diz respeito ao impacto do trabalho nas vidas dos outros, seja dentro ou fora da organização. Quanto maior esse impacto, maior o significado do trabalho; A autonomia é definida como o nível de independência no planeamento do trabalho e na respectiva forma de execução; por fim, o feedback diz respeito à quantidade e qualidade da informação sobre o progresso do indivíduo na execução do trabalho e os níveis de desempenho alcançados.

Segundo Ferreira et al. (2001), existem 3 estados psicológicos distintos que podem ser induzidos pelas diferentes características centrais do trabalho. Assim, a variedade, a identidade e o significado da tarefa influenciam o significado que o colaborador vai atribuir ao seu trabalho, sendo este último o grau em que a pessoa considera o seu trabalho valioso e digno de ser feito; a autonomia na função irá influenciar a responsabilidade pessoal do indivíduo pelo trabalho que executa, dizendo esta respeito ao grau em que o indivíduo se sente pessoalmente responsável pelos resultados do trabalho; e o feedback reforça o conhecimento acerca dos resultados do trabalho, sendo assim possível que o indivíduo perceba quão eficazmente está a realizar o trabalho.

No seu modelo, Hackman e Oldham (1980), consideraram também uma variável intraindividual mediadora desta relação entre as características do trabalho e os resultados finais. Assim, estes autores consideraram que a intervenção ao nível das características e conteúdo do trabalho terá tanto mais impacte na motivação, desempenho e satisfação quanto maior for a necessidade de desenvolvimento dos colaboradores. Pessoas com maior necessidade de desenvolvimento profissional, respondem mais positivamente à presença das cinco características da função, obtendo assim níveis de produtividade mais elevados (Graen, Scandura \& Graen, 1986).

Cunha et al. (2004), também referiram que será importante considerar outras variáveis intermédias, tais como os conhecimentos e aptidões que o indivíduo possui em virtude de pessoas com capacidades inferiores ao requerido para o correcto desempenho da função, por muito motivadas que estejam, não conseguem alcançar níveis de desempenho elevados. Outra variável a considerar na relação entre as dimensões do trabalho e os resultados finais será a satisfação com o contexto, isto porque uma pessoa que se sinta fortemente insatisfeita com o salário ou com a chefia, é menos provável que responda de forma positiva às características da função.

Este modelo irá avaliar a motivação com o conteúdo do trabalho através do Potencial Motivador do Trabalho - PMT (Vala, Monteiro, Lima \& Caetano, 1995). O PMT é determinado 
através da combinação dos scores obtidos nas cinco características centrais do trabalho (Ferreira et al., 2001). O cálculo deste índice efectua-se com base na seguinte fórmula:

PMT $=\frac{(\text { variedade }+ \text { identidade }+ \text { significado })}{3} \times$ autonomia $\times$ feedback

Desta forma, quanto mais elevado for o valor do PMT, mais elevada será a motivação, a satisfação e o desempenho do indivíduo.

\section{Síntese}

O interesse em estudar a motivação no trabalho, do lado dos colaboradores, é considerado por uma visão humanitária que indica que as pessoas merecem ser tratadas de forma justa e com respeito (Kopelman, Brief, \& Guzzo, 1990). Do lado da gestão, a motivação no trabalho tem vindo a ser considerada como um facto que induz a comportamentos (por parte dos colaboradores) promovedores do desempenho individual e organizacional, traduzindo-se esta numa relação circular.

A literatura acerca da motivação no trabalho divide os factores determinantes da motivação no trabalho em três grupos distintos: (1) Características da Organização; (2) Aspectos específicos da função e dos Sistemas de Incentivos associados; (3) Características indivíduais (Locke, 1976; Hackman \& Oldham, 1980).

Hackman e Oldham (1980) desenvolveram a Teoria das Características da Função, essencial para este trabalho, já que esta teoria preconiza que as pessoas podem ser motivadas pela satisfação intrínseca que sentem ao executar as funções. Quando consideram o seu trabalho com significado, que assumem a responsabilidade sobre este e quando conhecem os resultados do trabalho efectuado, estas irão gostar mais do seu trabalho e sentir-se-ão motivadas a desempenhálo melhor. De acordo com esta teoria, há cinco características fundamentais que podem ser aplicadas a qualquer função: variedade de competências, identidade com a tarefa, significado da tarefa, autonomia e feedback.

Assim, e de acordo com a literatura existente, os indivíduos altamente motivados tendem a sentir-se mais envolvidos no trabalho, o que induz a um aumento de esforço e dedicação na execução das tarefas, promovendo consequentemente o bom desempenho no seu trabalho. 


\section{Desempenho}

\section{Abordagem geral}

Através dos trabalhos elaborados por vários autores (e.g. Schmidt et al., 1992; Hunter \& Schmidt, 1996; Welbourne et al., 1998) podemos dizer que o desempenho dos colaboradores nas empresas tem sido alvo de inúmeros estudos no âmbito do Comportamento Organizacional e Gestão de Recursos Humanos.

Como resultado da maior competição no mercado, muitas empresas sentem que os seus colaboradores podem constituir uma vantagem competitiva relativamente às outras empresas no mercado e consequentemente podem contribuir para o desempenho da organização. Assim, os colaboradores irão ter um papel decisivo no sucesso organizacional sendo por isto tão importante estudar este fenómeno no contexto organizacional.

A palavra Desempenho é utilizada nos mais diversos campos da gestão mas apesar do uso frequente desta palavra o seu significado aparece muitas vezes associado a outros conceitos distintos como o de produtividade e eficácia.

Cunha et al. (2004) foram alguns autores que fizeram a distinção entre estes 3 conceitos tendo definido a produtividade como (...) mais do que a soma dos resultados individuais, estando relacionada, por exemplo, com o grau de coordenação no uso dos recursos humanos ou com a disponibilidade dos recursos materiais e imateriais para o processo produtivo". Segundo estes autores, a eficácia pode ser definida como a "relação entre os outputs e algum padrão ou expectativa. Refere-se à medida de obtenção ou não dos objectivos e normalmente remete-nos para a organização”. A principal diferença entre o conceito de desempenho individual e os dois conceitos definidos anteriormente será o facto de que quando falamos em desempenho individual tendemos a centrar-nos numa perspectiva individual e os termos produtividade e eficácia remetem-nos para o nível organizacional (Pritchard, 1992). Assim, o desempenho pode ser definido como a "medida dos resultados individuais ou uma comparação entre as expectativas de desempenho e o desempenho real (Cunha et al., 2004) ou como o "grau em que a pessoa ajuda a organização a alcançar os seus objectivos” (Motowidlo \& Borman, 1997).

Estes conceitos estão intimamente ligados porque tal como demonstram os estudos de alguns autores, a produtividade global de uma organização depende significativamente do desempenho dos seus colaboradores (Hunter, Schmidt e Judiesch, 1990). 
Campbell (1990, cit por Cunha et al, 2004) caracterizou o desempenho como as acções ou comportamentos relevantes para o cumprimento dos objectivos organizacionais. O modelo introduzido por este autor foi um dos primeiros a ser desenvolvido neste âmbito, no entanto reflecte, uma ideia consensual que se mantém até aos dias de hoje, que é a do desempenho ser um conceito multidimensional. Apesar disto, existem autores que defendem que se deve restringir a um critério enquanto outros defendem que devem ser avaliados vários, podendo factores externos como a diminuição da atenção com o tempo, e factores intrapessoais de quem avalia (experiência, capacidade, etc.), interferir na qualidade das medições (Borman, 1992). Para além do exposto anteriormente interessa focar que o desempenho é um conceito dinâmico e complexo uma vez que mede para além de resultados, comportamentos humanos.

Pritchard (1992) defende que o desempenho individual é uma medida do quão bem o indivíduo cumpre o seu papel sendo comum avaliar esta dimensão estudando a forma como o indivíduo se comporta em relação às expectativas organizacionais.

Motowidlo e Borman (1997), defendem que o desempenho individual pode ser concebido como o grau em que o indivíduo contribui para que a organização atinja os objectivos e os autores. Estes autores dividem o desempenho em duas componentes:

1. Comportamentos: dizem respeito aos comportamentos que são avaliados quer positiva quer negativamente tendo em conta a eficácia organizacional;

2. Resultados: diz respeito à alteração das condições das pessoas ou coisas resultantes do desempenho e que podem trazer efeitos positivos ou negativos para o cumprimento dos objectivos da organização.

Segundo Murphy, Cleveland, Skatebo e Kinney (2004), o desempenho individual relaciona-se com o que as pessoas fazem na realidade e que pode ser observável e refere-se a acções que ocorrem no âmbito de uma função e que respondem a determinados padrões.

Mais à frente neste trabalho iremos desenvolver a temática sobre Avaliação de Desempenho, sendo esta uma das variáveis em estudo, e que na Instituição em causa integra a avaliação de dois tipos de Desempenho: Desempenho de tarefa e Desempenho Contextual/Extra-tarefa.

O Desempenho de tarefa caracteriza-se pela "eficácia com que os incumbentes dos cargos levam a cabo actividades que contribuem para o núcleo técnico, seja directamente através da implementação de uma parte do seu processo tecnológico, seja, indirectamente, proporcionando-lhe os materiais ou serviços necessários" (Borman e Motowidlo, 1997). O desempenho de tarefa refere-se às funções específicas inerentes ao descritivo de funções e 
engloba as actividades que suportam o núcleo técnico de uma organização, ou o sistema de transformação de inputs em outputs das organizações.

O Desempenho Contextual ou Extra-tarefa difere do Desempenho de tarefa porque enquanto o último utiliza o conhecimento sobre factos e príncipios relacionados com o núcleo técnico de uma organização, o desempenho contextual utiliza conhecimentos de factos, princípios e procedimentos relacionados com situações de ajuda e cooperação com outros. Este tipo de desempenho não consta no descritivo de funções mas é, contudo, considerado um importante componente do desempenho organizacional.

Avaliação de Desempenho

A prática da avaliação, no seu sentido genérico, é inerente à natureza humana assim como é também a base para tomada de decisão que está presente em toda a escolha. As organizações, procuram atrair e seleccionar colaboradores que apresentam os mesmos valores e crenças e utilizam sistemas de reconhecimento, para estimular e tentar garantir os desempenhos considerados adequados e desejáveis às suas realidades. Contudo, poderá haver um gap entre o desempenho real e o desempenho esperado.

A Avaliação de Desempenho foi originalmente estruturada para mensurar o desempenho e o potencial do colaborador, tratando-se de uma avaliação sistemática, feita pelas chefias familiarizadas com a natureza das funções dos seus colaboradores.

Segundo Scott (1998), a Avaliação de Desempenho é a apreciação sistemática de um subordinado segundo um trabalho realizado, as suas competências e outras qualidades necessárias para a boa execução das suas tarefas; Esta avaliação está ligada, frequentemente mas não necessariamente, a vantagens financeiras com o objectivo de motivar os colaboradores.

Existem diversos métodos para avaliar o desempenho dos colaboradores sendo que nos iremos focar mais nos métodos que se aproximam à realidade da empresa deste estudo.

Chiavenato (1981) propõe a avaliação de desempenho por objectivos. Esta é hoje em dia, a forma de avaliação de desempenho mais utilizada na maioria das organizações, pois é aquela que permite um maior envolvimento das pessoas na gestão estratégica e, consequentemente, na vida das organizações. De facto, a avaliação de desempenho por objectivos parte de um processo de definição de objectivos em cascata, que exige a participação de todos os membros para ser implementado. De acordo com o autor, neste método, a chefia e o colaborador negoceiam os 
objectivos a alcançar durante um período de tempo. Os objectivos devem ser específicos, mensuráveis e devem estar alinhados aos objectivos da organização. Periodicamente a chefia e o colaborador devem reunir-se e discutir o nível de desempenho, podendo ser renegociados os objectivos. O colaborador precisa de estar motivado para apresentar planos, propor correcções e sugerir novas ideias. Em contrapartida, a chefia deve comunicar o seu agrado (ou desagrado) perante os resultados alcançados e propor também acções a implementar, necessárias para melhorar o desempenho profissional e pessoal de cada um dos colaboradores da empresa. A avaliação vai assim ganhando forma através da análise do desempenho do colaborador. Neste método, a avaliação do desempenho está limitada aos objectivos definidos inicialmente. A chefia nunca deverá ter em conta aspectos que não estavam previstos nos objectivos, ou que não tivessem sido comunicados ao colaborador.

Devido à constante e crescente competitividade entre as empresas e às contínuas mudanças de padrões de comportamento pessoal, profissional, cultural e organizacional presentes nas mesmas é necessário que exista uma reformulação nos modelos e práticas de monitorização do desempenho. Segundo Vroom (1997), esta nova abordagem implica mudar a ênfase da avaliação passiva para a análise ou avaliação activa do desempenho, passando os colaboradores a fazer uma auto-avaliação, identificando não apenas os seus pontos fracos, mas também os seus pontos fortes e o seu potencial de crescimento. Passam a ser agentes activos da avaliação do seu desempenho.

Gramignia (2002) refere que é possível pensar na avaliação de desempenho por competências como um poderoso meio de identificar o potencial de cada colaborador, melhorar o desempenho da equipa e a qualidade das relações dos colaboradores com os seus superiores, assim como motivar os colaboradores a assumir a responsabilidade pela excelência dos resultados pessoais e organizacionais.

A avaliação por competências é um sistema organizacional que tem como objectivo melhorar as competências profissionais dos colaboradores, as habilidades e conhecimentos determinantes para a sua eficácia profissional e também as lacunas de qualificação do colaborador para tarefas específicas e fornece recursos para melhorar as suas capacidades.

Em suma, o sistema de avaliação de desempenho constitui um dos instrumentos de gestão mais eficazes no sentido de promover a partilha de objectivos de gestão e simultaneamente fomentar o papel do gestor como orientador dos seus colaboradores, para que se estabeleça na empresa uma "cadeia" de compromisso na satisfação dos objectivos de negócio definidos, na medida da responsabilidade e desempenho de cada colaborador. É um processo conjunto entre a chefia e os seus colaboradores directos para identificação dos meios e condições 
necessárias à implementação de acções concretas, tendo em vista os princípios base da Instituição (Avaliação Qualitativa) e os objectivos individuais definidos (Avaliação Quantitativa).

O processo de Avaliação de Desempenho deve ainda traduzir-se no acompanhamento e aconselhamento contínuo dos colaboradores. Cowling e Mailer (2003) referiram que todos os colaboradores devem dar uma contribuição para os objectivos da organização que os emprega. Esta contribuição deve ser regular e sistematicamente avaliada. Apenas assim será possível suportar uma análise realista e crítica relativamente a desempenhos observados no decorrer de um determinado período, bem como capacidades e conhecimentos, necessidades e interesses demonstrados. Este acompanhamento contínuo permitirá fomentar o desenvolvimento dos colaboradores e a sua contribuição para os resultados da mesma.

Os colaboradores devem conhecer o que a empresa espera deles, compreender o motivo pelo qual lhes são estabelecidos comportamentos padrão e objectivos e conhecer os meios e condições necessários tendo em vista o alcançar dos standards definidos. Desta forma, deverão ser confrontados com os resultados do seu desempenho de forma a poderem desenvolver as mudanças consideradas mais convenientes.

\section{Síntese}

O desempenho tem sido alvo de inúmeros estudos na área do Comportamento Organizacional e Gestão de Recursos Humanos.

O desempenho é um conceito complexo devido ao facto da organização ser julgada e avaliada pelo seu desempenho que é directamente influenciado pelo desempenho dos seus colaboradores.

Apesar dos diferentes tipos de desempenho abordados na literatura, neste trabalho abordámos apenas 2 tipos de desempenho: contextual e de tarefa, em virtude de serem estes que são contemplados no sistema de avaliação da empresa presentemente estudada.

A mensuração do desempenho tem sido objecto da psicologia aplicada há mais de 60 anos pela sua importância nas decisões organizacionais relacionadas com gestão de recursos humanos ou outros, no entanto, existe uma grande dificuldade em medir este conceito correctamente e por isso é, até à actualidade, um dos maiores problemas dos investigadores (Landy \& Farr, 1983). 
Existindo a necessidade de medir desempenho a definição de critérios é essencial (Borman, 1992). A mensuração do desempenho conta com várias abordagens conceptuais e operacionais devendo as medidas obedecer a princípios de fidelidade, validade e especificidade, serem práticas e úteis, fornecer informação clara, serem providas de significado para quem avalia e é avaliado e estarem relacionadas com os objectivos organizacionais (Landy \& Farr, 1983).

Assim, a implementação do Modelo de Avaliação de Desempenho permitirá alinhar os Recursos Humanos com os objectivos estratégicos da empresa, promover o compromisso organizacional através de uma cultura de mobilidade, de pertença e de compromisso para a empresa e potenciar uma mudança organizacional através do compromisso dos colaboradores com os objectivos e valores da empresa. Neste contexto, a Avaliação de Desempenho ajudará a implementar e reforçar a estratégia da empresa maximizando os resultados do negócio, criando valor através das pessoas. 
Objectivos e Hipóteses de Investigação

Após a revisão da literatura existente sobre IE, denota-se um esforço considerável para desenvolver este constructo que está ainda mal definido. São imensas as tentativas de definição e operacionalização, que se agregaram, essencialmente, em dois modelos teóricos que operacionalizam este constructo de diferentes formas.

Apesar de haver algumas teorias e literatura sobre a temática da IE, os estudos efectuados são escassos, não havendo ainda muita base de estudo neste sentido. Os estudos efectuados têm tido por base a relação da IE com o desempenho em vendas. Dawn e Sojka (2003) e Rozell, Pettijohn e Parker (2006) abordaram este tema mas estudaram apenas a relação entre IE e vendedores com elevado desempenho. Em ambos os estudos, relacionou-se o nível de IE e o desempenho dos vendedores e confirmou-se que os vendedores que tinham um maior desempenho eram, também, os que apresentavam maior nível de IE.

Cunha et al. (2004) sugeriram que de acordo com alguns estudos efectuados é possível retirar algumas conclusões sobre a relação entre IE e Desempenho tais como: (1) as aprendizagens de sucesso e os mais elevados desempenhos surgem da reunião sinérgica das capacidades racionais e emocionais; (2) a combinação do QI e da IE explica uma maior variação no desempenho do que apenas o QI; (3) para que a IE exerça efeitos positivos sobre o desempenho dos indivíduos, é necessário que estes disponham de um patamar mínimo de QI; (4) Por conseguinte, o QI parece necessário, mas não suficiente, carecendo os seus efeitos positivos da presença do QI para que possa suscitar mais elevados desempenhos. Goleman (1995) sugere que as pessoas mais bem sucedidas, em termos pessoais e profissionais, nem sempre eram intelectualmente brilhantes, mas todas elas eram dotadas de um nível elevado de IE.

Dada a escassez de estudos que relacionam IE e Desempenho, não foi possível encontrar nenhum estudo que relacionasse a IE com a Avaliação de Desempenho dos colaboradores, mas podemos encontrar nos estudos de Goleman (1995) algumas pistas para podermos considerar a relação entre estas duas variáveis como positiva, visto este autor afirmar que as pessoas que atingem um maior sucesso quer na vida profissional, quer na vida pessoal, são as que apresentam um nível elevado de IE.

Assim, torna-se pertinente e importante estudar se a IE influencia a Avaliação de Desempenho dos colaboradores. 
Hipótese 1: A IE tem um efeito directo na Avaliação de Desempenho dos Colaboradores

Será importante compreender qual a relação entre IE e Motivação e entre a motivação e a Avaliação de Desempenho para sustentação da nossa segunda hipótese em estudo.

As palavras motivo e emoção derivam ambas da mesma raiz latina, motere, "mover". As emoções são, literalmente, o que nos move na busca dos nossos objectivos; alimentam as nossas motivações e os nossos, por seu turno, dirigem as nossas percepções e modelam os nossos actos. Um grande trabalho começa com grandes sentimentos (Goleman, 1995). O mesmo autor abordou quatro componentes de inteligência emocional, sendo uma delas a motivação. Um índivíduo que lida de forma emocional com os outros, com entusiasmo e persistência, actua para além das expectativas e inspira os outros a fazerem o mesmo. Assim, será de esperar que um indivíduo com elevada IE terá uma maior capacidade de auto-motivar no desempenho da sua função (Goleman, 2003).

Alguns autores como Peiró, Pietro e Spector (cit por Ferreira et al., 2001) afirmam que a motivação é influenciada por variáveis situacionais e individuais sendo as últimas, características disposicionais dos indivíduos nas quais se insere também a IE. Estas variáveis irão contribuir para o aumento ou a diminuição da motivação no local de trabalho. Devido à escassez de estudos que relacionem a IE com a Motivação este estudo será importante para aprofundar a relação entre estas duas varíaveis em contexto organizacional.

A motivação no trabalho foi também um conceito que começou a reunir o interesse dos teóricos, investigadores e gestores desde a altura em que o modelo taylorista da organização do trabalho foi posto em causa e se valorizou o factor humano na empresa. Desde então que esta variável tem sido considerada muito importante por estar também ela associada ao desempenho (Cunha et al., 2004).

Devido à evidência empírica reunida, a tendência foi de se avaliar, não um índice global de motivação para com o trabalho mas as diferentes dimensões que a integram, tais como as características organizacionais, as características da função e as características pessoais.

Os testes do modelo de Hackham e Oldham mostram que a presença das características da função referidas anteriormente, tendem a aumentar a motivação instrínseca dos colaboradores, bem como a satisfação geral face ao trabalho e por consequencia o alcançar de melhores resultados no desempenho dos colaboradores (e.g., Dodd \& Ganster, 1996 cit por Cunha et al, 2004).

Também segundo Cunha et al. (2004), “a motivação é uma variável mais indicada (...) para influenciar o desempenho e os resultados produtivos". 
Não foi possível encontrar estudos de mediação da Motivação entre a IE e a Avaliação de Desempenho, mas considerando a literatura apresentada e a relação entre as variáveis de IE e Motivação com o Desempenho, será expectável que a relação de IE com a Avaliação de Desempenho seja influenciada por uma variável mediadora, a Motivação.

Hipótese 2: A IE é mediada pela motivação na sua relação com a Avaliação de Desempenho dos Colaboradores. 


\section{MÉTODO}

Neste capítulo é dado a conhecer as características da organização onde foi recolhida a amostra, os participantes que contribuíram para a realização deste estudo, o design utilizado na investigação, os instrumentos utilizados e o procedimento.

\section{Caracterização da organização}

O presente estudo foi realizado numa empresa multinacional no sector financeiro que está implementada em Portugal desde o ano 1981 e que em 2004 iniciou um forte projecto expansão em Portugal. Trata-se de um grupo financeiro com mais de 300 anos que está presente nos 5 Continentes e em mais de 60 países e conta com cerca de 100 mil clientes.

A missão desta empresa é ser a melhor empresa no sector em que serve e a melhor empresa para trabalhar em Portugal.

$\mathrm{Na}$ altura da recolha de dados (Agosto 2009) a empresa conta com mais de 200 agências em todo o país e mais de 2000 colaboradores, sendo portanto uma organização em forte expansão em Portugal.

\section{Participantes}

Por já terem sido efectuados vários estudos na área de vendas (e.g. Mauthner, 2004 \& Afonso, 2008), esta amostra foi dividida em dois grupos distintos: os colaboradores que exercem as suas funções nos serviços centrais sem contacto directo com os clientes e os colaboradores que estão no front-office, estando em contacto permanente e directo com os clientes.

Participaram no estudo 892 colaboradores, num total de 247 colaboradores do BackOffice e 645 do Front-office. 
O método de amostragem utilizado foi não probabilístico, ou, mais especificamente, foi o método por conveniência pois a amostra foi constituída apenas pelos colaboradores com vínculo à empresa de efectividade e contrato a termo e a quem foi atribuída uma nota de Avaliação de Desempenho no ano de 2008. O método de amostragem por conveniência baseia-se na premissa de que se selecciona a amostra em função da disponibilidade e acessibilidade dos elementos que constituem a população alvo (Hill \& Hill, 2002).

Considerando a distribuíção por género dos participantes, do total de 892 colaboradores que responderam aos questionários, 409 são do sexo feminino (46\%) e 483 do sexo masculino (54\%) (Figura 3).

Figura 3: Distribuição dos participantes segundo o género

\section{Género}

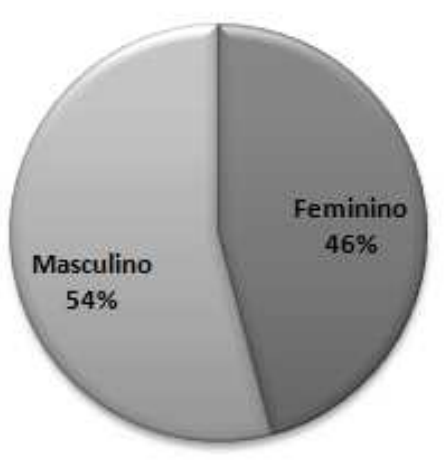

Foi também possível recolher informação dos colaboradores acerca da sua idade, anos de experiência profissional, antiguidade na empresa, habilitações literárias e tipo de função.

Relativamente à Idade, os indivíduos indicaram a sua idade exacta, tendo posteriormente sido criadas seis classes etárias (Figura 4).

As categorias de habilitações literárias foram criadas tentando abarcar as mais comuns (Até ao $9^{\circ}$ ano, $9^{\circ}$ até $12^{\circ}$ ano, Bacharelato, Licenciatura e Outra). As outras situações abragem a frequência universitária e os cursos profissionais (Figura 5).

Apresentam-se em seguida os gráficos que caracterizam a amostra relativamente às variáveis demográficas. 
Figura 4: Distribuição dos participantes de acordo com as classes etárias

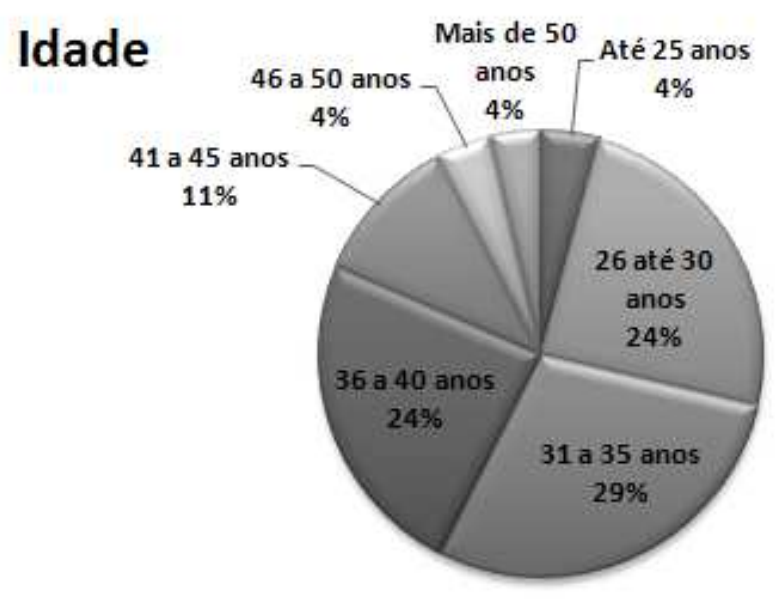

Como se pode verificar no gráfico anterior, mais de 57\% dos participantes encontram-se abaixo da faixa etária dos 35 anos, demonstrando que a população desta empresa é bastante nova comparativamente à realidade existente noutros grupos financeiros do nosso país.

Figura 5: Distribuição dos participantes de acordo com o nível de escolaridade

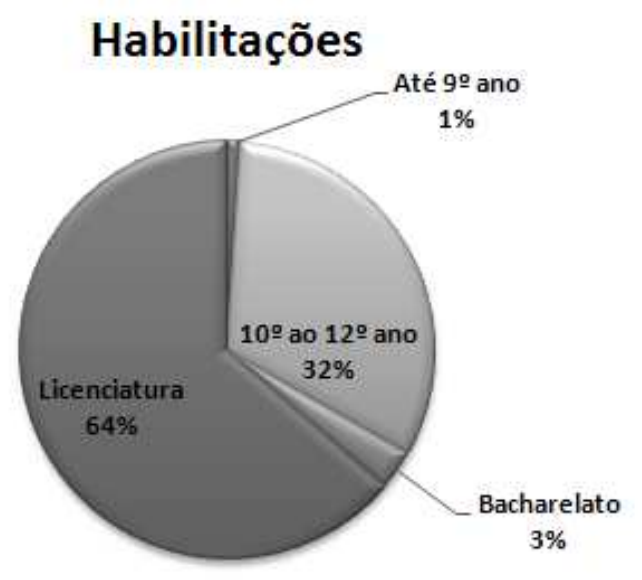

Como se pode verificar a maioria dos indivíduos têm a Licenciatura como habilitações literárias.

Nas categorias de Antiguidade (Figura 6) na empresa e Anos de experiência profissional (Figura 7) foram criadas seis faixas temporais. 
Figura 6: Distribuição dos participantes de acordo com a antiguidade na empresa

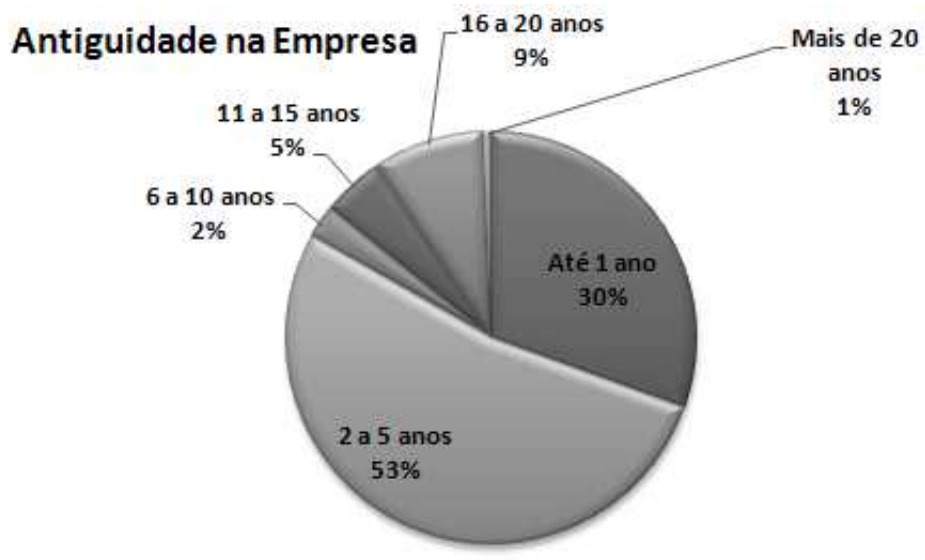

Pode-se verificar através da análise do gráfico anterior que a empresa em estudo conta com colaboradores recentes, tendo a grande maioria de 2 a 5 anos de casa. É ainda de salientar que um número bastante significativo tem até 1 ano de antiguidade na empresa em estudo o que demonstra a entrada constante de pessoas na empresa devido como já referido anteriormente ao projecto de expansão pela qual a mesma atravessa.

Figura 7: Distribuição dos participantes de acordo com o número de anos de experiência profissional que possuem.

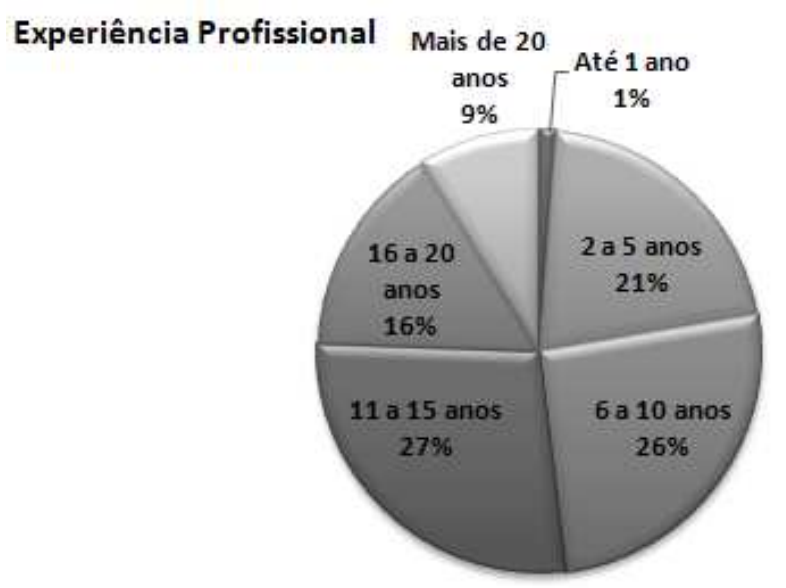

Pode-se verificar pelo gráfico anterior que a experiência profissional anterior dos funcionários da empresa em estudo é bastante distribuída pelas várias faixas do gráfico. É de salientar que apesar dos colaboradores não estarem há muito tempo na empresa, mais de $70 \%$ deles já trazem consigo bastante experiência e consequente conhecimento técnico adquirido de outras experiências profissionais anteriores. 
Figura 8: Distribuição dos participantes de acordo com o tipo de função.

\section{Tipo de Função}

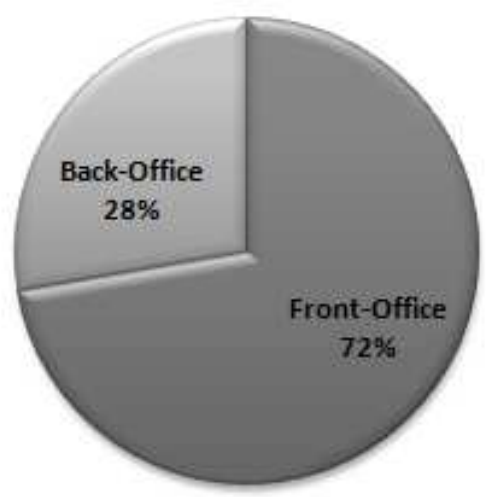

Dado o projecto de expansão da empresa em que se apostou fortemente no crescimento orgânico pode verificar-se pelo gráfico anterior que a maioria dos colaboradores da empresa têm funções de front-office.

\section{Instrumento}

No que diz respeito à operacionalização das variáveis em estudo, a mesma processa-se com base em dois instrumentos: Uma escala de IE, desenvolvida por Rego, A. \& Fernandes (2005); Uma escala de Motivação, tradução do JDS (Job Diagnostic Survey) (Almeida, Faísca, Jesus, 2007).

\section{Inteligência Emocional}

De modo a medir a IE, foi utilizada a escala desenvolvida por Rego, A. \& Fernandes (2005), devidamente validada para a população portuguesa, a qual permite avaliar 6 dimensões (Anexo A e B):

1. Compreensão das emoções próprias;

2. Auto-Controlo perante as críticas;

3. Auto-encorajamento (uso das emoções);

4. Auto-controlo emocional (regulação das emoções);

5. Empatia;

6. Compreensão das emoções dos outros; 
O questionário é constituído por 23 itens, numa escala de Likert que varia do 1 (não se aplica rigorosamente nada a mim) ao 6 (aplica-se completamente a mim). Trata-se de uma medida de auto-relato. A escala de Likert original no estudo de Rego et al. (2005) seria uma escala de 7 pontos que foi adaptada neste estudo para uma escala de 6 pontos devido a que escalas ímpares induzem normalmente os sujeitos a darem respostas centrais na escala.

Os alphas de Cronbach encontrados por Rego e Fernandes (2005), tendem a superar o patamar de 0,80 sugerido por Bryman \& Cramer (2003). Mais especificamente, os valores dos Alphas de Cronbach das dimensões "Compreensão das emoções próprias", "Auto-Controlo perante as críticas", "Auto-Encorajamento", "Auto-Controlo Emocional", "Empatia" e "Compreensão das emoções dos outros" são, com esta sequência os seguintes: 0.82, 0.79, 0.77, 0.70, 0.79 e 0.67 . Na Tabela 5 podemos observar as médias, desvios-padrão e correlações encontradas pelos autores para as seis sub-dimensões da escala de IE referentes às 2 amostras estudadas pelos autores.

Tabela 5: Médias, desvio-padrão e correlações entre variáveis para as duas amostras (\#)

\begin{tabular}{|c|c|c|c|c|c|c|c|c|c|}
\hline & Média & DP & 1 & 2 & 3 & 4 & 5 & 6 & 7 \\
\hline \multirow{2}{*}{$\begin{array}{l}\text { Compreensão } \\
\text { das emoções } \\
\text { próprias }\end{array}$} & 5,1 & 0,9 & - & & & & & & \\
\hline & 5,0 & 0,9 & & & & & & & \\
\hline 2. Autocontrolo & 5,2 & 0,8 & $0,23^{*} *$ & - & & & & & \\
\hline $\begin{array}{l}\text { perante as } \\
\text { críticas }\end{array}$ & 5,0 & 1,0 & $0,11^{*}$ & & & & & & \\
\hline 3. Auto- & 5,5 & 0,9 & $0,36 * * *$ & $0,31^{*} k_{k} *$ & - & & & & \\
\hline encorajamento & 5,4 & 0,9 & $0,44^{*} * *$ & 0,21 *k* & & & & & \\
\hline 4. Autocontrolo & 4,0 & 1,1 & 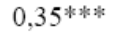 & $0,16^{*}$ & 0,14 & - & & & \\
\hline emocional & 4,2 & 0,9 & $0,36^{*} * * *$ & $-0,05$ & $0,27^{*}$ *水水 & & & & \\
\hline \multirow[t]{2}{*}{ 5. Empatia } & 5,6 & 0,8 & $0,35^{*}$ 水水 & 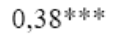 & $0,33^{\text {*2* }}$ * & $0,17^{*}$ & - & & \\
\hline & 5,3 & 0,9 & $0,16^{* *}$ & $0,25^{*} * *$ & $0,33^{*} k^{2} *$ & 0,05 & & & \\
\hline \multirow[t]{2}{*}{ 6. Compreensão } & 5,4 & 0,7 & $0,38 * * *$ & 0,39 *** & 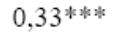 & 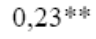 & $0,40^{*}$ 水水 & - & \\
\hline & 5,2 & 0,7 & 0,29 k $k_{*} *$ & $0,24^{*}$ *水 & $0,42^{* * *}$ & $0,14^{*}$ & $0,64^{*}$ *水 & & \\
\hline
\end{tabular}

Acresce ainda que os índices de ajustamento do modelo de seis factores sugerido por Rego e Fernandes (2005), são bastante satisfatórios. Mais especificamente: o rácio quiquadrado/graus de liberdade (DMIN/DF) apresenta um valor de 1.9, o CFI de 0.84 e um RMSEA de 0.08 .

Sendo a IE uma variável métrica é apropriado utilizar a média e o desvio-padrão como medidas de tendência central e dispersão respectivamente. Apresentamos também valores mínimo e máximo para esta variável. Assim, podemos observar para um $\mathrm{N}=880$, uma média de 
109.93, considerando como valores mínimo de 53 e máximo de 137 pontos. O desvio-padrão, sendo a medida que reflecte a dispersão dos resultados (Bryman \& Cramer, 2003), nesta amostra apresenta um valor de 10,73 .

Tabela 6: Análise Descritiva IE

\begin{tabular}{|c|c|c|}
\hline \multicolumn{3}{|c|}{ ESTATÍSTICA } \\
\hline \multirow[t]{2}{*}{$\mathbf{N}$} & Válidos & 880 \\
\hline & Valores em branco & 0 \\
\hline \multicolumn{2}{|c|}{ Media } & 109,93 \\
\hline \multicolumn{2}{|c|}{ Desvio-Padrão } & 10,73 \\
\hline \multicolumn{2}{|c|}{ Minímo } & 53,00 \\
\hline \multicolumn{2}{|c|}{ Máximo } & 137,00 \\
\hline
\end{tabular}

Procedemos à estatística descritiva das sub-dimensões da IE que apresentamos no Anexo C.

\section{Motivação}

Foi utilizada a escala traduzida do JDS (Job Diagnostic Survey) (Almeida et al., 2007) (Anexo A). Esta escala é composta por 15 itens pertencentes a cinco dimensões (Anexo B):

1. Autonomia do Trabalho;

2. Identidade do Trabalho;

3. Variedade do Trabalho;

4. Significado do Trabalho;

5. Feedback do trabalho.

Na primeira parte do questionário foi utilizada uma escala de Likert de 7 pontos em que a cotação é adequada a cada questão. Na segunda parte do questionário, foi utilizada uma escala de Likert de 7 pontos que varia do 1 (Muito Imprecisa) ao 7 (Muito Precisa). Trata-se de uma medida de auto-relato.

Em virtude da tradução desta escala estar ainda in Press aguardando a aprovação dos revisores, não será possível apresentar valores das suas qualidades métricas. Apenas obtivémos informação de que os valores das correlações encontrados entre as sub-dimensões da motivação foram semelhantes aos dos estudos iniciais de Hackman e Oldham (1976) em que os cinco factores apresentavam valores correlacionais médios moderados de 0,24 , que oscilavam entre 0,16 (valor mínimo) e 0,51 (valor máximo).

$\mathrm{Na}$ análise descritiva desta variável quantitativa na distribuição em estudo (Tabela 7), podemos observar com um $\mathrm{N}=880$, um valor médio de 3364, considerando como valores mínimo de 266.67 e máximo de 7497 pontos. O desvio-padrão, apresenta um valor de 1506. 
Tabela 7: Análise Descritiva da Motivação

\begin{tabular}{|c|c|c|}
\hline \multicolumn{3}{|c|}{ ESTATÍSTICA } \\
\hline \multirow[t]{2}{*}{$\mathbf{N}$} & Válidos & 880 \\
\hline & Valores em Branco & 0 \\
\hline \multicolumn{2}{|c|}{ Média } & 3364 \\
\hline \multicolumn{2}{|c|}{ Desvio-padrão } & 1506 \\
\hline \multicolumn{2}{|c|}{ Minimo } & 266,67 \\
\hline \multicolumn{2}{|c|}{ Máximo } & 7497 \\
\hline
\end{tabular}

No anexo $\mathrm{C}$ constam os valores da estatística descritiva para as sub-dimensões da motivação.

\section{Avaliação de Desempenho}

Para medir o desempenho foram utilizadas as notas de Avaliação de Desempenho, referentes ao ano de 2008, cedidas pela organização. Assim, esta é uma medida directa, não tendo havido uma medição do Desempenho dos Colaboradores na Instituição.

A nota final atribuída a cada colaborador é uma ponderação de duas notas correspondentes à avaliação quantitativa e qualitativa que varia entre 4 níveis (de A a D) e que podemos ver descritas na Tabela 8:

Tabela 8: Níveis da Escala de Avaliação de Desempenho

\begin{tabular}{|c|c|}
\hline \multicolumn{2}{|r|}{ ESCALA DE AVALIAÇÃO DE DESEMPENHO } \\
\hline A & $\begin{array}{l}\text { Ultrapassa significativamente os critérios de desempenho na } \\
\text { maioria das áreas }\end{array}$ \\
\hline B & $\begin{array}{l}\text { Desde o atingir consistentemente os critérios de desempenho até } \\
\text { níveis onde estes são ultrapassados em algumas áreas }\end{array}$ \\
\hline C & $\begin{array}{l}\text { Atingir as exigências mínimas de desempenho (reflecte um } \\
\text { desempenho efectivo na função), podendo subsistir áreas onde uma } \\
\text { melhoria significativa é necessária }\end{array}$ \\
\hline D & Não atinge os critérios de desempenho de uma forma consistente. \\
\hline
\end{tabular}

A cada um destes níveis foi atribuído um valor numérico $(A=4 ; B=3 ; C=2$ e $D=1)$ que corresponde à nota final de avaliação de cada um dos colaboradores.

Assim, na Tabela 9, apresentamos a análise descritiva desta variável, que para um $\mathrm{N}=880$, podemos observar como valor médio 2.93, considerando como valores mínimo de 1 e máximo de 4 pontos. O desvio-padrão, apresenta um valor de 0.678. 
Tabela 9: Análise Descritiva da Avaliação de Desempenho

\begin{tabular}{|c|c|c|}
\hline \multicolumn{3}{|c|}{ ESTATÍSTICA } \\
\hline \multirow[t]{2}{*}{$\mathbf{N}$} & Válidos & 880 \\
\hline & Valores em Branco & 0 \\
\hline \multicolumn{2}{|c|}{ Média } & 2.93 \\
\hline \multicolumn{2}{|c|}{ Desvio-padrão } & 0.678 \\
\hline \multicolumn{2}{|c|}{ Minimo } & 1 \\
\hline \multicolumn{2}{|c|}{ Máximo } & 4 \\
\hline
\end{tabular}

\section{Design}

O presente estudo será um estudo correlacional, por pretender explorar as relações estatísticas existentes entre as variáveis IE, Motivação e Avaliação de Desempenho. Segundo Bryman e Cramer (2003), o plano correlacional é caracterizado pelo facto de o investigador não manipular qualquer variável e todas variáveis serem recolhidas no mesmo momento. Recorrendo à tipologia de Campbell e Stanley (1966 cit. por D’Oliveira, 2002), nos estudos correlacionais são pesquisadas relações entre as variáveis em estudo. A definição de qual a causa e qual o efeito, é algo que é feito pelo investigador. A possibilidade de existirem variáveis mediadoras e/ou moderadoras das relações em estudo é ilustrativa de um menor controlo de explicações alternativas para a causalidade, neste tipo de trabalho.

Este estudo será também um estudo de mediação, por tentar confirmar se existe uma relação mediadora da Motivação na relação da IE com a Avaliação de Desempenho.

Segundo Maroco (2007), em Psicologia e em Ciências Sociais e Humanas de uma forma geral, a relação entre uma variável independente e uma determinada variável dependente é com frequência mediada por uma terceira variável que transporta o efeito da variável independente sobre a variável dependente. 
Procedimento

O contacto com a empresa em estudo foi feito pessoalmente dado que o investigador trabalha na referida empresa. Os questionários foram enviados aos colaboradores dos quais tínhamos a nota da sua Avaliação de Desempenho referente ao ano de 2008, através de uma ferramenta informática que permite enviar os questionários on-line. Através deste sistema, as respostas dadas ficam registadas numa base de dados do programa, que posteriormente é exportada para o Excel. Paralelamente ao envio dos questionários, foi enviado pela direcção um e-mail explicativo do trabalho e o intuito da investigação a todos os colaboradores envolvidos no estudo.

Foram enviados questionários a 1081 colaboradores sendo que a aplicação dos questionários teve início na última semana de Julho de 2009.

Todos os funcionários foram informados da confidencialidade das respostas e do facto de serem individuais. Foi ainda transmitida a ideia que os itens eram de resposta rápida e instintiva. Em geral não existiram dúvidas em relação ao que foi pedido e devido tratar-se de um questionário com escalas de auto-relato não nos pareceu haver algum tipo de relutância em relação às respostas sobre as variáveis em estudo.

O final do período de recolha dos questionários foi Agosto de 2009. Sucedida a fase de recolha dos questionários, estes foram analisados tendo sido a taxa de retorno de resposta de $83 \%$.

O tratamento estatístico foi realizado com a versão 16.0 do programa SPSS (Statistical Package for the Social Sciences) e com a versão 17.0 do AMOS (Analysis of Moment Structures) (Arbuckle, 2006) inserido no programa de análise estatística SPSS. 


\section{RESULTADOS}

Este capítulo encontra-se dividido em duas partes. Na primeira serão apresentados os dados referentes às qualidades psicométricas das escalas. Seguidamente, e com o intuito de testar as hipóteses inicialmente formuladas, irão ser apresentados tratamentos estatísticos relevantes, que remetem para as relações entre as variáveis em estudo, Por fim, serão elaboradas análises suplementares que poderão complementar os resultados obtidos no teste de hipóteses.

\section{Estudo das Propriedades Psicométricas das Escalas}

Por motivos de adequabilidade ao estudo das variáveis foi necessário proceder a uma "limpeza" da base de dados, devido ao não preenchimento de alguns itens. Estes missing values foram substituídos pelo valor médio de cada item considerando o total de respostas para esse item. A redução da informação disponível através de um processo de depuração de observações e de indicadores pode trazer implicações ao estudo, ou seja, nos tratamentos principais são apenas usados os casos que não foram identificados como outliers pelos procedimentos estatísticos apropriados, e são apenas usados os itens com qualidades métricas superiores. O facto da dimensão da amostra ser grande, permite alguma folga na eliminação de casos restando de qualquer forma mais de oito centenas de observações.

Foram retirados $1.30 \%$ dos casos de um $\mathrm{N}=892$, o que equivale a 12 casos retirados da amostra total.

\section{Escala A - Inteligência Emocional}

\section{Sensibilidade}

A sensibilidade apresenta a capacidade que um teste tem em discriminar os sujeitos, segundo o factor que está a ser avaliado, isto é, capacidade para fornecer respostas diferentes consoante os sujeitos da aplicação, sendo considerada sensível quando se assemelha à distribuição teórica, considerada para a IE como normal. 
Uma distribuição nomal caracteriza-se por ser simétrica e mesocurtica; e por compreender 95\% das observações entre a média e dois desvios-padrão (Pestana \& Gajeiro, 2003)

Segundo Maroco (2007), existem vários testes estatísticos que podem ser utilizados para testar o ajustamento de distribuições amostrais a determinadas funções de distribuição teórica, sendo o teste de Kolmogorov-Smirnov (K-S) um dos testes utilizados com mais frequência. O mesmo autor referiu que os métodos paramétricos são robustos à violação do pressuposto da normalidade desde que as distribuições não sejam extremamento enviesadas ou achatadas e que as dimensões das amostras não sejam extremamento pequenas.

O teste de Kolmogorov-Smirnov deve utilizar-se com amostras de maior dimensão. No entanto, para amostras bastante grandes (dimensões à volta de 500 ou superiores), este teste é muito sensível e indica sistematicamente a rejeição da hipótese de normalidade da distribuição (Coelho, Cunha \& Martins, 2008, p. 75). Sempre que o teste de normalidade revela rejeição da hipótese nula, poder-se-á ainda analisar o ajustamento à distribuição normal nomeadamente através da assimetria e da curtose. Para a análise dos outputs a seguinte convenção é frequentemente utilizada: dividindo o valor do coeficiente de assimetria pelo erro padrão de assimetria e dividindo o valor do coeficiente de curtose pelo erro padrão de curtose, se ambos os resultados estiverem entre -2 e 2, o pressuposto de normalidade é considerado satisfeito (Coelho et al., 2008, p. 75).

Assim, analisaremos a normalidade dos dados não somente em função do K-S, mas também das medidas de assimetria e de curtose para a escala geral de IE.

De modo a simplificar a análise e torná-la mais perceptível procedemos à compilação dos resultados, da escala total de IE, segundo aplicação do K-S (Tabela 10) e dos parâmetros de normalidade (Tabela 11).

Tabela 10: Valores de Kolmogorov-Smirnov (K-S) para a escala de IE

\begin{tabular}{|c|c|c|c|}
\hline \multicolumn{4}{|c|}{ Teste de Normalidade (Kolmogorov-Smirnova) } \\
\hline & Statistic & df & Sig. \\
\hline IE & ,030 & 880 & 063 \\
\hline
\end{tabular}

O teste Kolmogorov-Smirnov (K-S) indica a normalidade da distribuição $(p=0.063>0.05)$. Analisando também os coeficientes de assimetria e de curtose confirma-se a tendência para a normalidade da distribuição, como se pode confirmar pela análise do quadro , 
onde se encontram os valores dos indicadores de normalidade, assimetria e curtose, para a totalidade da escala (23 itens).

Tabela 11: Parâmetros de Normalidade da IE

\begin{tabular}{lcccccc}
\hline $\begin{array}{c}\text { Assimetria } \\
\text { (A) }\end{array}$ & $\begin{array}{c}\text { Erro padrão } \\
\text { de assimetria } \\
\text { (B) }\end{array}$ & $\begin{array}{c}\text { A/B } \\
\text { IE }\end{array}$ & $\begin{array}{c}\text { Curtose } \\
\text { (C) }\end{array}$ & $\begin{array}{c}\text { Erro padrão } \\
\text { de Curtose } \\
\text { C. }\end{array}$ & C/D \\
\cline { 2 - 7 } & -0.059 & 0.082 & -0.72 & 0.360 & 0.165 & 2.18 \\
\hline a. Lilliefors Significance Correction
\end{tabular}

Também a representação gráfica (Figura 9) nos permite considerar que a escala é aproximadamente normal.

Figura 9: Distribuição da IE total

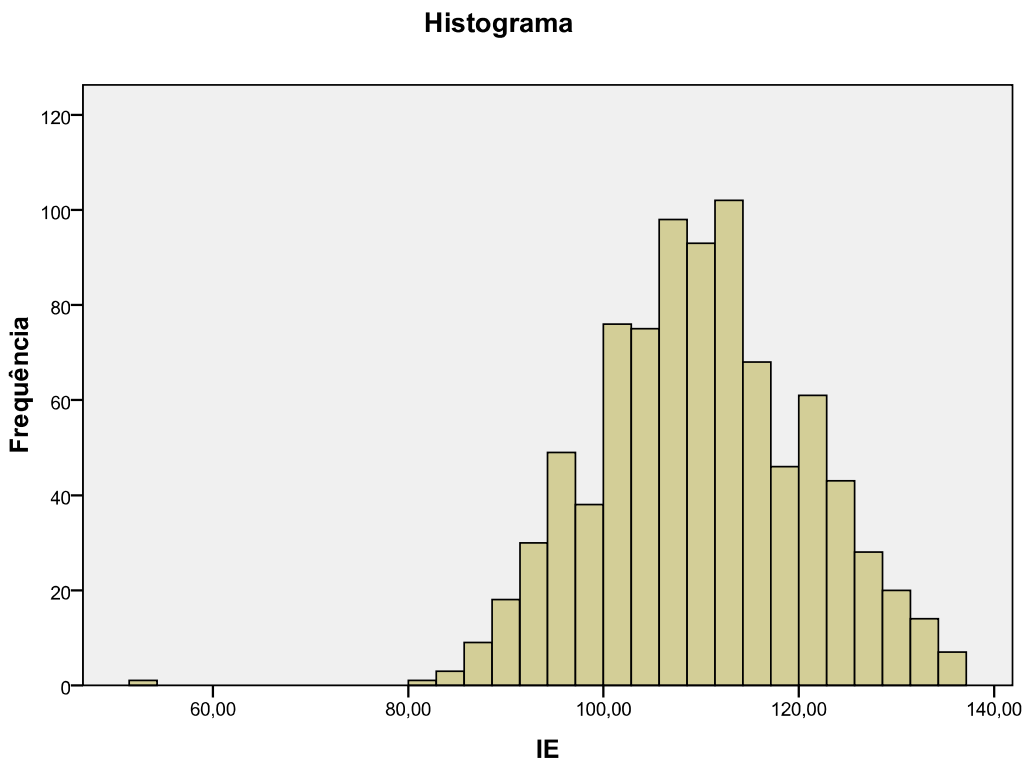

Em anexo são apresentados os valores relativos à análise da Sensibilidade para as seis subdimensões da IE (Anexo D).

\section{Fidelidade}

A Fidelidade de uma medida refere-se à sua consistência. Assim, a fidelidade é a qualidade métrica que garante a replicabilidade dos resultados, ou com seja, que garante, com determinado grau de confiança, a exactidão das medidas efectuadas. Por outras palavras, esperamos que a posição relativa do resultado de cada pessoa se mantenha relativamente constante em tempos de medição diferentes nas mesmas condições (Bryman \& Cramer, 2003). Existem diferentes formas 
de analisar a fidelidade, podendo ser esta avaliada ao nível da estabilidade temporal, da equivalência das formas e da consistência interna.

Neste trabalho, a fidelidade será avaliada através da consistência interna, que pode ser definida como a proporção da variabilidade das respostas e resulta de diferenças nos inquiridos. Esta propriedade pode ser medida através de diferentes métodos, sendo o Alpha de Cronbach o que foi utilizado neste trabalho e que pode ser definido como a correlação que se espera obter entre a escala utilizada e outras escalas hipotéticas do mesmo universo, com igual número de itens que meçam a mesma característica (Pestana \& Gagueiro, 2003).

O alpha de Cronbach é tradicionalmente utilizado em escalas tipo Likert sendo apontado como o indicador mais importante de fiabilidade de um instrumento (Ferreira, Tavares e Duarte, 2005). A determinação deste coeficiente tanto para o total da escala como para as dimensões, permite estimar a homogeneidade dos itens, isto é, até que ponto cada enunciado da escala mede o mesmo conceito de forma equivalente.

De modo a facilitar a interpretação, apresenta-se na Tabela 12 a relação entre o alpha de Cronbach e a qualidade da fidelidade da escala, segundo Hill e Hill (2002).

Tabela 12: Qualidade de Fidelidade de uma Escala:

\begin{tabular}{c|c}
\hline $\begin{array}{c}\text { Alpha de } \\
\text { Cronbach }\end{array}$ & Fidelidade \\
\hline$>0,9$ & Excelente \\
$0,8-0,9$ & Boa \\
$0,7-0,8$ & Razoável \\
$0,6-0,7$ & Fraca \\
$<0,6$ & Inaceitável \\
\hline Fonte: Hill e Hill $(2002)$ &
\end{tabular}

Para um N=880 e um total de 23 itens, calculou-se o alfa de Cronbach, obtendo-se um valor de $\alpha=.879$ para a totalidade do instrumento, o que indica segundo Hill e Hill (2002) uma boa fidelidade.

$\mathrm{Na}$ Tabela 13 podem observar-se os valores do alpha para cada item, se fosse retirável da análise. 

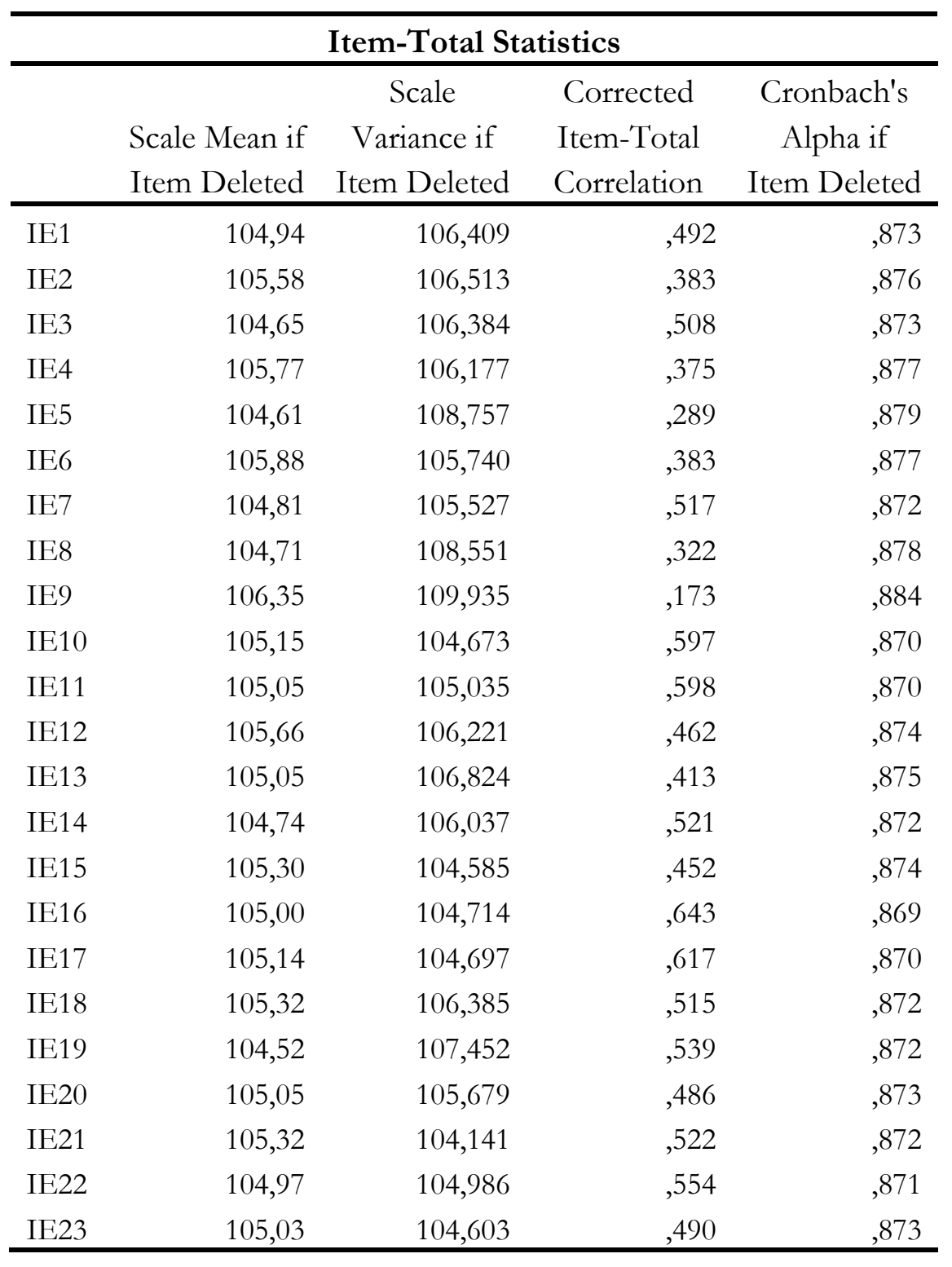
Sub-dimensões IE:

\begin{tabular}{|c|c|c|c|c|c|c|c|}
\hline & & $\begin{array}{l}\text { Compreensão } \\
\text { das próprias } \\
\text { emoções }\end{array}$ & $\begin{array}{c}\text { Auto } \\
\text { Controlo } \\
\text { perante as } \\
\text { criticas } \\
\end{array}$ & $\begin{array}{c}\text { Auto } \\
\text { Encorajamento }\end{array}$ & $\begin{array}{c}\text { Auto } \\
\text { Controlo } \\
\text { Emocional }\end{array}$ & Empatia & $\begin{array}{c}\text { Compreensão } \\
\text { das emoções } \\
\text { dos outros }\end{array}$ \\
\hline \multirow[t]{2}{*}{$\mathrm{N}$} & Válidos & 880 & 880 & 880 & 880 & 880 & 880 \\
\hline & Valores em Branco & 0 & 0 & 0 & 0 & 0 & 0 \\
\hline \multicolumn{2}{|c|}{ Média } & 24,5111 & 23,7204 & 15,5841 & 12,4984 & 19,3201 & 14,3030 \\
\hline \multicolumn{2}{|c|}{ Desvio-padrão } & 3,29533 & 3,40946 & 1,95961 & 2,39550 & 2,47182 & 1,93992 \\
\hline \multicolumn{2}{|c|}{ Mínimo } & 5,00 & 11,00 & 3,00 & 3,00 & 9,00 & 3,00 \\
\hline \multicolumn{2}{|c|}{ Máximo } & 30,00 & 30,00 & 18,00 & 18,00 & 24,00 & 18,00 \\
\hline
\end{tabular}

\section{Sub-dimensões Motivação:}

\begin{tabular}{|c|c|c|c|c|c|c|}
\hline & & Variedade & Identidade & Significado & Autonomia & Feedback \\
\hline \multirow[t]{2}{*}{$\mathrm{N}$} & Válidos & 880 & 880 & 880 & 880 & 880 \\
\hline & Valores em Branco & 0 & 0 & 0 & 0 & 0 \\
\hline \multicolumn{2}{|c|}{ Média } & 15,9622 & 13,7936 & 16,1746 & 13,9224 & 15,1109 \\
\hline \multicolumn{2}{|c|}{ Desvio-padrão } & 3,50648 & 3,24272 & 3,18502 & 3,49066 & 3,36825 \\
\hline \multicolumn{2}{|c|}{ Mínimo } & 3,00 & 3,00 & 4,00 & 3,00 & 3,00 \\
\hline \multicolumn{2}{|c|}{ Máximo } & 21,00 & 21,00 & 21,00 & 21,00 & 21,00 \\
\hline
\end{tabular}


Anexo D

Sensibilidade 


\section{Dimensões de IE}

Valores de Kolmogorov-Smirnov (K-S)

\begin{tabular}{|c|c|c|c|}
\hline \multicolumn{4}{|c|}{ Tests of Normality (Kolmogorov-Smirnova) } \\
\hline & Statistic & df & Sig. \\
\hline Compreensão das emoções & ,111 & 880 & 000 \\
\hline Auto Controlo perante as criticas & ,082 & 880 & 000 \\
\hline Auto Encorajamento & 131 & 880 & 000 \\
\hline Auto Controlo Emocional & 087 & 880 & 000 \\
\hline Empatia & ,096 & 880 & 000 \\
\hline Compreensão das emoções dos outros &, 126 & 880 & 000 \\
\hline
\end{tabular}

a. Lilliefors Significance Correction

Parâmetros de Normalidade das dimensões da IE

\begin{tabular}{|c|c|c|c|c|c|c|}
\hline & $\begin{array}{l}\text { Assimetria } \\
\text { (A) }\end{array}$ & $\begin{array}{l}\text { Erro padrão } \\
\text { de Assimetria } \\
\text { (B) }\end{array}$ & $\mathrm{A} / \mathrm{B}$ & $\begin{array}{l}\text { Curtose } \\
\text { (C) }\end{array}$ & $\begin{array}{l}\text { Erro padrão } \\
\text { de Curtose } \\
\text { (D) }\end{array}$ & $\mathrm{C} / \mathrm{D}$ \\
\hline $\begin{array}{l}\text { Compreensão das emoções } \\
\text { próprias }\end{array}$ & -0.424 & 0.082 & -5.17 & 1.291 & 0.165 & 7.82 \\
\hline $\begin{array}{l}\text { Auto Controlo perante as } \\
\text { criticas }\end{array}$ & -0.288 & 0.082 & -3.51 & -0.255 & 0.165 & -1.54 \\
\hline Auto Encorajamento & -0.754 & 0.082 & -9.19 & 1.428 & 0.165 & 8.65 \\
\hline Auto Controlo Emocional & -0.154 & 0.082 & -1.88 & 0.092 & 0.165 & 0.55 \\
\hline Empatia & -0.376 & 0.082 & -4.58 & -0.015 & 0.165 & -0.09 \\
\hline $\begin{array}{l}\text { Compreensão das emoções dos } \\
\text { outros }\end{array}$ & -0.250 & 0.082 & -3.05 & 0.784 & 0.165 & 4.75 \\
\hline
\end{tabular}

\section{Dimensões Motivação}

Valores de Kolmogorov-Smirnov (K-S)

\begin{tabular}{lccr}
\hline \multicolumn{4}{c}{ Tests of Normality } \\
\cline { 2 - 4 } & \multicolumn{4}{c}{ Kolmogorov-Smirnov ${ }^{\mathrm{a}}$} \\
\cline { 2 - 5 } Variedade & Statistic & $\mathrm{df}$ & \multicolumn{1}{c}{ Sig. } \\
Identidade &, 103 & 880 &, 000 \\
Significado &, 091 & 880 &, 000 \\
Autonomia &, 105 & 880 &, 000 \\
Feedback &, 083 & 880 &, 000 \\
a. Lilliefors Significance Correction &, 083 & 880 &, 000 \\
\hline
\end{tabular}


Parâmetros de Normalidade das dimensões da IE

\begin{tabular}{lcccccc}
\hline & Assimetria & $\begin{array}{c}\text { Erropadrão de } \\
\text { Assimetria }\end{array}$ & $A / B$ & $\begin{array}{c}\text { Curtose } \\
(\text { C) }\end{array}$ & $\begin{array}{c}\text { Erropadrão } \\
\text { de Curtose }\end{array}$ & $C / D$ \\
& $($ B) & & $(D)$ & \\
\hline Variedade & -0.636 & 0.82 & $-0,775$ & 0.73 & 0.165 & 4,424 \\
Identidade & 0.042 & 0.82 & 0,051 & -0.258 & 0.165 & $-1,563$ \\
Significado & -0.705 & 0.82 & $-0,859$ & 0.473 & 0.165 & 2,866 \\
Autonomia & -0.388 & 0.82 & $-0,473$ & 0.187 & 0.165 & 1,133 \\
Feedback & -0.280 & 0.82 & $-0,341$ & -0.291 & 0.165 & $-1,763$ \\
\hline
\end{tabular}

Histogramas

Dimensões IE

Compreensão das emoções próprias

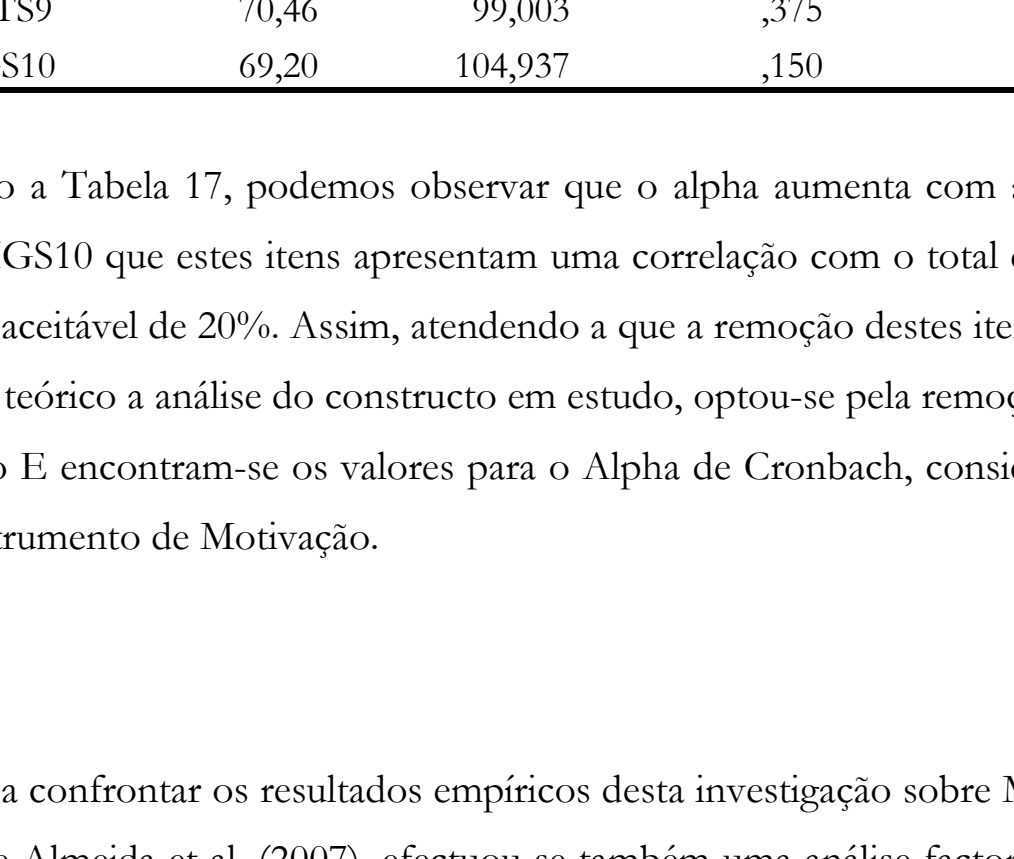


Auto-Controlo perante as críticas

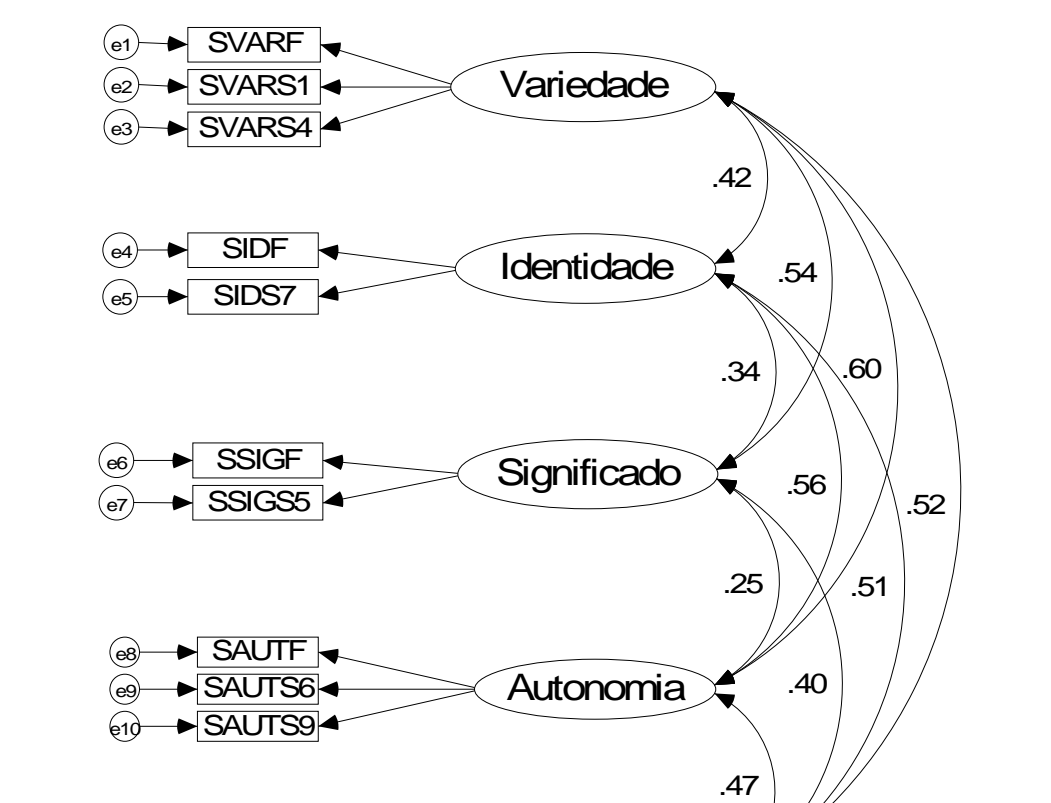

Auto-Encorajamento

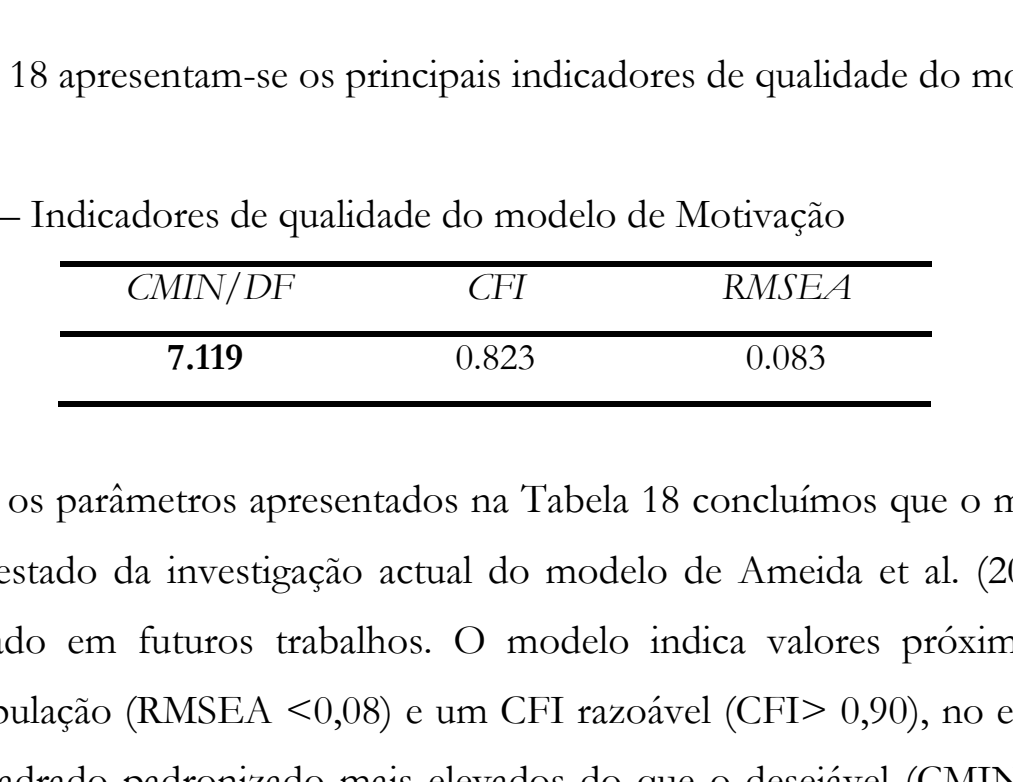


Auto-Controlo Emocional

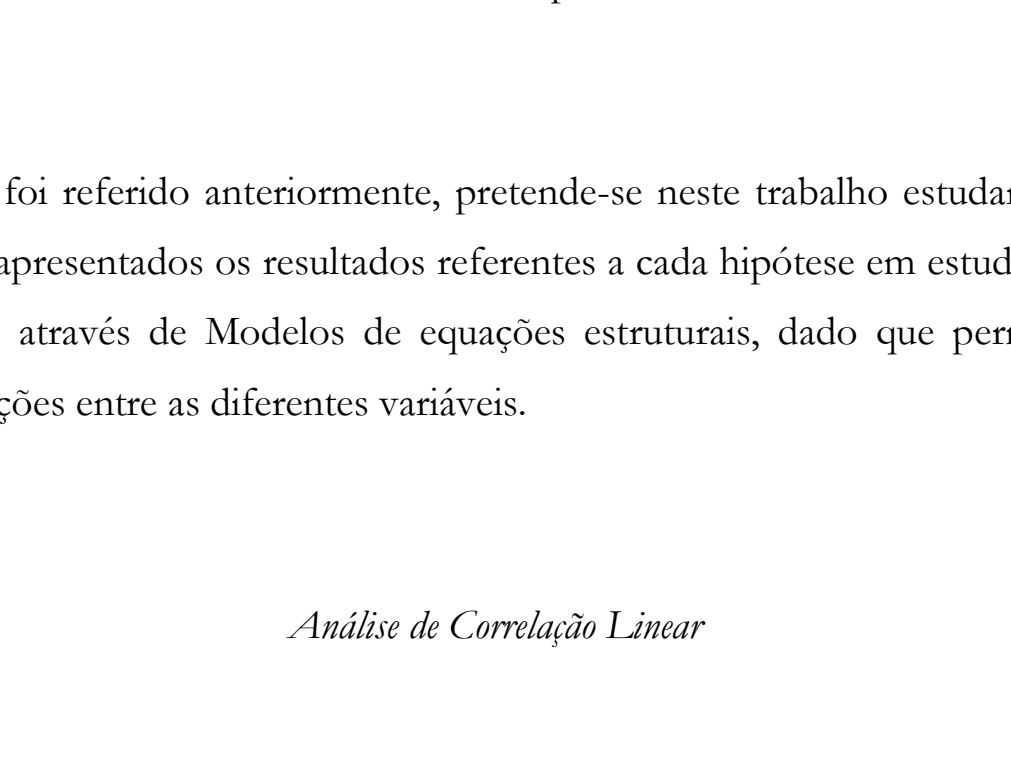

Empatia

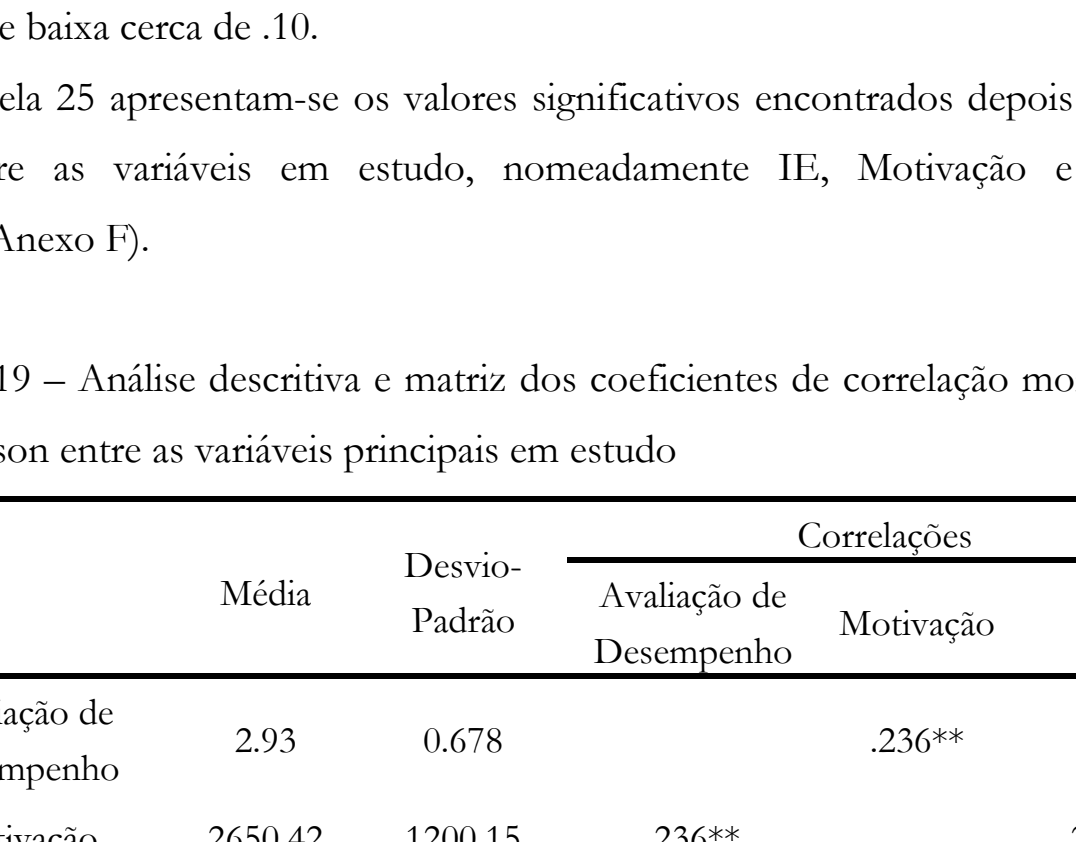


Compreensão das emoções dos outros

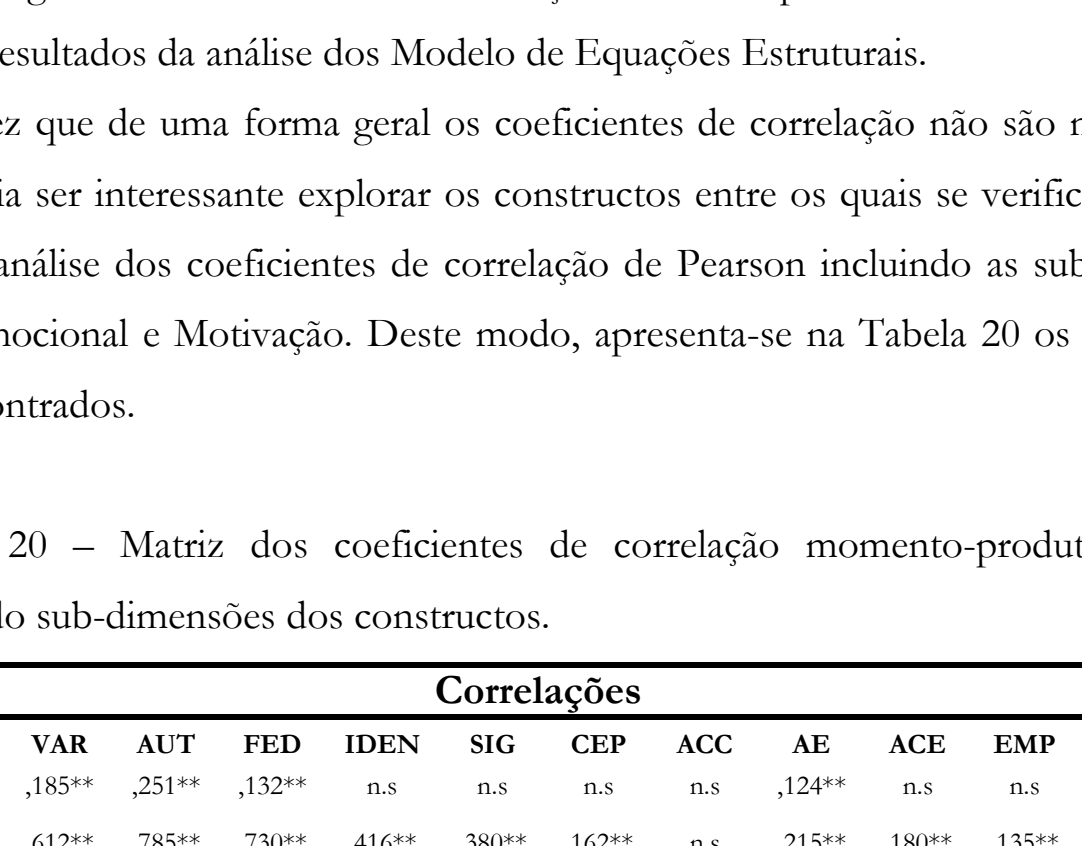

Dimensões Motivação

Variedade

Histograma

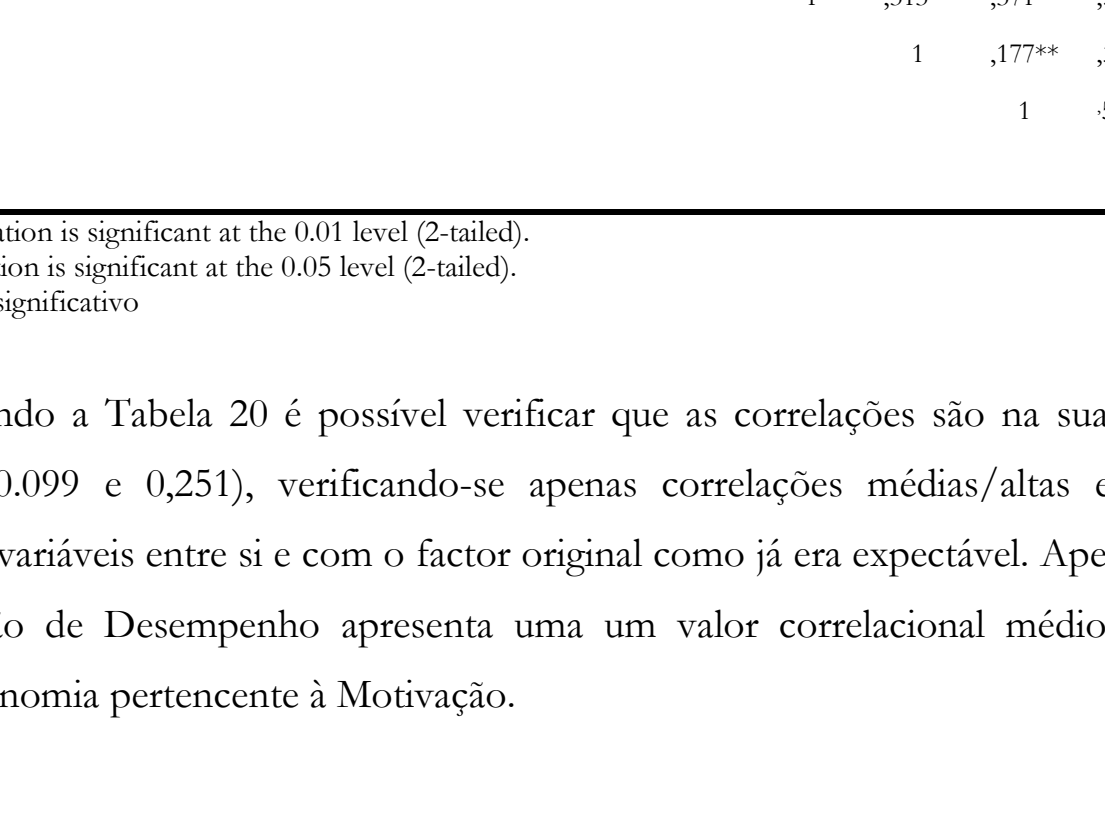


Autonomia

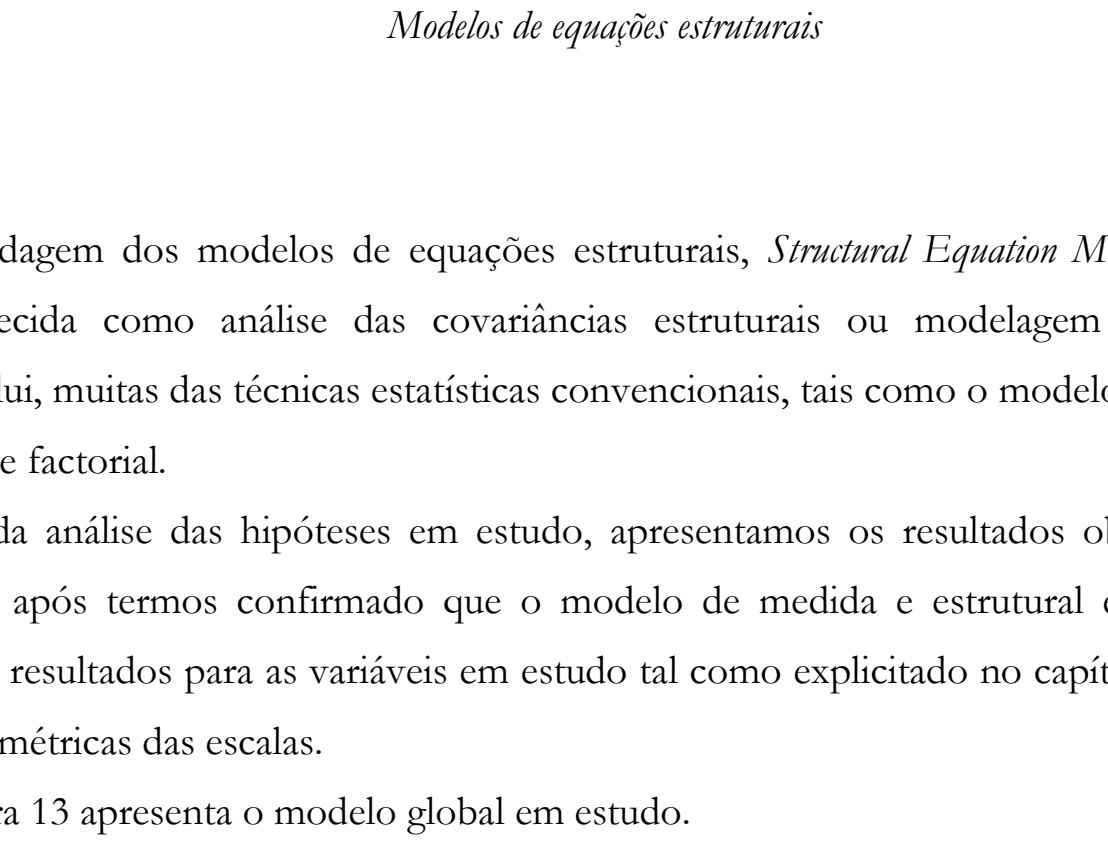

Feedback

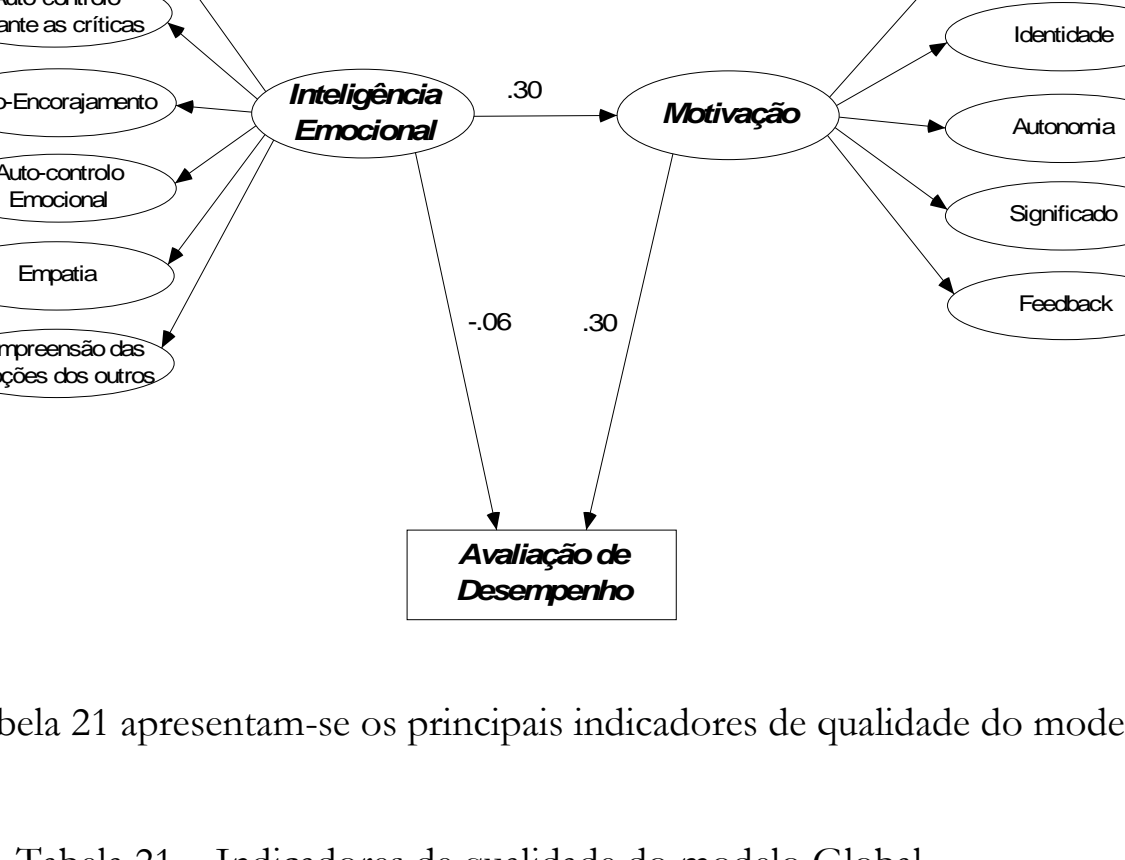


Identidade

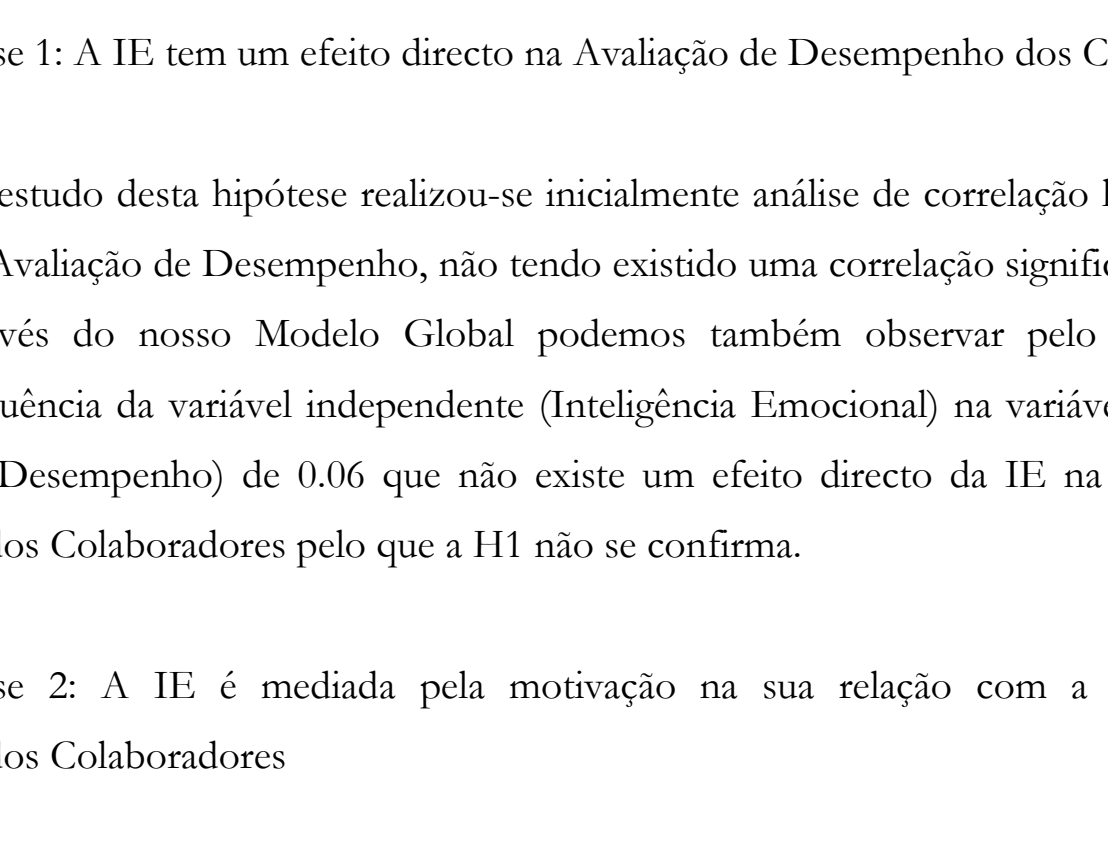

Significado

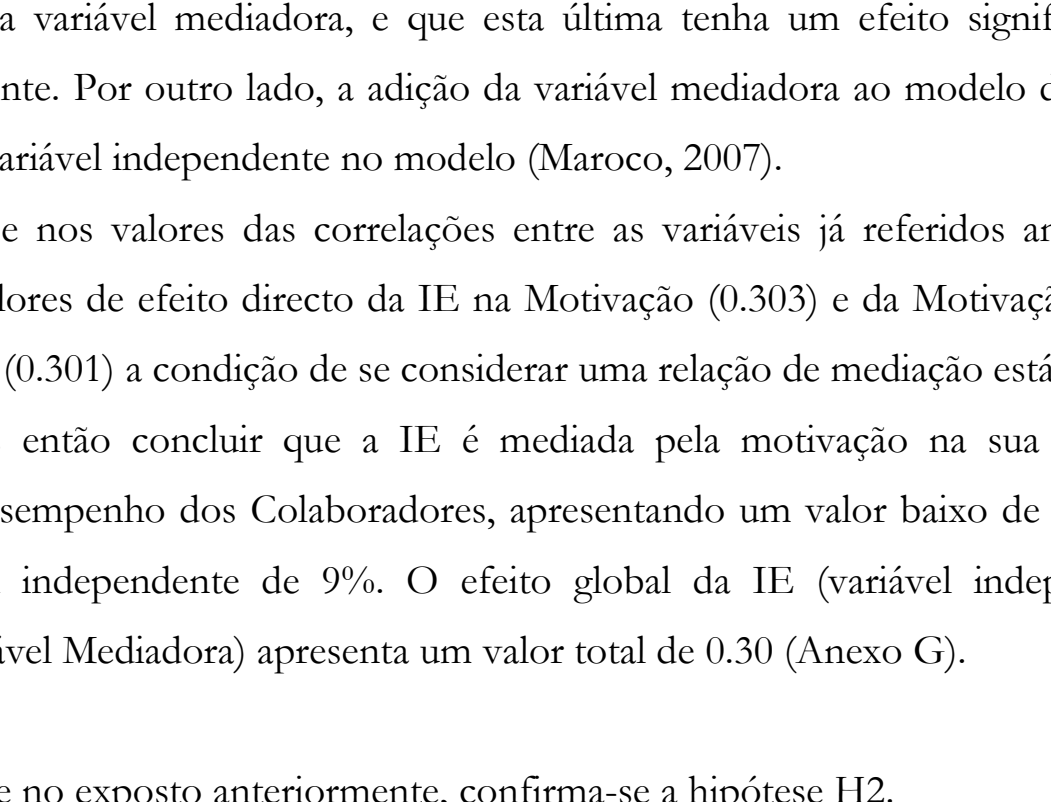


Anexo E

Fidelidade 
Fidelidade dimensões IE:

Compreensão das emoções próprias

\begin{tabular}{|c|c|c|c|}
\hline \multicolumn{4}{|c|}{ Case Processing Summary } \\
\hline & & $\mathrm{N}$ & $\%$ \\
\hline \multirow[t]{3}{*}{ Cases } & Valid & 880 & 100,0 \\
\hline & Excluded $^{a}$ & 0 & 0 \\
\hline & Total & 880 & 100,0 \\
\hline \multicolumn{4}{|c|}{ a. Listwise deletion based on all variables in the procedure. } \\
\hline & \multicolumn{3}{|c|}{ Reliability Statistics } \\
\hline & Alpha de Cronbach & $\mathrm{N}$ of I & \\
\hline & 831 & & 5 \\
\hline
\end{tabular}

\begin{tabular}{|c|c|c|c|c|c|}
\hline \multicolumn{6}{|c|}{ Item-Total Statistics } \\
\hline & $\begin{array}{l}\text { Scale Mean if } \\
\text { Item Deleted }\end{array}$ & $\begin{array}{c}\text { Scale Variance } \\
\text { if Item } \\
\text { Deleted }\end{array}$ & $\begin{array}{l}\text { Corrected } \\
\text { Item-Total } \\
\text { Correlation }\end{array}$ & $\begin{array}{l}\text { Cronbach's } \\
\text { Alpha if Item } \\
\text { Deleted }\end{array}$ & $\begin{array}{l}\text { Scale Mean if } \\
\text { Item Deleted }\end{array}$ \\
\hline IE1 & 19,52 & 7,633 &, 571 &, 366 &, 813 \\
\hline IE10 & 19,73 & 7,104 &, 709 &, 539 & ,775 \\
\hline IE16 & 19,58 & 7,292 & ,726 &, 551 & ,774 \\
\hline IE20 & 19,62 & 7,200 & ,605 & ,377 & 804 \\
\hline IE23 & 19,60 & 6,989 &, 568 & ,335 &, 820 \\
\hline
\end{tabular}

Auto-Controlo Perante as críticas

\begin{tabular}{llrr}
\hline \multicolumn{3}{c}{ Case Processing Summary } \\
\hline \multirow{4}{*}{ Cases } & & $\mathrm{N}$ & $\%$ \\
\cline { 3 - 4 } & Valid & 880 & 100,0 \\
& Excluded $^{\mathrm{a}}$ & 0 &, 0 \\
& Total & 880 & 100,0 \\
\hline a. Listwise deletion based on all variables in the procedure.
\end{tabular}




\begin{tabular}{rr}
\hline \multicolumn{2}{c}{ Reliability Statistics } \\
\hline $\begin{array}{l}\text { Cronbach's } \\
\text { Alpha }\end{array}$ \\
\hline, 756 & 5 \\
\hline
\end{tabular}

\begin{tabular}{lrrrr}
\hline \multicolumn{4}{c}{ Item-Total Statistics } \\
\hline & $\begin{array}{c}\text { Scale Mean if } \\
\text { Item Deleted }\end{array}$ & $\begin{array}{c}\text { Scale Variance } \\
\text { if Item } \\
\text { Deleted }\end{array}$ & $\begin{array}{c}\text { Corrected } \\
\text { Item-Total } \\
\text { Correlation }\end{array}$ & $\begin{array}{c}\text { Cronbach's } \\
\text { Alpha if Item } \\
\text { Deleted }\end{array}$ \\
\cline { 2 - 5 } IE2 & 19,36 & 7,830 &, 509 &, 718 \\
IE8 & 18,50 & 8,897 &, 365 &, 764 \\
IE13 & 18,84 & 8,485 &, 444 &, 739 \\
IE15 & 19,08 & 7,189 &, 599 &, 683 \\
IE21 & 19,10 & 7,066 &, 710 &, 641 \\
\hline
\end{tabular}

Auto-Encorajamento

\begin{tabular}{llrr}
\hline \multicolumn{3}{c}{ Case Processing Summary } \\
\hline \multirow{4}{*}{ Cases } & \multicolumn{2}{c}{ N } & $\%$ \\
\cline { 3 - 4 } & Valid & 880 & 100,0 \\
& Excluded $^{a}$ & 0 &, 0 \\
& Total & 880 & 100,0 \\
\hline a. Listwise deletion based on all variables in the procedure.
\end{tabular}

\begin{tabular}{rr}
\hline \multicolumn{2}{c}{ Reliability Statistics } \\
\hline $\begin{array}{l}\text { Cronbach's } \\
\text { Alpha }\end{array}$ \\
\hline N of Items \\
\hline 795 & 3 \\
\hline
\end{tabular}

\begin{tabular}{lrrrr}
\hline \multicolumn{4}{c}{ Item-Total Statistics } \\
\hline & $\begin{array}{c}\text { Scale Mean if } \\
\text { Item Deleted }\end{array}$ & $\begin{array}{c}\text { Scale Variance } \\
\text { if Item } \\
\text { Deleted }\end{array}$ & $\begin{array}{c}\text { Corrected } \\
\text { Item-Total } \\
\text { Correlation }\end{array}$ & $\begin{array}{c}\text { Cronbach's } \\
\text { Alpha if Item } \\
\text { Deleted }\end{array}$ \\
\cline { 2 - 5 } IE14 & 10,38 & 1,819 &, 634 &, 725 \\
IE19 & 10,16 & 2,118 &, 662 &, 712 \\
IE22 & 10,62 & 1,709 &, 638 &, 727 \\
\hline
\end{tabular}


Auto-Controlo Emocional

\begin{tabular}{|c|c|c|c|}
\hline \multicolumn{4}{|c|}{ Case Processing Summary } \\
\hline \multirow{4}{*}{ Cases } & & $\mathrm{N}$ & $\%$ \\
\hline & Valid & 880 & 100,0 \\
\hline & Excluded $^{\mathrm{a}}$ & 0 & 0 \\
\hline & Total & 880 & 100,0 \\
\hline \multicolumn{4}{|c|}{ Listwise deletion based on all variables in the procedure. } \\
\hline & \multicolumn{2}{|c|}{ Reliability Statistics } & \\
\hline & $\begin{array}{c}\text { Cronbach's } \\
\text { Alpha }\end{array}$ & $\mathrm{N}$ of Items & \\
\hline & ,718 & 3 & \\
\hline
\end{tabular}

\begin{tabular}{lrrrr}
\hline \multicolumn{4}{c}{ Item-Total Statistics } \\
\hline & $\begin{array}{c}\text { Scale Mean if } \\
\text { Item Deleted }\end{array}$ & $\begin{array}{c}\text { Scale Variance } \\
\text { if Item } \\
\text { Deleted }\end{array}$ & $\begin{array}{c}\text { Corrected } \\
\text { Item-Total } \\
\text { Correlation }\end{array}$ & $\begin{array}{c}\text { Cronbach's } \\
\text { Alpha if Item } \\
\text { Deleted }\end{array}$ \\
\cline { 2 - 5 } IE4 & 8,33 & 2,751 &, 551 &, 612 \\
IE6 & 8,44 & 2,659 &, 555 &, 609 \\
IE12 & 8,22 & 3,322 &, 518 &, 658 \\
\hline
\end{tabular}

Empatia

\begin{tabular}{llrr}
\hline \multicolumn{3}{c}{ Case Processing Summary } \\
\hline \multirow{3}{*}{ Cases } & N & $\%$ \\
\cline { 3 - 4 } & Valid & 880 & 100,0 \\
& Excluded $^{\mathrm{a}}$ & 0 &, 0 \\
& Total & 880 & 100,0 \\
\hline a. Listwise deletion based on all variables in the procedure.
\end{tabular}

\begin{tabular}{rr}
\hline \multicolumn{2}{c}{ Reliability Statistics } \\
\hline $\begin{array}{l}\text { Cronbach's } \\
\text { Alpha }\end{array}$ \\
\hline N of Items \\
\hline 566 & 4 \\
\hline
\end{tabular}




\begin{tabular}{lrrrr}
\hline \multicolumn{4}{c}{ Item-Total Statistics } \\
\hline & $\begin{array}{c}\text { Scale Mean if } \\
\text { Item Deleted }\end{array}$ & $\begin{array}{c}\text { Scale Variance } \\
\text { if Item } \\
\text { Deleted }\end{array}$ & $\begin{array}{c}\text { Corrected } \\
\text { Item-Total } \\
\text { Correlation }\end{array}$ & $\begin{array}{c}\text { Cronbach's } \\
\text { Alpha if Item } \\
\text { Deleted }\end{array}$ \\
\cline { 2 - 5 } IE3 & 14,04 & 3,954 &, 485 &, 404 \\
IE5 & 14,00 & 4,215 &, 261 &, 564 \\
IE7 & 14,20 & 3,700 &, 514 &, 369 \\
IE9 & 15,73 & 3,869 &, 217 &, 631 \\
\hline
\end{tabular}

Compreensão das Emoções dos Outros

\begin{tabular}{llrr}
\hline \multicolumn{3}{c}{ Case Processing Summary } \\
\hline \multirow{4}{*}{ Cases } & \multicolumn{2}{c}{$\mathrm{N}$} & $\%$ \\
\cline { 3 - 4 } & Valid & 880 & 100,0 \\
& Excluded $^{a}$ & 0 &, 0 \\
& Total & 880 & 100,0 \\
\hline a. Listwise deletion based on all variables in the procedure.
\end{tabular}

a. Listwise deletion based on all variables in the procedure.

\begin{tabular}{rr}
\hline \multicolumn{2}{c}{ Reliability Statistics } \\
\hline $\begin{array}{l}\text { Cronbach's } \\
\text { Alpha }\end{array}$ \\
\hline, 758 & 3 \\
\hline
\end{tabular}

\begin{tabular}{lrrrr}
\hline \multicolumn{4}{c}{ Item-Total Statistics } \\
\hline & $\begin{array}{c}\text { Scale Mean if } \\
\text { Item Deleted }\end{array}$ & $\begin{array}{c}\text { Scale Variance } \\
\text { if Item } \\
\text { Deleted }\end{array}$ & $\begin{array}{c}\text { Corrected } \\
\text { Item-Total } \\
\text { Correlation }\end{array}$ & $\begin{array}{c}\text { Cronbach's } \\
\text { Alpha if Item } \\
\text { Deleted }\end{array}$ \\
\cline { 2 - 5 } IE11 & 9,41 & 1,929 &, 554 &, 714 \\
IE17 & 9,51 & 1,760 &, 655 &, 597 \\
IE18 & 9,68 & 1,936 &, 557 &, 710 \\
\hline
\end{tabular}


Fidelidade dimensões Motivação:

Autonomia

\begin{tabular}{llrr}
\hline \multicolumn{3}{c}{ Case Processing Summary } \\
\hline \multirow{4}{*}{ Cases } & \multicolumn{2}{c}{ N } & $\%$ \\
\cline { 3 - 4 } & Valid & 880 & 100,0 \\
& Excluded $^{\text {a }}$ & 0 &, 0 \\
& Total & 880 & 100,0 \\
\hline a. Listwise deletion based on all variables in the procedure.
\end{tabular}

\begin{tabular}{rr}
\hline \multicolumn{2}{c}{ Reliability Statistics } \\
\hline $\begin{array}{l}\text { Cronbach's } \\
\text { Alpha }\end{array}$ \\
\hline, 641 & 3 \\
\hline
\end{tabular}

\begin{tabular}{lrrrr}
\hline \multicolumn{5}{c}{ Item-Total Statistics } \\
\hline & $\begin{array}{c}\text { Scale Mean if } \\
\text { Item Deleted }\end{array}$ & $\begin{array}{c}\text { Scale Variance } \\
\text { if Item } \\
\text { Deleted }\end{array}$ & $\begin{array}{c}\text { Corrected } \\
\text { Item-Total } \\
\text { Correlation }\end{array}$ & $\begin{array}{c}\text { Cronbach's } \\
\text { Alpha if Item } \\
\text { Deleted }\end{array}$ \\
\cline { 2 - 6 } SAUTF & 9,63 & 6,848 &, 556 &, 437 \\
SAUTS6 & 8,80 & 5,946 &, 411 &, 613 \\
SAUTS9 & 9,41 & 6,368 &, 416 &, 593 \\
\hline
\end{tabular}

Identidade

\begin{tabular}{llrr}
\hline \multicolumn{3}{c}{ Case Processing Summary } \\
\hline \multirow{4}{*}{ Cases } & Valid & 880 & $\%$ \\
\cline { 2 - 3 } & Excluded $^{\mathrm{a}}$ & 0 & 100,0 \\
& Total & 880 & 100,0 \\
\hline a. Listwise deletion based on all variables in the procedure.
\end{tabular}




\begin{tabular}{rr}
\hline \multicolumn{2}{c}{ Reliability Statistics } \\
\hline $\begin{array}{l}\text { Cronbach's } \\
\text { Alpha }\end{array}$ \\
\hline, 430 & 3 \\
\hline
\end{tabular}

\begin{tabular}{lrrrr}
\hline \multicolumn{4}{c}{ Item-Total Statistics } \\
\hline & $\begin{array}{c}\text { Scale Mean if } \\
\text { Item Deleted }\end{array}$ & $\begin{array}{c}\text { Scale Variance } \\
\text { if Item } \\
\text { Deleted }\end{array}$ & $\begin{array}{c}\text { Corrected } \\
\text { Item-Total } \\
\text { Correlation }\end{array}$ & $\begin{array}{c}\text { Cronbach's } \\
\text { Alpha if Item } \\
\text { Deleted }\end{array}$ \\
\cline { 2 - 5 } SIDF & 9,06 & 7,275 &, 244 &, 373 \\
SIDS2 & 9,74 & 4,843 &, 266 &, 343 \\
SIDS7 & 8,79 & 5,897 &, 289 &, 280 \\
\hline
\end{tabular}

Variedade

\begin{tabular}{llrr}
\hline \multicolumn{3}{c}{ Case Processing Summary } \\
\hline \multirow{4}{*}{ Cases } & \multicolumn{1}{c}{ N } & $\%$ \\
\cline { 3 - 4 } & Valid & 880 & 100,0 \\
& Excluded $^{\mathrm{a}}$ & 0 &, 0 \\
& Total & 880 & 100,0 \\
\hline a. Listwise deletion based on all variables in the procedure.
\end{tabular}

\begin{tabular}{rr}
\hline \multicolumn{2}{c}{ Reliability Statistics } \\
\hline $\begin{array}{l}\text { Cronbach's } \\
\text { Alpha }\end{array}$ & N of Items \\
\hline, 632 & 3 \\
\hline
\end{tabular}

\begin{tabular}{lrrrr}
\hline \multicolumn{4}{c}{ Item-Total Statistics } \\
\hline & $\begin{array}{c}\text { Scale Mean if } \\
\text { Item Deleted }\end{array}$ & $\begin{array}{c}\text { Scale Variance } \\
\text { if Item } \\
\text { Deleted }\end{array}$ & $\begin{array}{c}\text { Corrected } \\
\text { Item-Total } \\
\text { Correlation }\end{array}$ & $\begin{array}{c}\text { Cronbach's } \\
\text { Alpha if Item } \\
\text { Deleted }\end{array}$ \\
\cline { 2 - 5 } SVARF & 10,89 & 5,527 &, 520 &, 413 \\
SVARS1 & 10,38 & 8,161 &, 373 &, 627 \\
SVARS4 & 10,65 & 5,722 &, 456 &, 517 \\
\hline
\end{tabular}


Significado

\begin{tabular}{llrr}
\hline \multicolumn{3}{c}{ Case Processing Summary } \\
\hline \multirow{4}{*}{ Cases } & \multicolumn{1}{c}{ N } & $\%$ \\
\cline { 3 - 4 } & Valid & 880 & 100,0 \\
& Excluded $^{\mathrm{a}}$ & 0 &, 0 \\
& Total & 880 & 100,0 \\
\hline a. Listwise deletion based on all variables in the procedure.
\end{tabular}

\begin{tabular}{|c|c|}
\hline \multicolumn{2}{|c|}{ Reliability Statistics } \\
\hline $\begin{array}{c}\text { Cronbach's } \\
\text { Alpha }\end{array}$ & $\mathrm{N}$ of Items \\
\hline ,329 & 3 \\
\hline
\end{tabular}

\begin{tabular}{lrrrr}
\hline \multicolumn{5}{c}{ Item-Total Statistics } \\
\hline & $\begin{array}{c}\text { Scale Mean if } \\
\text { Item Deleted }\end{array}$ & $\begin{array}{c}\text { Scale Variance } \\
\text { if Item } \\
\text { Deleted }\end{array}$ & $\begin{array}{c}\text { Corrected } \\
\text { Item-Total } \\
\text { Correlation }\end{array}$ & $\begin{array}{c}\text { Cronbach's } \\
\text { Alpha if Item } \\
\text { Deleted }\end{array}$ \\
\cline { 2 - 5 } SSIGF & 10,98 & 5,863 &, 250 &, 120 \\
SSIGS5 & 10,96 & 5,623 &, 272 &, 070 \\
SSIGS10 & 10,41 & 6,575 &, 062 &, 511 \\
\hline
\end{tabular}

Feedback

\begin{tabular}{llrr}
\hline \multicolumn{3}{c}{ Case Processing Summary } \\
\hline \multirow{4}{*}{ Cases } & \multicolumn{1}{c}{ N } & $\%$ \\
\cline { 3 - 4 } & Valid & 880 & 100,0 \\
& Excluded $^{\mathrm{a}}$ & 0 &, 0 \\
& Total & 880 & 100,0 \\
\hline a. Listwise deletion based on all variables in the procedure.
\end{tabular}

\begin{tabular}{rr}
\hline \multicolumn{2}{c}{ Reliability Statistics } \\
\hline $\begin{array}{l}\text { Cronbach's } \\
\text { Alpha }\end{array}$ \\
\hline \multicolumn{2}{|c|}{ N of Items } \\
\hline
\end{tabular}




\begin{tabular}{lrrrr}
\hline \multicolumn{4}{c}{ Item-Total Statistics } \\
\hline & $\begin{array}{c}\text { Scale Mean if } \\
\text { Item Deleted }\end{array}$ & $\begin{array}{c}\text { Scale Variance } \\
\text { if Item } \\
\text { Deleted }\end{array}$ & $\begin{array}{c}\text { Corrected } \\
\text { Item-Total } \\
\text { Correlation }\end{array}$ & $\begin{array}{c}\text { Cronbach's } \\
\text { Alpha if Item } \\
\text { Deleted }\end{array}$ \\
\cline { 2 - 5 } SFEDF & 9,99 & 5,886 &, 418 &, 207 \\
SFEDS3 & 10,02 & 7,027 &, 249 &, 487 \\
SFEDS8 & 10,22 & 6,059 &, 273 &, 462 \\
\hline
\end{tabular}


Anexo F

Validade 
Inteligência Emocional

Análise Factorial Confirmatória

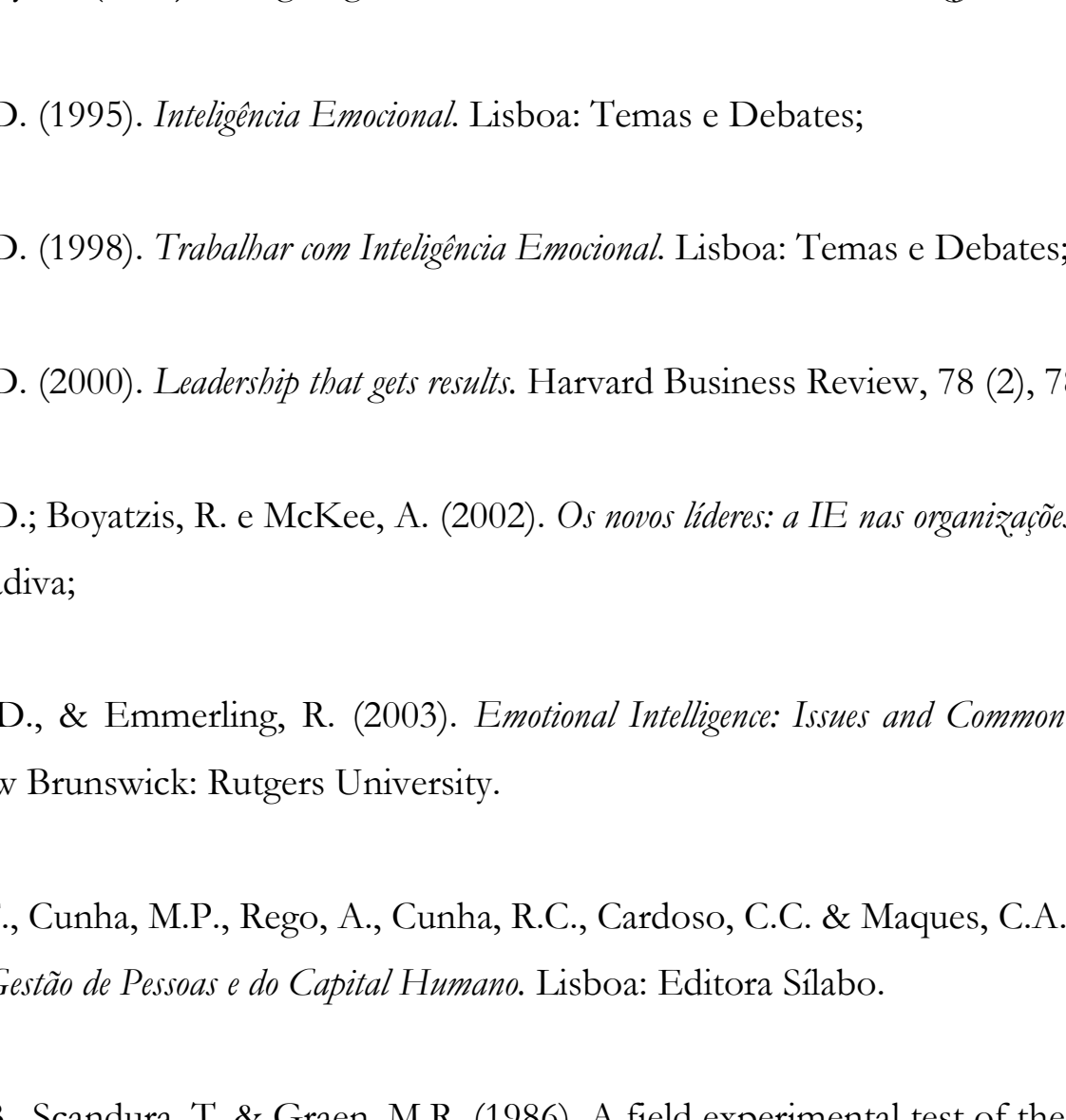


Regression Weights: (Group number 1 - Default model)

\begin{tabular}{|c|c|c|c|c|c|c|c|}
\hline & & & Estimate & S.E. & C.R. & $\mathrm{P}$ & Label \\
\hline IE12_1 & $<---$ & Auto-Controlo Emocional &, 871 & ,060 & 14,527 & $* * *$ & \\
\hline IE6_1 & $<---$ & Auto-Controlo Emocional & 1,046 & 072 & 14,436 & *** & \\
\hline IE4_1 & $<---$ & Auto-Controlo Emocional & 1,000 & & & & \\
\hline IE18_1 & $<---$ & Compreensão das emoções dos outros & ,956 & ,055 & 17,224 & $* * *$ & \\
\hline IE17_1 & $<---$ & Compreensão das emoções dos outros & 1,149 & ,058 & 19,698 & *** & \\
\hline IE11_1 & $<---$ & Compreensão das emoções dos outros & 1,000 & & & & \\
\hline IE22_1 & $<---$ & Auto-Encorajamento & 1,000 & & & & \\
\hline IE19_1 & $<---$ & Auto-Encorajamento &, 790 & ,039 & 20,403 & $* * *$ & \\
\hline IE14_1 & $<---$ & Auto-Encorajamento & ,922 & 046 & 19,883 & $* * *$ & \\
\hline IE16_1 & $<---$ & Compreensão das Emoções Próprias & 1,000 & & & & \\
\hline IE10_1 & $<---$ & Compreensão das Emoções Próprias & 1,022 & ,039 & 26,225 & $* * *$ & \\
\hline IE1_1 & $<---$ & Compreensão das Emoções Próprias & ,825 & 041 & 20,208 & $* * *$ & \\
\hline IE7_1 & $<---$ & Empatia & 2,223 & 248 & 8,956 & $* * *$ & \\
\hline IE5_1 & $<---$ & Empatia & 1,000 & & & & \\
\hline IE3_1 & $<---$ & Empatia & 1,940 & 217 & 8,925 & $* * *$ & \\
\hline IE13_1 & $<---$ & Auto-Controle perante as Críticas & 1,000 & & & & \\
\hline IE8_1 & $<---$ & Auto-Controle perante as Críticas &, 843 & ,090 & 9,401 & $* * *$ & \\
\hline IE2_1 & $<---$ & Auto-Controle perante as Críticas & 1,426 & 117 & 12,144 & $* * *$ & \\
\hline IE15_1 & $<---$ & Auto-Controle perante as Críticas & 1,754 & 135 & 13,034 & $* * *$ & \\
\hline IE21_1 & $<---$ & Auto-Controle perante as Críticas & 1,954 & 144 & 13,616 & $* * *$ & \\
\hline IE20_1 & $<---$ & Compreensão das Emoções Próprias &, 898 & 044 & 20,172 & $* * *$ & \\
\hline IE23_1 & $<---$ & Compreensão das Emoções Próprias & ,928 & 050 & 18,721 & $* * *$ & \\
\hline IE9_1 & $<--$ & Empatia & ,972 & , 166 & 5,864 & $* * *$ & \\
\hline
\end{tabular}

Standardized Regression Weights: (Group number 1 - Default model)

\begin{tabular}{lllr}
\hline & & & Estimate \\
\hline IE12_1 & $<---$ & Auto-Controlo_Emocional &, 691 \\
IE6_1 & $<---$ & Auto-Controlo_Emocional &, 679 \\
IE4_1 & $<---$ & Auto-Controlo_Emocional &, 667 \\
IE18_1 & $<---$ & Compreensão das emoções_dos outros &, 668 \\
IE17_1 & $<---$ & Compreensão das emoções_dos outros &, 794 \\
IE11_1 & $<---$ & Compreensão das emoções_dos outros &, 694 \\
IE22_1 & $<---$ & Auto-Encorajamento &, 763 \\
IE19_1 & $<---$ & Auto-Encorajamento &, 768 \\
IE14_1 & $<---$ & Auto-Encorajamento &, 741 \\
IE16_1 & $<---$ & Compreensão das_Emoções Próprias &, 842 \\
IE10_1 & $<---$ & Compreensão das_Emoções Próprias &, 802 \\
IE1_1 & $<---$ & Compreensão das_Emoções Próprias &, 651 \\
IE7_1 & $<---$ & Empaty &, 819 \\
IE5_1 & $<---$ & Empaty &, 334 \\
IE3_1 & $<---$ & Empaty &, 769 \\
IE13_1 & $<---$ & Auto-Controle_perante as Críticas &, 478 \\
IE8_1 & $<---$ & Auto-Controle_perante as Críticas &, 408 \\
IE2_1 & $<---$ & Auto-Controle_perante as Críticas &, 621 \\
IE15_1 & $<---$ & Auto-Controle_perante as Críticas &, 725 \\
IE21_1 & $<---$ & Auto-Controle_perante as Críticas &, 875 \\
IE20_1 & $<---$ & Compreensão das_Emoções Próprias &, 650 \\
IE23_1 & $<---$ & Compreensão das_Emoções Próprias &, 611 \\
IE9_1 & $<---$ & Empaty &, 270 \\
\hline
\end{tabular}


Model Fit Summary- IE 23 itens

\section{CMIN}

\begin{tabular}{lrrrrr}
\hline Model & NPAR & CMIN & DF & P & CMIN/DF \\
\hline Default model & 84 & 528,830 & 215 &, 000 & 2,460 \\
Saturated model & 299 &, 000 & $\underline{0}$ & & \\
Independence model & 46 & 7275,442 & 253 &, 000 & 28,757 \\
\hline
\end{tabular}

Baseline Comparisons

\begin{tabular}{lrrrrr}
\hline Model & $\begin{array}{r}\text { NFI } \\
\text { Delta1 }\end{array}$ & $\begin{array}{r}\text { RFI } \\
\text { rho1 }\end{array}$ & $\begin{array}{r}\text { IFI } \\
\text { Delta2 }\end{array}$ & $\begin{array}{r}\text { TLI } \\
\text { rho2 }\end{array}$ & CFI \\
\hline Default model &, 927 &, 914 &, 956 &, 947 &, 955 \\
Saturated model & 1,000 & & 1,000 & & 1,000 \\
Independence model &, 000 &, 000 &, 000 &, 000 &, 000 \\
\hline
\end{tabular}

Parsimony-Adjusted Measures

\begin{tabular}{lrrr}
\hline Model & PRATIO & PNFI & PCFI \\
\hline Default model &, 850 &, 788 &, 812 \\
Saturated model &, 000 &, 000 &, 000 \\
Independence model & 1,000 &, 000 &, 000 \\
\hline
\end{tabular}

RMSEA

\begin{tabular}{lrrrr}
\hline Model & RMSEA & LO 90 & HI 90 & PCLOSE \\
\hline Default model &, 041 &, 036 &, 045 & 1,000 \\
Independence model &, 178 &, 174 &, 181 &, 000 \\
\hline
\end{tabular}


Motivação

Análise Factorial Confirmatória
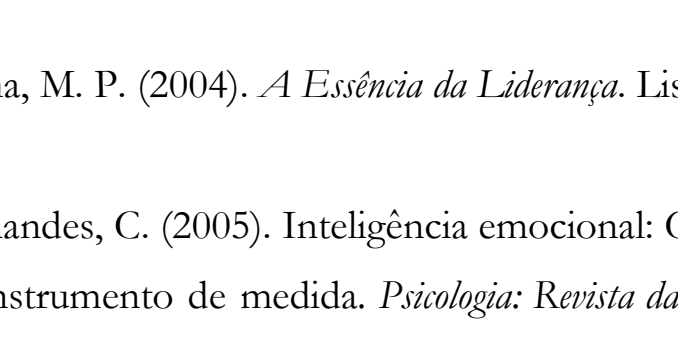

Identidade

.42

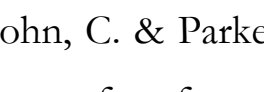

Significado

.34

Autonomia

.40

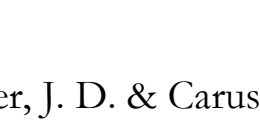

.25

.56

.52

.47

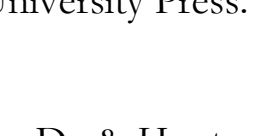

Feedlback

(13) SFEDS8

Regression Weights: (Group number 1 - Default model)

\begin{tabular}{lllrllll}
\hline & & & Estimate & S.E. & C.R. & P & Label \\
\hline SVARS4_1 & $<---$ & Variedad & 1,000 & & & & \\
SVARS1_1 & $<---$ & Variedad &, 670 &, 060 & 11,079 & $* * *$ & par_1 \\
SVARF3_1 & $<---$ & Variedad & 1,282 &, 101 & 12,750 & $* * *$ & par_2 \\
SIDS7_1 & $<---$ & Identidad & 1,000 & & & & \\
SIDF2_1 & $<---$ & Identidad &, 997 &, 166 & 5,997 & $* * *$ & par_3 \\
SAUTS9_1 & $<---$ & Autonomi & 1,000 & & & & \\
SAUTS6_1 & $<---$ & Autonomi & 1,140 &, 096 & 11,879 & $* * *$ & par_4 \\
SAUTF1_1 & $<---$ & Autonomi & 1,042 &, 083 & 12,486 & $* * *$ & par_5 \\
SFEDS8_1 & $<---$ & Feedbac & 1,000 & & & & \\
SFEDS3_1 & $<---$ & Feedbac &, 766 &, 103 & 7,457 & $* * *$ & par_6 \\
SFEDF5_1 & $<---$ & Feedbac & 1,379 &, 162 & 8,523 & $* * *$ & par_7 \\
SSIGS5_1 & $<---$ & Signific & 1,000 & & & & \\
SSIGF4_1 & $<---$ & Signific & 1,650 &, 248 & 6,658 & $* * *$ & par_14 \\
\hline
\end{tabular}


Standardized Regression Weights: (Group number 1 - Default model)

\begin{tabular}{lllr}
\hline & & & Estimate \\
\hline SVARS4_1 & $<---$ & Variedad &, 568 \\
SVARS1_1 & $<---$ & Variedad &, 524 \\
SVARF3_1 & $<---$ & Variedad &, 746 \\
SIDS7_1 & $<---$ & Identidad &, 414 \\
SIDF2_1 & $<---$ & Identidad &, 512 \\
SAUTS9_1 & $<---$ & Autonomi &, 565 \\
SAUTS6_1 & $<---$ & Autonomi &, 603 \\
SAUTF1_1 & $<---$ & Autonomi &, 730 \\
SFEDS8_1 & $<---$ & Feedbac &, 455 \\
SFEDS3_1 & $<---$ & Feedbac &, 395 \\
SFEDF5_1 & $<---$ & Feedbac &, 705 \\
SSIGS5_1 & $<---$ & Signific &, 452 \\
SSIGF4_1 & $<---$ & Signific &, 759 \\
\hline
\end{tabular}

Model Fit Summary- Motivação 13 itens

\section{CMIN}

\begin{tabular}{lrrrrr}
\hline Model & NPAR & CMIN & DF & P & CMIN/DF \\
\hline Default model & 49 & 391,541 & 55 &, 000 & 7,119 \\
Saturated model & 104 &, 000 & 0 & & \\
Independence model & 26 & 1979,747 & 78 &, 000 & 25,381 \\
\hline
\end{tabular}

Baseline Comparisons

\begin{tabular}{llllll}
\hline Model & NFI & RFI & IFI & TLI & CFI \\
& Delta1 & rho1 & $\begin{array}{l}\text { Delta2 } \\
\text { rho2 }\end{array}$ & \\
\hline Default model &, 802 &, 720 &, 825 &, 749 &, 823 \\
Saturated model & 1,000 & & 1,000 & & 1,000 \\
Independence model &, 000 &, 000 &, 000 &, 000 &, 000 \\
\hline
\end{tabular}

Parsimony-Adjusted Measures

\begin{tabular}{llll}
\hline Model & PRATIO & PNFI & PCFI \\
\hline Default model &, 705 &, 566 &, 580 \\
Saturated model &, 000 &, 000 &, 000 \\
Independence model & 1,000 &, 000 &, 000 \\
\hline
\end{tabular}

RMSEA

\begin{tabular}{lllll}
\hline Model & RMSEA & LO 90 & HI 90 & PCLOSE \\
\hline Default model &, 083 &, 076 &, 091 &, 000 \\
Independence model &, 167 &, 160 &, 173 &, 000 \\
\hline
\end{tabular}


Anexo G

Modelo de Equações Estruturais 
Standardized Total Effects (Global - Default model)

\begin{tabular}{|c|c|c|c|c|c|c|c|c|c|c|c|c|c|}
\hline & $I E$ & $M O T$ & $\mathrm{CEO}$ & EMPT & $A C E$ & $A E$ & CEP & $A C P C$ & $A U T$ & $S I G$ & FED & $I D$ & $V A R$ \\
\hline MOT & ,303 & ,000 & ,000 & ,000 & ,000 & ,000 & ,000 & ,000 & ,000 & ,000 & ,000 & ,000 & ,000 \\
\hline $\mathrm{EO}$ & 911 & 000 & ,000 & ,000 & ,000 & ,000 & ,000 & ,000 & ,000 & ,000 & ,000 & ,000 & ,000 \\
\hline EMP & 697 & ,000 & ,000 & ,000 & ,000 & ,000 & 000 & ,000 & ,000 & ,000 & 000 & 000 & ,000 \\
\hline ACE & ,550 & 000 & ,000 & ,000 & 000 & ,000 & 000 & 000 & ,000 & ,000 & 000 & 000 & ,000 \\
\hline $\mathrm{AE}$ & ,750 & ,000 & ,000 &, 000 & 000 & ,000 & 000 & 000 &, 000 & ,000 & ,000 & 000 & ,000 \\
\hline CEP & ,786 & 000 & ,000 & ,000 & ,000 & ,000 & 000 & ,000 & ,000 & ,000 & ,000 & 000 & ,000 \\
\hline AC & 494 & ,000 & ,000 & ,000 & 000 & ,000 & 000 & ,000 & ,000 & ,000 & ,000 & 000 & ,000 \\
\hline AUT & 212 & ,702 & 000 & ,000 & 000 & ,000 & 000 & 000 & ,000 & ,000 & 000 & 000 & ,000 \\
\hline SIG & 169 &, 558 &, 000 & 000 & 000 & ,000 & 000 & ,000 &, 000 & ,000 & ,000 & ,000 & ,000 \\
\hline FED & 202 & 666 & ,000 & ,000 & ,000 & ,000 & 000 & ,000 & ,000 & ,000 & ,000 & ,000 & ,000 \\
\hline ID & 183 & 604 & ,000 & ,000 & ,000 & ,000 & ,000 &, 000 & ,000 & ,000 & ,000 & ,000 & ,000 \\
\hline VAR & ,254 & ,838 & ,000 & ,000 & ,000 & ,000 & ,000 & ,000 & ,000 & ,000 & ,000 & ,000 & ,000 \\
\hline IE9_1 & 184 & 000 & ,000 & ,265 & ,000 & ,000 & ,000 & ,000 & ,000 & ,000 & ,000 & 000 & ,000 \\
\hline IE21_1 & ,430 & ,000 & ,000 & ,000 & ,000 & ,000 & ,000 & ,871 & ,000 & ,000 & ,000 & ,000 & ,000 \\
\hline IE15_1 & ,359 & ,000 &, 000 & ,000 & ,000 & ,000 & ,000 & ,727 & ,000 & ,000 & ,000 & ,000 & ,000 \\
\hline IE23_1 & ,482 & ,000 & ,000 & ,000 & ,000 & ,000 & 613 & ,000 & ,000 & ,000 & ,000 & ,000 & ,000 \\
\hline IE20_1 & ,511 & ,000 & ,000 & ,000 & ,000 & ,000 & 651 & ,000 & ,000 & ,000 & ,000 & ,000 &, 000 \\
\hline IE11_1 & ,641 & ,000 &, 704 & ,000 & ,000 & ,000 & ,000 & ,000 &, 000 & ,000 & ,000 & ,000 & ,000 \\
\hline IE17_1 & ,717 &, 000 &, 787 &, 000 &, 000 & ,000 & ,000 & ,000 & ,000 & ,000 & ,000 & ,000 & ,000 \\
\hline IE18_1 & 606 &, 000 & 665 & ,000 & ,000 & ,000 & ,000 & ,000 & ,000 & ,000 & ,000 & ,000 & ,000 \\
\hline IE3_1 & ,537 & ,000 &, 000 & ,771 & 000 & ,000 & ,000 & 000 & ,000 & ,000 & ,000 & ,000 & ,000 \\
\hline IE5_1 & ,228 & ,000 & ,000 & ,327 &, 000 & ,000 & ,000 & ,000 &, 000 & ,000 & ,000 & ,000 & ,000 \\
\hline IE7_1 &, 572 &, 000 &, 000 &, 821 &, 000 &, 000 &, 000 &, 000 &, 000 &, 000 &, 000 &, 000 & ,000 \\
\hline IE4_1 & ,367 & ,000 & ,000 & ,000 & 668 & ,000 & ,000 & ,000 & ,000 & ,000 & ,000 & ,000 &, 000 \\
\hline IE6_1 &, 374 & ,000 & ,000 & ,000 & 680 & ,000 & ,000 &, 000 &, 000 & ,000 & ,000 & ,000 & ,000 \\
\hline IE12_1 & ,379 &, 000 & ,000 &, 000 & 689 & ,000 & ,000 & ,000 &, 000 & ,000 & ,000 & ,000 & ,000 \\
\hline IE14_1 & ,555 & ,000 &, 000 & ,000 & ,000 & ,739 & ,000 & ,000 & ,000 & ,000 & ,000 & ,000 & ,000 \\
\hline IE19_1 & ,577 & ,000 &, 000 & ,000 & ,000 & ,769 & ,000 & 000 & ,000 & ,000 & ,000 & ,000 & ,000 \\
\hline IE22_1 & ,573 &, 000 & ,000 & ,000 &, 000 & ,764 &, 000 & ,000 & ,000 & ,000 & ,000 & ,000 & ,000 \\
\hline IE16_1 & ,660 & ,000 &, 000 & ,000 & ,000 & ,000 & ,841 & ,000 & ,000 & ,000 & ,000 & ,000 & ,000 \\
\hline IE10_1 & ,630 & ,000 & ,000 & ,000 & ,000 & ,000 & ,802 & ,000 & ,000 & ,000 & ,000 & ,000 & ,000 \\
\hline IE1_1 & ,512 & ,000 & ,000 & ,000 & ,000 & ,000 & ,652 & ,000 & ,000 & ,000 & ,000 & ,000 & ,000 \\
\hline IE2_1 & ,307 & ,000 &, 000 & ,000 & ,000 & ,000 &, 000 & 621 & ,000 & ,000 & ,000 & ,000 & ,000 \\
\hline IE8_1 & 202 & ,000 & ,000 & ,000 & ,000 & ,000 &, 000 & ,409 & ,000 & ,000 & ,000 & ,000 & ,000 \\
\hline IE13_1 & ,238 & ,000 & ,000 & ,000 & ,000 & ,000 & ,000 & ,482 & ,000 & ,000 & ,000 & ,000 & ,000 \\
\hline SAUTS9_1 & 119 & ,392 & ,000 & ,000 & 000 & ,000 &, 000 & ,000 & ,559 & ,000 & ,000 & ,000 &, 000 \\
\hline SAUTS6_1 & ,127 & ,421 & ,000 & ,000 & ,000 & ,000 & ,000 &, 000 & ,599 & ,000 & ,000 & ,000 & ,000 \\
\hline SAUTF1_1 & ,158 &, 521 &, 000 & ,000 & ,000 & ,000 & ,000 &, 000 &, 742 & ,000 & ,000 & ,000 & ,000 \\
\hline SSIGS5_1 & ,079 & 260 &, 000 & ,000 & ,000 & ,000 & ,000 & ,000 & ,000 & ,466 & ,000 & ,000 & ,000 \\
\hline SSIGF4_1 & ,124 & ,411 &, 000 & ,000 & ,000 & ,000 &, 000 & ,000 & ,000 & ,736 & ,000 & ,000 & ,000 \\
\hline SFEDS8_1 & ,091 & ,301 &, 000 & ,000 & ,000 & ,000 &, 000 &, 000 & ,000 & ,000 & ,452 &, 000 & ,000 \\
\hline SFEDS3_1 & ,079 & ,261 &, 000 & ,000 & ,000 & ,000 & ,000 &, 000 & ,000 & ,000 & ,391 &, 000 & ,000 \\
\hline SFEDF5_1 & ,144 & ,475 &, 000 & ,000 & ,000 & ,000 &, 000 & ,000 & ,000 & ,000 & ,713 &, 000 & ,000 \\
\hline SIDS7_1 & 070 & ,231 & ,000 & ,000 & ,000 & ,000 &, 000 & ,000 & ,000 & ,000 & ,000 & ,381 & ,000 \\
\hline SIDF2_1 & ,102 & ,336 &, 000 & ,000 & ,000 & ,000 & ,000 &, 000 & ,000 & ,000 & ,000 &, 555 & ,000 \\
\hline SVARS4_1 & 142 & ,469 &, 000 & ,000 & ,000 & ,000 &, 000 &, 000 & ,000 & ,000 & ,000 & ,000 &, 560 \\
\hline SVARS1_1 & 137 &, 452 &, 000 & ,000 & ,000 & ,000 &, 000 & ,000 & ,000 & ,000 & ,000 & ,000 & ,539 \\
\hline SVARF3_1 & ,187 & 618 & ,000 & ,000 & 000 & ,000 &, 000 &, 000 & ,000 & ,000 & ,000 & ,000 & ,737 \\
\hline AD_2008 & ,028 & ,301 &, 000 & ,000 & ,000 & ,000 &, 000 & ,000 & ,000 & ,000 & ,000 & ,000 & ,000 \\
\hline
\end{tabular}


Standardized Direct Effects (Global - Default model)

\begin{tabular}{|c|c|c|c|c|c|c|c|c|c|c|c|c|c|}
\hline & $I E$ & MOT & CEO & EMPT & $A C E$ & $A E$ & CEP & $A C P C$ & $A U T$ & $S I G$ & FED & $I D$ & $V A R$ \\
\hline$\overline{\mathrm{MOT}}$ &, 303 & ,000 & ,000 & ,000 &, 000 & ,000 & ,000 &, 000 & ,000 &, 000 &, 000 &, 000 &, 000 \\
\hline $\mathrm{CEO}$ & 911 & ,000 & ,000 & ,000 & ,000 & ,000 & ,000 & ,000 &, 000 & ,000 & ,000 & ,000 & ,000 \\
\hline EMP & 697 & ,000 & ,000 &, 000 & ,000 & ,000 & ,000 & ,000 & ,000 & ,000 & ,000 & ,000 & ,000 \\
\hline $\mathrm{ACE}$ &, 550 & ,000 & ,000 &, 000 & ,000 & ,000 & ,000 & ,000 & ,000 & ,000 & ,000 & ,000 & ,000 \\
\hline $\mathrm{AE}$ &, 750 & ,000 &, 000 & ,000 & ,000 & ,000 & 000 & ,000 & 000 & ,000 & ,000 & ,000 &, 000 \\
\hline CEP & ,786 & ,000 & ,000 & ,000 & ,000 & ,000 & ,000 & ,000 &, 000 & ,000 & ,000 & ,000 & ,000 \\
\hline $\mathrm{AC}$ & ,494 & ,000 & ,000 & ,000 & ,000 & ,000 & ,000 & ,000 & ,000 & ,000 & ,000 & ,000 & ,000 \\
\hline AUT & 000 & ,702 &, 000 & ,000 & ,000 & ,000 & 000 & ,000 & 000 & ,000 & ,000 & ,000 &, 000 \\
\hline SIG & ,000 & ,558 & ,000 &, 000 & ,000 & ,000 & ,000 & ,000 & ,000 & ,000 & ,000 & ,000 & ,000 \\
\hline FED & ,000 & ,666 & ,000 &, 000 & ,000 & ,000 & ,000 & ,000 &, 000 & ,000 & ,000 & ,000 & ,000 \\
\hline ID & 000 & 604, &, 000 & ,000 & ,000 & ,000 & 000 & ,000 & ,000 & ,000 & ,000 & ,000 &, 000 \\
\hline VAR & ,000 & ,838 & ,000 &, 000 & ,000 & ,000 & ,000 & ,000 & ,000 & ,000 & ,000 & ,000 & ,000 \\
\hline IE9_1 & ,000 & ,000 & ,000 & ,265 & ,000 & ,000 & ,000 & ,000 & ,000 & ,000 & ,000 & ,000 & ,000 \\
\hline IE21_1 & ,000 & ,000 & ,000 &, 000 & ,000 & ,000 & ,000 & ,871 & ,000 & ,000 & ,000 & ,000 & ,000 \\
\hline IE15_1 & ,000 & ,000 & ,000 & ,000 & ,000 & ,000 & ,000 & ,727 &, 000 & ,000 & ,000 & 000 & ,000 \\
\hline IE23_1 & ,000 & ,000 & ,000 &, 000 & ,000 & ,000 & ,613 & ,000 & ,000 & ,000 & ,000 & ,000 & ,000 \\
\hline IE20_1 & ,000 & ,000 & ,000 &, 000 & ,000 & ,000 & 651 & ,000 & ,000 & ,000 & ,000 & ,000 & ,000 \\
\hline IE11_1 & ,000 & ,000 & ,704 &, 000 & ,000 & ,000 & ,000 & ,000 & ,000 & ,000 & ,000 & ,000 & ,000 \\
\hline IE17_1 & ,000 & ,000 & ,787 & ,000 & ,000 & ,000 & ,000 & ,000 &, 000 & ,000 & ,000 & ,000 & ,000 \\
\hline IE18_1 & ,000 & ,000 & ,665 & ,000 & ,000 & ,000 & ,000 & ,000 & ,000 & ,000 & ,000 & ,000 & ,000 \\
\hline IE3_1 & ,000 & ,000 & ,000 & ,771 & ,000 & ,000 & ,000 & ,000 & ,000 & 000 & ,000 & 000 &, 000 \\
\hline IE5_1 & ,000 & ,000 & ,000 & ,327 & ,000 & ,000 & ,000 & ,000 & ,000 & ,000 & ,000 & ,000 & ,000 \\
\hline IE7_1 & ,000 & ,000 & ,000 & ,821 & ,000 & ,000 & ,000 & ,000 & ,000 & ,000 & ,000 & ,000 & ,000 \\
\hline IE4_1 & ,000 & ,000 & ,000 & ,000 & ,668 & ,000 & ,000 & ,000 & ,000 & ,000 & ,000 & ,000 & ,000 \\
\hline IE6_1 & ,000 & ,000 & ,000 & ,000 & 680 & ,000 & ,000 & ,000 &, 000 & 000 & ,000 & 000 &, 000 \\
\hline IE12_1 & ,000 & ,000 & ,000 &, 000 & 689 & ,000 & ,000 & ,000 & ,000 & ,000 & ,000 & ,000 & ,000 \\
\hline IE14_1 & ,000 & ,000 & ,000 &, 000 & ,000 & ,739 & ,000 & ,000 & ,000 & ,000 & ,000 & ,000 & ,000 \\
\hline IE19_1 & ,000 & ,000 & ,000 & ,000 & ,000 & ,769 & ,000 & ,000 &, 000 & ,000 & ,000 & ,000 & ,000 \\
\hline IE22_1 & ,000 & ,000 & ,000 &, 000 & ,000 & ,764 & ,000 & ,000 & ,000 & ,000 & ,000 & ,000 & ,000 \\
\hline IE16_1 & ,000 & ,000 & ,000 & ,000 & ,000 & ,000 & 841 & ,000 & ,000 & ,000 & ,000 & ,000 & ,000 \\
\hline IE10_1 & ,000 & ,000 & ,000 &, 000 & ,000 & ,000 & ,802 & ,000 & ,000 & ,000 & ,000 & ,000 & ,000 \\
\hline IE1_1 & ,000 & ,000 & ,000 &, 000 & ,000 & ,000 & ,652 & ,000 & ,000 & ,000 & ,000 & ,000 & ,000 \\
\hline IE2_1 & ,000 & ,000 & ,000 & ,000 & ,000 & ,000 & ,000 & ,621 &, 000 & ,000 & ,000 & ,000 & ,000 \\
\hline IE8_1 & ,000 & ,000 & ,000 & ,000 & ,000 & ,000 & ,000 & ,409 &, 000 & ,000 & ,000 & ,000 & ,000 \\
\hline IE13_1 & ,000 & ,000 & ,000 &, 000 & ,000 & ,000 & ,000 & ,482 & ,000 & ,000 & ,000 & ,000 & ,000 \\
\hline SAUTS9_1 & ,000 & ,000 & ,000 &, 000 & ,000 & ,000 & ,000 & ,000 & ,559 & ,000 & ,000 & ,000 & ,000 \\
\hline SAUTS6_1 & ,000 & ,000 & ,000 & ,000 & ,000 & ,000 & ,000 & ,000 & ,599, & ,000 & ,000 & ,000 & ,000 \\
\hline SAUTF1_1 & ,000 &, 000 & ,000 &, 000 & ,000 & ,000 & ,000 & ,000 &, 742 & ,000 & ,000 & ,000 &, 000 \\
\hline SSIGS5_1 & ,000 & ,000 & ,000 & ,000 & ,000 & 000 & ,000 & ,000 & ,000 & , 466 & 000 & 000 &, 000 \\
\hline SSIGF4_1 & ,000 & ,000 & ,000 &, 000 & ,000 & ,000 & ,000 & ,000 & ,000 & ,736 & ,000 & ,000 & ,000 \\
\hline SFEDS8_1 & ,000 &, 000 &, 000 &, 000 & ,000 & 000 & ,000 & 000 & 000 & 000 & , 452 & ,000 &, 000 \\
\hline SFEDS3_1 & ,000 & ,000 & ,000 &, 000 & ,000 & ,000 & ,000 & ,000 &, 000 & ,000 & ,391 & ,000 & ,000 \\
\hline SFEDF5_1 & ,000 & ,000 & ,000 & ,000 & ,000 & ,000 & ,000 & ,000 & ,000 & ,000 & ,713 & ,000 & ,000 \\
\hline SIDS7_1 & ,000 & ,000 & ,000 &, 000 & ,000 & ,000 & ,000 & ,000 & ,000 & ,000 & ,000 & ,381 & ,000 \\
\hline SIDF2_1 & ,000 & ,000 & ,000 &, 000 & ,000 & ,000 & ,000 & ,000 & ,000 & ,000 & ,000 & ,555 & ,000 \\
\hline SVARS4_1 & ,000 & ,000 & ,000 & ,000 & ,000 & ,000 & ,000 & ,000 & ,000 & ,000 & ,000 & 000 &, 560 \\
\hline SVARS1_1 & ,000 & ,000 & ,000 &, 000 & ,000 & ,000 & ,000 & ,000 & ,000 & ,000 & ,000 & ,000 & ,539 \\
\hline SVARF3_1 & ,000 & ,000 & ,000 &, 000 & ,000 & ,000 & ,000 & ,000 & ,000 & ,000 & ,000 & ,000 & ,737 \\
\hline AD_2008 &,- 063 & ,301 & ,000 & ,000 & ,000 & ,000 & ,000 & ,000 & ,000 & 000 & ,000 & 000 & ,000 \\
\hline
\end{tabular}


Standardized Indirect Effects (Global - Default model)

\begin{tabular}{|c|c|c|c|c|c|c|c|c|c|c|c|c|c|}
\hline & $I E$ & MOT & $\mathrm{CEO}$ & EMPT & $A C E$ & $A E$ & CEP & $A C P C$ & $A U T$ & $S I G$ & FED & $I D$ & $V A R$ \\
\hline MOT & ,000 & 000 & ,000 & ,000 & ,000 & ,000 & ,000 & ,000 & ,000 & ,000 & ,000 & ,000 &, 000 \\
\hline CEO & ,000 & 000 & ,000 & ,000 & ,000 & ,000 & ,000 & ,000 & ,000 & ,000 & 000 & ,000 & ,000 \\
\hline EMP & ,000 & ,000 & ,000 & ,000 & ,000 & ,000 & ,000 & ,000 & ,000 & ,000 & ,000 & ,000 & ,000 \\
\hline ACE & ,000 & 000 & 000 & ,000 & 000 & ,000 & 000 & 000 & ,000 & ,000 & ,000 & 000 & ,000 \\
\hline $\mathrm{AE}$ & ,000 & ,000 & ,000 & ,000 & ,000 & ,000 & ,000 & ,000 & ,000 & ,000 & ,000 & ,000 & ,000 \\
\hline CEP & ,000 & 000 & 000 & ,000 & 000 & ,000 & 000 & ,000 & ,000 & ,000 & ,000 & 000 & ,000 \\
\hline $\mathrm{AC}$ & ,000 & 000 & ,000 & ,000 & 000 & ,000 & 000 & 000 & ,000 & ,000 & 000 & 000 & ,000 \\
\hline AUT & ,212 & ,000 & 000 & ,000 & 000 & ,000 & 000 & 000 & ,000 & ,000 & 000 & 000 & ,000 \\
\hline SIG & ,169 & ,000 & ,000 & ,000 & ,000 & ,000 & ,000 & ,000 & ,000 & ,000 & ,000 & ,000 & ,000 \\
\hline FED & 202 & ,000 & 000 & ,000 & ,000 & 000 & 000 &, 000 & ,000 & ,000 & ,000 & 000 & ,000 \\
\hline ID & 183 & ,000 & ,000 & ,000 & ,000 & ,000 & ,000 & ,000 & ,000 & ,000 & ,000 & ,000 & ,000 \\
\hline VAR & ,254 & ,000 & ,000 & ,000 & ,000 & ,000 & ,000 & ,000 & ,000 & ,000 & ,000 & ,000 & ,000 \\
\hline IE9_1 & ,184 &, 000 & ,000 & ,000 & ,000 & ,000 & ,000 & 000 & ,000 & ,000 & ,000 & ,000 & ,000 \\
\hline IE21_1 & ,430 & ,000 & ,000 & ,000 & ,000 & ,000 & ,000 & ,000 & ,000 & ,000 & ,000 & ,000 & ,000 \\
\hline IE15_1 & ,359 &, 000 & ,000 & ,000 &, 000 & ,000 & ,000 & ,000 & ,000 & ,000 & ,000 & ,000 & ,000 \\
\hline IE23_1 & ,482 & ,000 & ,000 & ,000 & ,000 & ,000 & ,000 & ,000 & ,000 & ,000 & ,000 & ,000 & ,000 \\
\hline IE20_1 &, 511 & ,000 & ,000 & ,000 & ,000 & ,000 & ,000 & ,000 & ,000 & ,000 & ,000 & ,000 & ,000 \\
\hline IE11_1 & 641 & ,000 & ,000 & ,000 & ,000 & ,000 & ,000 & ,000 & ,000 & ,000 & ,000 & ,000 & ,000 \\
\hline IE17_1 & ,717 & ,000 & ,000 & ,000 & ,000 & ,000 & ,000 & ,000 & ,000 & ,000 & ,000 & ,000 & ,000 \\
\hline IE18_1 & ,606 & ,000 & ,000 & ,000 & ,000 & ,000 & ,000 & ,000 & ,000 & ,000 & ,000 & ,000 &, 000 \\
\hline IE3_1 & ,537 & ,000 &, 000 & ,000 & ,000 & ,000 & ,000 & ,000 & ,000 & ,000 & ,000 & ,000 & ,000 \\
\hline IE5_1 & ,228 & ,000 &, 000 & ,000 & ,000 & ,000 & ,000 &, 000 & ,000 & ,000 & ,000 & ,000 & ,000 \\
\hline IE7_1 & ,572 & ,000 &, 000 & ,000 & ,000 & ,000 & ,000 & ,000 & ,000 & ,000 & ,000 & ,000 & ,000 \\
\hline IE4_1 &, 367 & ,000 & ,000 & ,000 & ,000 & ,000 & ,000 & ,000 & ,000 & ,000 & ,000 & ,000 & ,000 \\
\hline IE6_1 & ,374 & ,000 & ,000 & ,000 & ,000 & ,000 &, 000 &, 000 & ,000 & ,000 & ,000 & ,000 & ,000 \\
\hline IE12_1 & ,379 & ,000 & ,000 & ,000 & ,000 & ,000 &, 000 & ,000 & ,000 & ,000 & ,000 & ,000 &, 000 \\
\hline & ,555 & ,000 &, 000 & ,000 & ,000 & ,000 &, 000 & ,000 & ,000 & ,000 & ,000 & ,000 & ,000 \\
\hline IE19_1 &, 577 & ,000 & ,000 & ,000 & ,000 & ,000 & ,000 &, 000 & ,000 & ,000 & ,000 & ,000 & ,000 \\
\hline IE22_1 & ,573 & ,000 & ,000 & ,000 & ,000 & ,000 & ,000 & ,000 & ,000 & ,000 & ,000 & ,000 & ,000 \\
\hline IE16_1 & ,660 & ,000 &, 000 & ,000 & ,000 & ,000 & ,000 & ,000 & ,000 & ,000 & ,000 & ,000 & ,000 \\
\hline IE10_1 & 630 & ,000 & ,000 & ,000 & ,000 & ,000 & ,000 & ,000 & ,000 & ,000 & ,000 & ,000 & ,000 \\
\hline IE1_1 & ,512 & ,000 &, 000 & ,000 & ,000 & ,000 & ,000 & ,000 & ,000 & ,000 & ,000 & ,000 & ,000 \\
\hline IE2_1 & ,307 & ,000 & ,000 & ,000 & ,000 & ,000 & ,000 &, 000 & ,000 & ,000 & ,000 & ,000 & ,000 \\
\hline IE8_1 & ,202 & ,000 &, 000 & ,000 & ,000 & ,000 &, 000 & ,000 & ,000 & ,000 & ,000 & ,000 & ,000 \\
\hline IE13_1 & ,238 & ,000 & ,000 & ,000 & ,000 & ,000 & ,000 & ,000 & ,000 & ,000 & ,000 & ,000 & ,000 \\
\hline SAUTS9_1 & ,119 & ,392 &, 000 & ,000 & ,000 & ,000 &, 000 & ,000 & ,000 & ,000 & ,000 & ,000 & ,000 \\
\hline SAUTS6_1 & ,127 & ,421 &, 000 & ,000 & ,000 & ,000 &, 000 & ,000 & ,000 & ,000 & ,000 & ,000 & ,000 \\
\hline SAUTF1_1 & ,158 &, 521 & ,000 & ,000 & ,000 & ,000 &, 000 &, 000 & ,000 & ,000 & ,000 & ,000 &, 000 \\
\hline SSIGS5_1 & ,079 & ,260 & ,000 & ,000 & ,000 & ,000 & ,000 & ,000 & ,000 & ,000 & ,000 & ,000 & ,000 \\
\hline SSIGF4_1 & ,124 & ,411 &, 000 & ,000 & ,000 &, 000 &, 000 &, 000 & ,000 & ,000 & ,000 &, 000 & ,000 \\
\hline SFEDS8_1 & ,091 & ,301 & ,000 & ,000 &, 000 & ,000 & ,000 & ,000 & ,000 & ,000 & ,000 & ,000 & ,000 \\
\hline SFEDS & ,079 & ,261 & ,000 & ,000 & ,000 &, 000 & ,000 & ,000 & ,000 & ,000 & ,000 & ,000 & ,000 \\
\hline SFEDF5_1 & 144 & ,475 & ,000 & ,000 & ,000 & ,000 &, 000 &, 000 & ,000 & ,000 & ,000 & ,000 & ,000 \\
\hline SIDS7_1 & ,070 & ,231 &, 000 & ,000 & ,000 & ,000 &, 000 & ,000 & ,000 & ,000 & ,000 &, 000 & ,000 \\
\hline SIDF2_1 & ,102 & ,336 & ,000 & ,000 & ,000 & ,000 & ,000 &, 000 & ,000 & ,000 & ,000 & ,000 & ,000 \\
\hline SVARS4_1 & ,142 & ,469 & ,000 & ,000 & ,000 & ,000 &, 000 & ,000 & ,000 & ,000 & ,000 & ,000 & ,000 \\
\hline SVARS1_1 & ,137 & ,452 &, 000 & ,000 & ,000 & ,000 &, 000 &, 000 & ,000 & ,000 & ,000 &, 000 & ,000 \\
\hline SVARF3_1 & ,187 & ,618 & ,000 & ,000 & ,000 & ,000 &, 000 &, 000 & ,000 & ,000 & ,000 &, 000 &, 000 \\
\hline AD_2008 & ,091 & ,000 &, 000 & ,000 & ,000 & ,000 & ,000 &, 000 & ,000 & ,000 & ,000 & ,000 & ,000 \\
\hline
\end{tabular}


Anexo $\mathrm{H}$

Estudos Exploratórios 
Diferenças entre Género:

\begin{tabular}{|c|c|c|c|c|c|}
\hline & Variable & Estimate & $\begin{array}{l}\text { Std. } \\
\text { Error }\end{array}$ & $\begin{array}{l}\text { Critical Ratio } \\
\text { for diferences }\end{array}$ & Hypotheses Test \\
\hline & Masculino & -0.231 & 0.164 & & $\begin{array}{l}\text { Valor encontra-se dentro do } \\
\text { intervalo de confiança }]-1.96 ; 1.96[\mathrm{e}\end{array}$ \\
\hline IE e AD & Feminino & -0.068 & 0.188 & -0.652 & $\begin{array}{l}\text { assim não se rejeita Ho, logo não } \\
\text { existem diferenças significativas entre } \\
\text { os géneros masculino e feminino }\end{array}$ \\
\hline $\begin{array}{c}\text { IE e } \\
\text { Motivação }\end{array}$ & Masculino & 0.407 & 0.168 & 1.431 & $\begin{array}{l}\text { Valor encontra-se dentro do } \\
\text { intervalo de confiança ]-1.96;1.96[ e } \\
\text { assim não se rejeita Ho, logo não } \\
\text { existem diferenças significativas entre } \\
\text { os géneros masculino e feminino }\end{array}$ \\
\hline
\end{tabular}

Teste bilateral $\operatorname{com} \alpha=0.05$

Diferenças entre Tipo de Função:

\begin{tabular}{|c|c|c|c|c|c|}
\hline & Variable & Estimate & $\begin{array}{l}\text { Std. } \\
\text { Error }\end{array}$ & $\begin{array}{l}\text { Critical Ratio } \\
\text { for diferences }\end{array}$ & Hypotheses Test \\
\hline & $\begin{array}{l}\text { Back- } \\
\text { Office }\end{array}$ & 0.404 & 0.286 & \multirow[b]{2}{*}{-0.662} & $\begin{array}{l}\text { Valor encontra-se dentro do intervalo } \\
\text { de confiança }]-1.96 ; 1.96[\text { e assim não }\end{array}$ \\
\hline $\begin{array}{c}\text { lE e } \\
\text { Motivação }\end{array}$ & $\begin{array}{l}\text { Front- } \\
\text { Office }\end{array}$ & 0.614 & 0.135 & & $\begin{array}{l}\text { se rejeita Ho, logo não existem } \\
\text { diferenças significativas entre os } \\
\text { géneros masculino e feminino }\end{array}$ \\
\hline \multirow{2}{*}{$\begin{array}{l}\text { Motivação } \\
\text { e AD }\end{array}$} & $\begin{array}{l}\text { Back- } \\
\text { Office }\end{array}$ & 0.625 & 0.152 & \multirow[b]{2}{*}{1.403} & $\begin{array}{l}\text { Valor encontra-se dentro do intervalo } \\
\text { de confiança }]-1.96 ; 1.96[\text { e assim não }\end{array}$ \\
\hline & $\begin{array}{l}\text { Front- } \\
\text { Office }\end{array}$ & 0.363 & 0.108 & & $\begin{array}{l}\text { se rejeita Ho, logo não existem } \\
\text { diferenças significativas entre os } \\
\text { géneros masculino e feminino }\end{array}$ \\
\hline
\end{tabular}

Teste bilateral $\operatorname{com} \alpha=0.05$ 
Diferenças entre Habilitações Académicas:

\begin{tabular}{|c|c|c|c|c|c|}
\hline & Variable & Estimate & $\begin{array}{l}\text { Std. } \\
\text { Error }\end{array}$ & $\begin{array}{l}\text { Critical Ratio } \\
\text { for diferences }\end{array}$ & Hypotheses Test \\
\hline & $\begin{array}{c}\text { Até } \\
\text { Secundário }\end{array}$ & 0.566 & 0.217 & \multirow[b]{2}{*}{0.06} & $\begin{array}{l}\text { Valor encontra-se dentro do } \\
\text { intervalo de confiança ]-1.96;1.96[ e }\end{array}$ \\
\hline $\begin{array}{c}\text { IE e } \\
\text { Motivação }\end{array}$ & $\begin{array}{l}\text { Ensino } \\
\text { Superior }\end{array}$ & 0.582 & 0.14 & & $\begin{array}{c}\text { assim não se rejeita Ho, logo não } \\
\text { existem diferenças significativas } \\
\text { entre os géneros masculino e } \\
\text { feminino }\end{array}$ \\
\hline \multirow[b]{2}{*}{$\begin{array}{l}\text { Motivação } \\
\text { e AD }\end{array}$} & $\begin{array}{l}\text { Até } \\
\text { Secundário }\end{array}$ & 0.633 & 0.198 & \multirow[b]{2}{*}{-1.045} & $\begin{array}{l}\text { Valor encontra-se dentro do } \\
\text { intervalo de confiança ]-1.96;1.96[e }\end{array}$ \\
\hline & $\begin{array}{l}\text { Ensino } \\
\text { Superior }\end{array}$ & 0.404 & 0.094 & & $\begin{array}{c}\text { assim não se rejeita Ho, logo não } \\
\text { existem diferenças significativas } \\
\text { entre os géneros masculino e } \\
\text { feminino }\end{array}$ \\
\hline
\end{tabular}

Teste bilateral $\operatorname{com} \alpha=0.05$ 
Diferenças entre Habilitações Académicas:

\begin{tabular}{|c|c|c|c|c|c|}
\hline & Variable & Estimate & $\begin{array}{l}\text { Std. } \\
\text { Error }\end{array}$ & $\begin{array}{l}\text { Critical Ratio } \\
\text { for diferences }\end{array}$ & Hypotheses Test \\
\hline & $\begin{array}{c}\text { Até } \\
\text { Secundário }\end{array}$ & 0.566 & 0.217 & \multirow[b]{2}{*}{0.06} & $\begin{array}{l}\text { Valor encontra-se dentro do } \\
\text { intervalo de confiança ]-1.96;1.96[ e }\end{array}$ \\
\hline $\begin{array}{c}\text { IE e } \\
\text { Motivação }\end{array}$ & $\begin{array}{l}\text { Ensino } \\
\text { Superior }\end{array}$ & 0.582 & 0.14 & & $\begin{array}{c}\text { assim não se rejeita Ho, logo não } \\
\text { existem diferenças significativas } \\
\text { entre os géneros masculino e } \\
\text { feminino }\end{array}$ \\
\hline \multirow[b]{2}{*}{$\begin{array}{l}\text { Motivação } \\
\text { e AD }\end{array}$} & $\begin{array}{l}\text { Até } \\
\text { Secundário }\end{array}$ & 0.633 & 0.198 & \multirow[b]{2}{*}{-1.045} & $\begin{array}{l}\text { Valor encontra-se dentro do } \\
\text { intervalo de confiança ]-1.96;1.96[e }\end{array}$ \\
\hline & $\begin{array}{l}\text { Ensino } \\
\text { Superior }\end{array}$ & 0.404 & 0.094 & & $\begin{array}{c}\text { assim não se rejeita Ho, logo não } \\
\text { existem diferenças significativas } \\
\text { entre os géneros masculino e } \\
\text { feminino }\end{array}$ \\
\hline
\end{tabular}

Teste bilateral $\operatorname{com} \alpha=0.05$ 
Diferenças entre Habilitações Académicas:

\begin{tabular}{|c|c|c|c|c|c|}
\hline & Variable & Estimate & $\begin{array}{l}\text { Std. } \\
\text { Error }\end{array}$ & $\begin{array}{l}\text { Critical Ratio } \\
\text { for diferences }\end{array}$ & Hypotheses Test \\
\hline & $\begin{array}{c}\text { Até } \\
\text { Secundário }\end{array}$ & 0.566 & 0.217 & \multirow[b]{2}{*}{0.06} & $\begin{array}{l}\text { Valor encontra-se dentro do } \\
\text { intervalo de confiança ]-1.96;1.96[ e }\end{array}$ \\
\hline $\begin{array}{c}\text { IE e } \\
\text { Motivação }\end{array}$ & $\begin{array}{l}\text { Ensino } \\
\text { Superior }\end{array}$ & 0.582 & 0.14 & & $\begin{array}{c}\text { assim não se rejeita Ho, logo não } \\
\text { existem diferenças significativas } \\
\text { entre os géneros masculino e } \\
\text { feminino }\end{array}$ \\
\hline \multirow[b]{2}{*}{$\begin{array}{l}\text { Motivação } \\
\text { e AD }\end{array}$} & $\begin{array}{l}\text { Até } \\
\text { Secundário }\end{array}$ & 0.633 & 0.198 & \multirow[b]{2}{*}{-1.045} & $\begin{array}{l}\text { Valor encontra-se dentro do } \\
\text { intervalo de confiança ]-1.96;1.96[e }\end{array}$ \\
\hline & $\begin{array}{l}\text { Ensino } \\
\text { Superior }\end{array}$ & 0.404 & 0.094 & & $\begin{array}{c}\text { assim não se rejeita Ho, logo não } \\
\text { existem diferenças significativas } \\
\text { entre os géneros masculino e } \\
\text { feminino }\end{array}$ \\
\hline
\end{tabular}

Teste bilateral $\operatorname{com} \alpha=0.05$ 
Diferenças entre Habilitações Académicas:

\begin{tabular}{|c|c|c|c|c|c|}
\hline & Variable & Estimate & $\begin{array}{l}\text { Std. } \\
\text { Error }\end{array}$ & $\begin{array}{l}\text { Critical Ratio } \\
\text { for diferences }\end{array}$ & Hypotheses Test \\
\hline & $\begin{array}{c}\text { Até } \\
\text { Secundário }\end{array}$ & 0.566 & 0.217 & \multirow[b]{2}{*}{0.06} & $\begin{array}{l}\text { Valor encontra-se dentro do } \\
\text { intervalo de confiança ]-1.96;1.96[ e }\end{array}$ \\
\hline $\begin{array}{c}\text { IE e } \\
\text { Motivação }\end{array}$ & $\begin{array}{l}\text { Ensino } \\
\text { Superior }\end{array}$ & 0.582 & 0.14 & & $\begin{array}{c}\text { assim não se rejeita Ho, logo não } \\
\text { existem diferenças significativas } \\
\text { entre os géneros masculino e } \\
\text { feminino }\end{array}$ \\
\hline \multirow[b]{2}{*}{$\begin{array}{l}\text { Motivação } \\
\text { e AD }\end{array}$} & $\begin{array}{l}\text { Até } \\
\text { Secundário }\end{array}$ & 0.633 & 0.198 & \multirow[b]{2}{*}{-1.045} & $\begin{array}{l}\text { Valor encontra-se dentro do } \\
\text { intervalo de confiança ]-1.96;1.96[e }\end{array}$ \\
\hline & $\begin{array}{l}\text { Ensino } \\
\text { Superior }\end{array}$ & 0.404 & 0.094 & & $\begin{array}{c}\text { assim não se rejeita Ho, logo não } \\
\text { existem diferenças significativas } \\
\text { entre os géneros masculino e } \\
\text { feminino }\end{array}$ \\
\hline
\end{tabular}

Teste bilateral $\operatorname{com} \alpha=0.05$ 
Diferenças entre Habilitações Académicas:

\begin{tabular}{|c|c|c|c|c|c|}
\hline & Variable & Estimate & $\begin{array}{l}\text { Std. } \\
\text { Error }\end{array}$ & $\begin{array}{l}\text { Critical Ratio } \\
\text { for diferences }\end{array}$ & Hypotheses Test \\
\hline & $\begin{array}{c}\text { Até } \\
\text { Secundário }\end{array}$ & 0.566 & 0.217 & \multirow[b]{2}{*}{0.06} & $\begin{array}{l}\text { Valor encontra-se dentro do } \\
\text { intervalo de confiança ]-1.96;1.96[ e }\end{array}$ \\
\hline $\begin{array}{c}\text { IE e } \\
\text { Motivação }\end{array}$ & $\begin{array}{l}\text { Ensino } \\
\text { Superior }\end{array}$ & 0.582 & 0.14 & & $\begin{array}{c}\text { assim não se rejeita Ho, logo não } \\
\text { existem diferenças significativas } \\
\text { entre os géneros masculino e } \\
\text { feminino }\end{array}$ \\
\hline \multirow[b]{2}{*}{$\begin{array}{l}\text { Motivação } \\
\text { e AD }\end{array}$} & $\begin{array}{l}\text { Até } \\
\text { Secundário }\end{array}$ & 0.633 & 0.198 & \multirow[b]{2}{*}{-1.045} & $\begin{array}{l}\text { Valor encontra-se dentro do } \\
\text { intervalo de confiança ]-1.96;1.96[e }\end{array}$ \\
\hline & $\begin{array}{l}\text { Ensino } \\
\text { Superior }\end{array}$ & 0.404 & 0.094 & & $\begin{array}{c}\text { assim não se rejeita Ho, logo não } \\
\text { existem diferenças significativas } \\
\text { entre os géneros masculino e } \\
\text { feminino }\end{array}$ \\
\hline
\end{tabular}

Teste bilateral $\operatorname{com} \alpha=0.05$ 
Diferenças entre Habilitações Académicas:

\begin{tabular}{|c|c|c|c|c|c|}
\hline & Variable & Estimate & $\begin{array}{l}\text { Std. } \\
\text { Error }\end{array}$ & $\begin{array}{l}\text { Critical Ratio } \\
\text { for diferences }\end{array}$ & Hypotheses Test \\
\hline & $\begin{array}{c}\text { Até } \\
\text { Secundário }\end{array}$ & 0.566 & 0.217 & \multirow[b]{2}{*}{0.06} & $\begin{array}{l}\text { Valor encontra-se dentro do } \\
\text { intervalo de confiança ]-1.96;1.96[ e }\end{array}$ \\
\hline $\begin{array}{c}\text { IE e } \\
\text { Motivação }\end{array}$ & $\begin{array}{l}\text { Ensino } \\
\text { Superior }\end{array}$ & 0.582 & 0.14 & & $\begin{array}{c}\text { assim não se rejeita Ho, logo não } \\
\text { existem diferenças significativas } \\
\text { entre os géneros masculino e } \\
\text { feminino }\end{array}$ \\
\hline \multirow[b]{2}{*}{$\begin{array}{l}\text { Motivação } \\
\text { e AD }\end{array}$} & $\begin{array}{l}\text { Até } \\
\text { Secundário }\end{array}$ & 0.633 & 0.198 & \multirow[b]{2}{*}{-1.045} & $\begin{array}{l}\text { Valor encontra-se dentro do } \\
\text { intervalo de confiança ]-1.96;1.96[e }\end{array}$ \\
\hline & $\begin{array}{l}\text { Ensino } \\
\text { Superior }\end{array}$ & 0.404 & 0.094 & & $\begin{array}{c}\text { assim não se rejeita Ho, logo não } \\
\text { existem diferenças significativas } \\
\text { entre os géneros masculino e } \\
\text { feminino }\end{array}$ \\
\hline
\end{tabular}

Teste bilateral $\operatorname{com} \alpha=0.05$ 
Diferenças entre Habilitações Académicas:

\begin{tabular}{|c|c|c|c|c|c|}
\hline & Variable & Estimate & $\begin{array}{l}\text { Std. } \\
\text { Error }\end{array}$ & $\begin{array}{l}\text { Critical Ratio } \\
\text { for diferences }\end{array}$ & Hypotheses Test \\
\hline & $\begin{array}{c}\text { Até } \\
\text { Secundário }\end{array}$ & 0.566 & 0.217 & \multirow[b]{2}{*}{0.06} & $\begin{array}{l}\text { Valor encontra-se dentro do } \\
\text { intervalo de confiança ]-1.96;1.96[ e }\end{array}$ \\
\hline $\begin{array}{c}\text { IE e } \\
\text { Motivação }\end{array}$ & $\begin{array}{l}\text { Ensino } \\
\text { Superior }\end{array}$ & 0.582 & 0.14 & & $\begin{array}{c}\text { assim não se rejeita Ho, logo não } \\
\text { existem diferenças significativas } \\
\text { entre os géneros masculino e } \\
\text { feminino }\end{array}$ \\
\hline \multirow[b]{2}{*}{$\begin{array}{l}\text { Motivação } \\
\text { e AD }\end{array}$} & $\begin{array}{l}\text { Até } \\
\text { Secundário }\end{array}$ & 0.633 & 0.198 & \multirow[b]{2}{*}{-1.045} & $\begin{array}{l}\text { Valor encontra-se dentro do } \\
\text { intervalo de confiança ]-1.96;1.96[e }\end{array}$ \\
\hline & $\begin{array}{l}\text { Ensino } \\
\text { Superior }\end{array}$ & 0.404 & 0.094 & & $\begin{array}{c}\text { assim não se rejeita Ho, logo não } \\
\text { existem diferenças significativas } \\
\text { entre os géneros masculino e } \\
\text { feminino }\end{array}$ \\
\hline
\end{tabular}

Teste bilateral $\operatorname{com} \alpha=0.05$ 
Diferenças entre Habilitações Académicas:

\begin{tabular}{|c|c|c|c|c|c|}
\hline & Variable & Estimate & $\begin{array}{l}\text { Std. } \\
\text { Error }\end{array}$ & $\begin{array}{l}\text { Critical Ratio } \\
\text { for diferences }\end{array}$ & Hypotheses Test \\
\hline & $\begin{array}{c}\text { Até } \\
\text { Secundário }\end{array}$ & 0.566 & 0.217 & \multirow[b]{2}{*}{0.06} & $\begin{array}{l}\text { Valor encontra-se dentro do } \\
\text { intervalo de confiança ]-1.96;1.96[ e }\end{array}$ \\
\hline $\begin{array}{c}\text { IE e } \\
\text { Motivação }\end{array}$ & $\begin{array}{l}\text { Ensino } \\
\text { Superior }\end{array}$ & 0.582 & 0.14 & & $\begin{array}{c}\text { assim não se rejeita Ho, logo não } \\
\text { existem diferenças significativas } \\
\text { entre os géneros masculino e } \\
\text { feminino }\end{array}$ \\
\hline \multirow[b]{2}{*}{$\begin{array}{l}\text { Motivação } \\
\text { e AD }\end{array}$} & $\begin{array}{l}\text { Até } \\
\text { Secundário }\end{array}$ & 0.633 & 0.198 & \multirow[b]{2}{*}{-1.045} & $\begin{array}{l}\text { Valor encontra-se dentro do } \\
\text { intervalo de confiança ]-1.96;1.96[e }\end{array}$ \\
\hline & $\begin{array}{l}\text { Ensino } \\
\text { Superior }\end{array}$ & 0.404 & 0.094 & & $\begin{array}{c}\text { assim não se rejeita Ho, logo não } \\
\text { existem diferenças significativas } \\
\text { entre os géneros masculino e } \\
\text { feminino }\end{array}$ \\
\hline
\end{tabular}

Teste bilateral $\operatorname{com} \alpha=0.05$ 
Diferenças entre Habilitações Académicas:

\begin{tabular}{|c|c|c|c|c|c|}
\hline & Variable & Estimate & $\begin{array}{l}\text { Std. } \\
\text { Error }\end{array}$ & $\begin{array}{l}\text { Critical Ratio } \\
\text { for diferences }\end{array}$ & Hypotheses Test \\
\hline & $\begin{array}{c}\text { Até } \\
\text { Secundário }\end{array}$ & 0.566 & 0.217 & \multirow[b]{2}{*}{0.06} & $\begin{array}{l}\text { Valor encontra-se dentro do } \\
\text { intervalo de confiança ]-1.96;1.96[ e }\end{array}$ \\
\hline $\begin{array}{c}\text { IE e } \\
\text { Motivação }\end{array}$ & $\begin{array}{l}\text { Ensino } \\
\text { Superior }\end{array}$ & 0.582 & 0.14 & & $\begin{array}{c}\text { assim não se rejeita Ho, logo não } \\
\text { existem diferenças significativas } \\
\text { entre os géneros masculino e } \\
\text { feminino }\end{array}$ \\
\hline \multirow[b]{2}{*}{$\begin{array}{l}\text { Motivação } \\
\text { e AD }\end{array}$} & $\begin{array}{l}\text { Até } \\
\text { Secundário }\end{array}$ & 0.633 & 0.198 & \multirow[b]{2}{*}{-1.045} & $\begin{array}{l}\text { Valor encontra-se dentro do } \\
\text { intervalo de confiança ]-1.96;1.96[e }\end{array}$ \\
\hline & $\begin{array}{l}\text { Ensino } \\
\text { Superior }\end{array}$ & 0.404 & 0.094 & & $\begin{array}{c}\text { assim não se rejeita Ho, logo não } \\
\text { existem diferenças significativas } \\
\text { entre os géneros masculino e } \\
\text { feminino }\end{array}$ \\
\hline
\end{tabular}

Teste bilateral $\operatorname{com} \alpha=0.05$ 
Diferenças entre Habilitações Académicas:

\begin{tabular}{|c|c|c|c|c|c|}
\hline & Variable & Estimate & $\begin{array}{l}\text { Std. } \\
\text { Error }\end{array}$ & $\begin{array}{l}\text { Critical Ratio } \\
\text { for diferences }\end{array}$ & Hypotheses Test \\
\hline & $\begin{array}{c}\text { Até } \\
\text { Secundário }\end{array}$ & 0.566 & 0.217 & \multirow[b]{2}{*}{0.06} & $\begin{array}{l}\text { Valor encontra-se dentro do } \\
\text { intervalo de confiança ]-1.96;1.96[ e }\end{array}$ \\
\hline $\begin{array}{c}\text { IE e } \\
\text { Motivação }\end{array}$ & $\begin{array}{l}\text { Ensino } \\
\text { Superior }\end{array}$ & 0.582 & 0.14 & & $\begin{array}{c}\text { assim não se rejeita Ho, logo não } \\
\text { existem diferenças significativas } \\
\text { entre os géneros masculino e } \\
\text { feminino }\end{array}$ \\
\hline \multirow[b]{2}{*}{$\begin{array}{l}\text { Motivação } \\
\text { e AD }\end{array}$} & $\begin{array}{l}\text { Até } \\
\text { Secundário }\end{array}$ & 0.633 & 0.198 & \multirow[b]{2}{*}{-1.045} & $\begin{array}{l}\text { Valor encontra-se dentro do } \\
\text { intervalo de confiança ]-1.96;1.96[e }\end{array}$ \\
\hline & $\begin{array}{l}\text { Ensino } \\
\text { Superior }\end{array}$ & 0.404 & 0.094 & & $\begin{array}{c}\text { assim não se rejeita Ho, logo não } \\
\text { existem diferenças significativas } \\
\text { entre os géneros masculino e } \\
\text { feminino }\end{array}$ \\
\hline
\end{tabular}

Teste bilateral $\operatorname{com} \alpha=0.05$ 
Diferenças entre Habilitações Académicas:

\begin{tabular}{|c|c|c|c|c|c|}
\hline & Variable & Estimate & $\begin{array}{l}\text { Std. } \\
\text { Error }\end{array}$ & $\begin{array}{l}\text { Critical Ratio } \\
\text { for diferences }\end{array}$ & Hypotheses Test \\
\hline & $\begin{array}{c}\text { Até } \\
\text { Secundário }\end{array}$ & 0.566 & 0.217 & \multirow[b]{2}{*}{0.06} & $\begin{array}{l}\text { Valor encontra-se dentro do } \\
\text { intervalo de confiança ]-1.96;1.96[ e }\end{array}$ \\
\hline $\begin{array}{c}\text { IE e } \\
\text { Motivação }\end{array}$ & $\begin{array}{l}\text { Ensino } \\
\text { Superior }\end{array}$ & 0.582 & 0.14 & & $\begin{array}{c}\text { assim não se rejeita Ho, logo não } \\
\text { existem diferenças significativas } \\
\text { entre os géneros masculino e } \\
\text { feminino }\end{array}$ \\
\hline \multirow[b]{2}{*}{$\begin{array}{l}\text { Motivação } \\
\text { e AD }\end{array}$} & $\begin{array}{l}\text { Até } \\
\text { Secundário }\end{array}$ & 0.633 & 0.198 & \multirow[b]{2}{*}{-1.045} & $\begin{array}{l}\text { Valor encontra-se dentro do } \\
\text { intervalo de confiança ]-1.96;1.96[e }\end{array}$ \\
\hline & $\begin{array}{l}\text { Ensino } \\
\text { Superior }\end{array}$ & 0.404 & 0.094 & & $\begin{array}{c}\text { assim não se rejeita Ho, logo não } \\
\text { existem diferenças significativas } \\
\text { entre os géneros masculino e } \\
\text { feminino }\end{array}$ \\
\hline
\end{tabular}

Teste bilateral $\operatorname{com} \alpha=0.05$ 
Diferenças entre Habilitações Académicas:

\begin{tabular}{|c|c|c|c|c|c|}
\hline & Variable & Estimate & $\begin{array}{l}\text { Std. } \\
\text { Error }\end{array}$ & $\begin{array}{l}\text { Critical Ratio } \\
\text { for diferences }\end{array}$ & Hypotheses Test \\
\hline & $\begin{array}{c}\text { Até } \\
\text { Secundário }\end{array}$ & 0.566 & 0.217 & \multirow[b]{2}{*}{0.06} & $\begin{array}{l}\text { Valor encontra-se dentro do } \\
\text { intervalo de confiança ]-1.96;1.96[ e }\end{array}$ \\
\hline $\begin{array}{c}\text { IE e } \\
\text { Motivação }\end{array}$ & $\begin{array}{l}\text { Ensino } \\
\text { Superior }\end{array}$ & 0.582 & 0.14 & & $\begin{array}{c}\text { assim não se rejeita Ho, logo não } \\
\text { existem diferenças significativas } \\
\text { entre os géneros masculino e } \\
\text { feminino }\end{array}$ \\
\hline \multirow[b]{2}{*}{$\begin{array}{l}\text { Motivação } \\
\text { e AD }\end{array}$} & $\begin{array}{l}\text { Até } \\
\text { Secundário }\end{array}$ & 0.633 & 0.198 & \multirow[b]{2}{*}{-1.045} & $\begin{array}{l}\text { Valor encontra-se dentro do } \\
\text { intervalo de confiança ]-1.96;1.96[e }\end{array}$ \\
\hline & $\begin{array}{l}\text { Ensino } \\
\text { Superior }\end{array}$ & 0.404 & 0.094 & & $\begin{array}{c}\text { assim não se rejeita Ho, logo não } \\
\text { existem diferenças significativas } \\
\text { entre os géneros masculino e } \\
\text { feminino }\end{array}$ \\
\hline
\end{tabular}

Teste bilateral $\operatorname{com} \alpha=0.05$ 
Diferenças entre Habilitações Académicas:

\begin{tabular}{|c|c|c|c|c|c|}
\hline & Variable & Estimate & $\begin{array}{l}\text { Std. } \\
\text { Error }\end{array}$ & $\begin{array}{l}\text { Critical Ratio } \\
\text { for diferences }\end{array}$ & Hypotheses Test \\
\hline & $\begin{array}{c}\text { Até } \\
\text { Secundário }\end{array}$ & 0.566 & 0.217 & \multirow[b]{2}{*}{0.06} & $\begin{array}{l}\text { Valor encontra-se dentro do } \\
\text { intervalo de confiança ]-1.96;1.96[ e }\end{array}$ \\
\hline $\begin{array}{c}\text { IE e } \\
\text { Motivação }\end{array}$ & $\begin{array}{l}\text { Ensino } \\
\text { Superior }\end{array}$ & 0.582 & 0.14 & & $\begin{array}{c}\text { assim não se rejeita Ho, logo não } \\
\text { existem diferenças significativas } \\
\text { entre os géneros masculino e } \\
\text { feminino }\end{array}$ \\
\hline \multirow[b]{2}{*}{$\begin{array}{l}\text { Motivação } \\
\text { e AD }\end{array}$} & $\begin{array}{l}\text { Até } \\
\text { Secundário }\end{array}$ & 0.633 & 0.198 & \multirow[b]{2}{*}{-1.045} & $\begin{array}{l}\text { Valor encontra-se dentro do } \\
\text { intervalo de confiança ]-1.96;1.96[e }\end{array}$ \\
\hline & $\begin{array}{l}\text { Ensino } \\
\text { Superior }\end{array}$ & 0.404 & 0.094 & & $\begin{array}{c}\text { assim não se rejeita Ho, logo não } \\
\text { existem diferenças significativas } \\
\text { entre os géneros masculino e } \\
\text { feminino }\end{array}$ \\
\hline
\end{tabular}

Teste bilateral $\operatorname{com} \alpha=0.05$ 
Diferenças entre Habilitações Académicas:

\begin{tabular}{|c|c|c|c|c|c|}
\hline & Variable & Estimate & $\begin{array}{l}\text { Std. } \\
\text { Error }\end{array}$ & $\begin{array}{l}\text { Critical Ratio } \\
\text { for diferences }\end{array}$ & Hypotheses Test \\
\hline & $\begin{array}{c}\text { Até } \\
\text { Secundário }\end{array}$ & 0.566 & 0.217 & \multirow[b]{2}{*}{0.06} & $\begin{array}{l}\text { Valor encontra-se dentro do } \\
\text { intervalo de confiança ]-1.96;1.96[ e }\end{array}$ \\
\hline $\begin{array}{c}\text { IE e } \\
\text { Motivação }\end{array}$ & $\begin{array}{l}\text { Ensino } \\
\text { Superior }\end{array}$ & 0.582 & 0.14 & & $\begin{array}{c}\text { assim não se rejeita Ho, logo não } \\
\text { existem diferenças significativas } \\
\text { entre os géneros masculino e } \\
\text { feminino }\end{array}$ \\
\hline \multirow[b]{2}{*}{$\begin{array}{l}\text { Motivação } \\
\text { e AD }\end{array}$} & $\begin{array}{l}\text { Até } \\
\text { Secundário }\end{array}$ & 0.633 & 0.198 & \multirow[b]{2}{*}{-1.045} & $\begin{array}{l}\text { Valor encontra-se dentro do } \\
\text { intervalo de confiança ]-1.96;1.96[e }\end{array}$ \\
\hline & $\begin{array}{l}\text { Ensino } \\
\text { Superior }\end{array}$ & 0.404 & 0.094 & & $\begin{array}{c}\text { assim não se rejeita Ho, logo não } \\
\text { existem diferenças significativas } \\
\text { entre os géneros masculino e } \\
\text { feminino }\end{array}$ \\
\hline
\end{tabular}

Teste bilateral $\operatorname{com} \alpha=0.05$ 
Diferenças entre Habilitações Académicas:

\begin{tabular}{|c|c|c|c|c|c|}
\hline & Variable & Estimate & $\begin{array}{l}\text { Std. } \\
\text { Error }\end{array}$ & $\begin{array}{l}\text { Critical Ratio } \\
\text { for diferences }\end{array}$ & Hypotheses Test \\
\hline & $\begin{array}{c}\text { Até } \\
\text { Secundário }\end{array}$ & 0.566 & 0.217 & \multirow[b]{2}{*}{0.06} & $\begin{array}{l}\text { Valor encontra-se dentro do } \\
\text { intervalo de confiança ]-1.96;1.96[ e }\end{array}$ \\
\hline $\begin{array}{c}\text { IE e } \\
\text { Motivação }\end{array}$ & $\begin{array}{l}\text { Ensino } \\
\text { Superior }\end{array}$ & 0.582 & 0.14 & & $\begin{array}{c}\text { assim não se rejeita Ho, logo não } \\
\text { existem diferenças significativas } \\
\text { entre os géneros masculino e } \\
\text { feminino }\end{array}$ \\
\hline \multirow[b]{2}{*}{$\begin{array}{l}\text { Motivação } \\
\text { e AD }\end{array}$} & $\begin{array}{l}\text { Até } \\
\text { Secundário }\end{array}$ & 0.633 & 0.198 & \multirow[b]{2}{*}{-1.045} & $\begin{array}{l}\text { Valor encontra-se dentro do } \\
\text { intervalo de confiança ]-1.96;1.96[e }\end{array}$ \\
\hline & $\begin{array}{l}\text { Ensino } \\
\text { Superior }\end{array}$ & 0.404 & 0.094 & & $\begin{array}{c}\text { assim não se rejeita Ho, logo não } \\
\text { existem diferenças significativas } \\
\text { entre os géneros masculino e } \\
\text { feminino }\end{array}$ \\
\hline
\end{tabular}

Teste bilateral $\operatorname{com} \alpha=0.05$ 
Diferenças entre Habilitações Académicas:

\begin{tabular}{|c|c|c|c|c|c|}
\hline & Variable & Estimate & $\begin{array}{l}\text { Std. } \\
\text { Error }\end{array}$ & $\begin{array}{l}\text { Critical Ratio } \\
\text { for diferences }\end{array}$ & Hypotheses Test \\
\hline & $\begin{array}{c}\text { Até } \\
\text { Secundário }\end{array}$ & 0.566 & 0.217 & \multirow[b]{2}{*}{0.06} & $\begin{array}{l}\text { Valor encontra-se dentro do } \\
\text { intervalo de confiança ]-1.96;1.96[ e }\end{array}$ \\
\hline $\begin{array}{c}\text { IE e } \\
\text { Motivação }\end{array}$ & $\begin{array}{l}\text { Ensino } \\
\text { Superior }\end{array}$ & 0.582 & 0.14 & & $\begin{array}{c}\text { assim não se rejeita Ho, logo não } \\
\text { existem diferenças significativas } \\
\text { entre os géneros masculino e } \\
\text { feminino }\end{array}$ \\
\hline \multirow[b]{2}{*}{$\begin{array}{l}\text { Motivação } \\
\text { e AD }\end{array}$} & $\begin{array}{l}\text { Até } \\
\text { Secundário }\end{array}$ & 0.633 & 0.198 & \multirow[b]{2}{*}{-1.045} & $\begin{array}{l}\text { Valor encontra-se dentro do } \\
\text { intervalo de confiança ]-1.96;1.96[e }\end{array}$ \\
\hline & $\begin{array}{l}\text { Ensino } \\
\text { Superior }\end{array}$ & 0.404 & 0.094 & & $\begin{array}{c}\text { assim não se rejeita Ho, logo não } \\
\text { existem diferenças significativas } \\
\text { entre os géneros masculino e } \\
\text { feminino }\end{array}$ \\
\hline
\end{tabular}

Teste bilateral $\operatorname{com} \alpha=0.05$ 
Diferenças entre Habilitações Académicas:

\begin{tabular}{|c|c|c|c|c|c|}
\hline & Variable & Estimate & $\begin{array}{l}\text { Std. } \\
\text { Error }\end{array}$ & $\begin{array}{l}\text { Critical Ratio } \\
\text { for diferences }\end{array}$ & Hypotheses Test \\
\hline & $\begin{array}{c}\text { Até } \\
\text { Secundário }\end{array}$ & 0.566 & 0.217 & \multirow[b]{2}{*}{0.06} & $\begin{array}{l}\text { Valor encontra-se dentro do } \\
\text { intervalo de confiança ]-1.96;1.96[ e }\end{array}$ \\
\hline $\begin{array}{c}\text { IE e } \\
\text { Motivação }\end{array}$ & $\begin{array}{l}\text { Ensino } \\
\text { Superior }\end{array}$ & 0.582 & 0.14 & & $\begin{array}{c}\text { assim não se rejeita Ho, logo não } \\
\text { existem diferenças significativas } \\
\text { entre os géneros masculino e } \\
\text { feminino }\end{array}$ \\
\hline \multirow[b]{2}{*}{$\begin{array}{l}\text { Motivação } \\
\text { e AD }\end{array}$} & $\begin{array}{l}\text { Até } \\
\text { Secundário }\end{array}$ & 0.633 & 0.198 & \multirow[b]{2}{*}{-1.045} & $\begin{array}{l}\text { Valor encontra-se dentro do } \\
\text { intervalo de confiança ]-1.96;1.96[e }\end{array}$ \\
\hline & $\begin{array}{l}\text { Ensino } \\
\text { Superior }\end{array}$ & 0.404 & 0.094 & & $\begin{array}{c}\text { assim não se rejeita Ho, logo não } \\
\text { existem diferenças significativas } \\
\text { entre os géneros masculino e } \\
\text { feminino }\end{array}$ \\
\hline
\end{tabular}

Teste bilateral $\operatorname{com} \alpha=0.05$ 
Diferenças entre Habilitações Académicas:

\begin{tabular}{|c|c|c|c|c|c|}
\hline & Variable & Estimate & $\begin{array}{l}\text { Std. } \\
\text { Error }\end{array}$ & $\begin{array}{l}\text { Critical Ratio } \\
\text { for diferences }\end{array}$ & Hypotheses Test \\
\hline & $\begin{array}{c}\text { Até } \\
\text { Secundário }\end{array}$ & 0.566 & 0.217 & \multirow[b]{2}{*}{0.06} & $\begin{array}{l}\text { Valor encontra-se dentro do } \\
\text { intervalo de confiança ]-1.96;1.96[ e }\end{array}$ \\
\hline $\begin{array}{c}\text { IE e } \\
\text { Motivação }\end{array}$ & $\begin{array}{l}\text { Ensino } \\
\text { Superior }\end{array}$ & 0.582 & 0.14 & & $\begin{array}{c}\text { assim não se rejeita Ho, logo não } \\
\text { existem diferenças significativas } \\
\text { entre os géneros masculino e } \\
\text { feminino }\end{array}$ \\
\hline \multirow[b]{2}{*}{$\begin{array}{l}\text { Motivação } \\
\text { e AD }\end{array}$} & $\begin{array}{l}\text { Até } \\
\text { Secundário }\end{array}$ & 0.633 & 0.198 & \multirow[b]{2}{*}{-1.045} & $\begin{array}{l}\text { Valor encontra-se dentro do } \\
\text { intervalo de confiança ]-1.96;1.96[e }\end{array}$ \\
\hline & $\begin{array}{l}\text { Ensino } \\
\text { Superior }\end{array}$ & 0.404 & 0.094 & & $\begin{array}{c}\text { assim não se rejeita Ho, logo não } \\
\text { existem diferenças significativas } \\
\text { entre os géneros masculino e } \\
\text { feminino }\end{array}$ \\
\hline
\end{tabular}

Teste bilateral $\operatorname{com} \alpha=0.05$ 
Diferenças entre Habilitações Académicas:

\begin{tabular}{|c|c|c|c|c|c|}
\hline & Variable & Estimate & $\begin{array}{l}\text { Std. } \\
\text { Error }\end{array}$ & $\begin{array}{l}\text { Critical Ratio } \\
\text { for diferences }\end{array}$ & Hypotheses Test \\
\hline & $\begin{array}{c}\text { Até } \\
\text { Secundário }\end{array}$ & 0.566 & 0.217 & \multirow[b]{2}{*}{0.06} & $\begin{array}{l}\text { Valor encontra-se dentro do } \\
\text { intervalo de confiança ]-1.96;1.96[ e }\end{array}$ \\
\hline $\begin{array}{c}\text { IE e } \\
\text { Motivação }\end{array}$ & $\begin{array}{l}\text { Ensino } \\
\text { Superior }\end{array}$ & 0.582 & 0.14 & & $\begin{array}{c}\text { assim não se rejeita Ho, logo não } \\
\text { existem diferenças significativas } \\
\text { entre os géneros masculino e } \\
\text { feminino }\end{array}$ \\
\hline \multirow[b]{2}{*}{$\begin{array}{l}\text { Motivação } \\
\text { e AD }\end{array}$} & $\begin{array}{l}\text { Até } \\
\text { Secundário }\end{array}$ & 0.633 & 0.198 & \multirow[b]{2}{*}{-1.045} & $\begin{array}{l}\text { Valor encontra-se dentro do } \\
\text { intervalo de confiança ]-1.96;1.96[e }\end{array}$ \\
\hline & $\begin{array}{l}\text { Ensino } \\
\text { Superior }\end{array}$ & 0.404 & 0.094 & & $\begin{array}{c}\text { assim não se rejeita Ho, logo não } \\
\text { existem diferenças significativas } \\
\text { entre os géneros masculino e } \\
\text { feminino }\end{array}$ \\
\hline
\end{tabular}

Teste bilateral $\operatorname{com} \alpha=0.05$ 
Diferenças entre Habilitações Académicas:

\begin{tabular}{|c|c|c|c|c|c|}
\hline & Variable & Estimate & $\begin{array}{l}\text { Std. } \\
\text { Error }\end{array}$ & $\begin{array}{l}\text { Critical Ratio } \\
\text { for diferences }\end{array}$ & Hypotheses Test \\
\hline & $\begin{array}{c}\text { Até } \\
\text { Secundário }\end{array}$ & 0.566 & 0.217 & \multirow[b]{2}{*}{0.06} & $\begin{array}{l}\text { Valor encontra-se dentro do } \\
\text { intervalo de confiança ]-1.96;1.96[ e }\end{array}$ \\
\hline $\begin{array}{c}\text { IE e } \\
\text { Motivação }\end{array}$ & $\begin{array}{l}\text { Ensino } \\
\text { Superior }\end{array}$ & 0.582 & 0.14 & & $\begin{array}{c}\text { assim não se rejeita Ho, logo não } \\
\text { existem diferenças significativas } \\
\text { entre os géneros masculino e } \\
\text { feminino }\end{array}$ \\
\hline \multirow[b]{2}{*}{$\begin{array}{l}\text { Motivação } \\
\text { e AD }\end{array}$} & $\begin{array}{l}\text { Até } \\
\text { Secundário }\end{array}$ & 0.633 & 0.198 & \multirow[b]{2}{*}{-1.045} & $\begin{array}{l}\text { Valor encontra-se dentro do } \\
\text { intervalo de confiança ]-1.96;1.96[e }\end{array}$ \\
\hline & $\begin{array}{l}\text { Ensino } \\
\text { Superior }\end{array}$ & 0.404 & 0.094 & & $\begin{array}{c}\text { assim não se rejeita Ho, logo não } \\
\text { existem diferenças significativas } \\
\text { entre os géneros masculino e } \\
\text { feminino }\end{array}$ \\
\hline
\end{tabular}

Teste bilateral $\operatorname{com} \alpha=0.05$ 
Diferenças entre Habilitações Académicas:

\begin{tabular}{|c|c|c|c|c|c|}
\hline & Variable & Estimate & $\begin{array}{l}\text { Std. } \\
\text { Error }\end{array}$ & $\begin{array}{l}\text { Critical Ratio } \\
\text { for diferences }\end{array}$ & Hypotheses Test \\
\hline & $\begin{array}{c}\text { Até } \\
\text { Secundário }\end{array}$ & 0.566 & 0.217 & \multirow[b]{2}{*}{0.06} & $\begin{array}{l}\text { Valor encontra-se dentro do } \\
\text { intervalo de confiança ]-1.96;1.96[ e }\end{array}$ \\
\hline $\begin{array}{c}\text { IE e } \\
\text { Motivação }\end{array}$ & $\begin{array}{l}\text { Ensino } \\
\text { Superior }\end{array}$ & 0.582 & 0.14 & & $\begin{array}{c}\text { assim não se rejeita Ho, logo não } \\
\text { existem diferenças significativas } \\
\text { entre os géneros masculino e } \\
\text { feminino }\end{array}$ \\
\hline \multirow[b]{2}{*}{$\begin{array}{l}\text { Motivação } \\
\text { e AD }\end{array}$} & $\begin{array}{l}\text { Até } \\
\text { Secundário }\end{array}$ & 0.633 & 0.198 & \multirow[b]{2}{*}{-1.045} & $\begin{array}{l}\text { Valor encontra-se dentro do } \\
\text { intervalo de confiança ]-1.96;1.96[e }\end{array}$ \\
\hline & $\begin{array}{l}\text { Ensino } \\
\text { Superior }\end{array}$ & 0.404 & 0.094 & & $\begin{array}{c}\text { assim não se rejeita Ho, logo não } \\
\text { existem diferenças significativas } \\
\text { entre os géneros masculino e } \\
\text { feminino }\end{array}$ \\
\hline
\end{tabular}

Teste bilateral $\operatorname{com} \alpha=0.05$ 
Diferenças entre Habilitações Académicas:

\begin{tabular}{|c|c|c|c|c|c|}
\hline & Variable & Estimate & $\begin{array}{l}\text { Std. } \\
\text { Error }\end{array}$ & $\begin{array}{l}\text { Critical Ratio } \\
\text { for diferences }\end{array}$ & Hypotheses Test \\
\hline & $\begin{array}{c}\text { Até } \\
\text { Secundário }\end{array}$ & 0.566 & 0.217 & \multirow[b]{2}{*}{0.06} & $\begin{array}{l}\text { Valor encontra-se dentro do } \\
\text { intervalo de confiança ]-1.96;1.96[ e }\end{array}$ \\
\hline $\begin{array}{c}\text { IE e } \\
\text { Motivação }\end{array}$ & $\begin{array}{l}\text { Ensino } \\
\text { Superior }\end{array}$ & 0.582 & 0.14 & & $\begin{array}{c}\text { assim não se rejeita Ho, logo não } \\
\text { existem diferenças significativas } \\
\text { entre os géneros masculino e } \\
\text { feminino }\end{array}$ \\
\hline \multirow[b]{2}{*}{$\begin{array}{l}\text { Motivação } \\
\text { e AD }\end{array}$} & $\begin{array}{l}\text { Até } \\
\text { Secundário }\end{array}$ & 0.633 & 0.198 & \multirow[b]{2}{*}{-1.045} & $\begin{array}{l}\text { Valor encontra-se dentro do } \\
\text { intervalo de confiança ]-1.96;1.96[e }\end{array}$ \\
\hline & $\begin{array}{l}\text { Ensino } \\
\text { Superior }\end{array}$ & 0.404 & 0.094 & & $\begin{array}{c}\text { assim não se rejeita Ho, logo não } \\
\text { existem diferenças significativas } \\
\text { entre os géneros masculino e } \\
\text { feminino }\end{array}$ \\
\hline
\end{tabular}

Teste bilateral $\operatorname{com} \alpha=0.05$ 
Diferenças entre Habilitações Académicas:

\begin{tabular}{|c|c|c|c|c|c|}
\hline & Variable & Estimate & $\begin{array}{l}\text { Std. } \\
\text { Error }\end{array}$ & $\begin{array}{l}\text { Critical Ratio } \\
\text { for diferences }\end{array}$ & Hypotheses Test \\
\hline & $\begin{array}{c}\text { Até } \\
\text { Secundário }\end{array}$ & 0.566 & 0.217 & \multirow[b]{2}{*}{0.06} & $\begin{array}{l}\text { Valor encontra-se dentro do } \\
\text { intervalo de confiança ]-1.96;1.96[ e }\end{array}$ \\
\hline $\begin{array}{c}\text { IE e } \\
\text { Motivação }\end{array}$ & $\begin{array}{l}\text { Ensino } \\
\text { Superior }\end{array}$ & 0.582 & 0.14 & & $\begin{array}{c}\text { assim não se rejeita Ho, logo não } \\
\text { existem diferenças significativas } \\
\text { entre os géneros masculino e } \\
\text { feminino }\end{array}$ \\
\hline \multirow[b]{2}{*}{$\begin{array}{l}\text { Motivação } \\
\text { e AD }\end{array}$} & $\begin{array}{l}\text { Até } \\
\text { Secundário }\end{array}$ & 0.633 & 0.198 & \multirow[b]{2}{*}{-1.045} & $\begin{array}{l}\text { Valor encontra-se dentro do } \\
\text { intervalo de confiança ]-1.96;1.96[e }\end{array}$ \\
\hline & $\begin{array}{l}\text { Ensino } \\
\text { Superior }\end{array}$ & 0.404 & 0.094 & & $\begin{array}{c}\text { assim não se rejeita Ho, logo não } \\
\text { existem diferenças significativas } \\
\text { entre os géneros masculino e } \\
\text { feminino }\end{array}$ \\
\hline
\end{tabular}

Teste bilateral $\operatorname{com} \alpha=0.05$ 
Diferenças entre Habilitações Académicas:

\begin{tabular}{|c|c|c|c|c|c|}
\hline & Variable & Estimate & $\begin{array}{l}\text { Std. } \\
\text { Error }\end{array}$ & $\begin{array}{l}\text { Critical Ratio } \\
\text { for diferences }\end{array}$ & Hypotheses Test \\
\hline & $\begin{array}{c}\text { Até } \\
\text { Secundário }\end{array}$ & 0.566 & 0.217 & \multirow[b]{2}{*}{0.06} & $\begin{array}{l}\text { Valor encontra-se dentro do } \\
\text { intervalo de confiança ]-1.96;1.96[ e }\end{array}$ \\
\hline $\begin{array}{c}\text { IE e } \\
\text { Motivação }\end{array}$ & $\begin{array}{l}\text { Ensino } \\
\text { Superior }\end{array}$ & 0.582 & 0.14 & & $\begin{array}{c}\text { assim não se rejeita Ho, logo não } \\
\text { existem diferenças significativas } \\
\text { entre os géneros masculino e } \\
\text { feminino }\end{array}$ \\
\hline \multirow[b]{2}{*}{$\begin{array}{l}\text { Motivação } \\
\text { e AD }\end{array}$} & $\begin{array}{l}\text { Até } \\
\text { Secundário }\end{array}$ & 0.633 & 0.198 & \multirow[b]{2}{*}{-1.045} & $\begin{array}{l}\text { Valor encontra-se dentro do } \\
\text { intervalo de confiança ]-1.96;1.96[e }\end{array}$ \\
\hline & $\begin{array}{l}\text { Ensino } \\
\text { Superior }\end{array}$ & 0.404 & 0.094 & & $\begin{array}{c}\text { assim não se rejeita Ho, logo não } \\
\text { existem diferenças significativas } \\
\text { entre os géneros masculino e } \\
\text { feminino }\end{array}$ \\
\hline
\end{tabular}

Teste bilateral $\operatorname{com} \alpha=0.05$ 
Diferenças entre Habilitações Académicas:

\begin{tabular}{|c|c|c|c|c|c|}
\hline & Variable & Estimate & $\begin{array}{l}\text { Std. } \\
\text { Error }\end{array}$ & $\begin{array}{l}\text { Critical Ratio } \\
\text { for diferences }\end{array}$ & Hypotheses Test \\
\hline & $\begin{array}{c}\text { Até } \\
\text { Secundário }\end{array}$ & 0.566 & 0.217 & \multirow[b]{2}{*}{0.06} & $\begin{array}{l}\text { Valor encontra-se dentro do } \\
\text { intervalo de confiança ]-1.96;1.96[ e }\end{array}$ \\
\hline $\begin{array}{c}\text { IE e } \\
\text { Motivação }\end{array}$ & $\begin{array}{l}\text { Ensino } \\
\text { Superior }\end{array}$ & 0.582 & 0.14 & & $\begin{array}{c}\text { assim não se rejeita Ho, logo não } \\
\text { existem diferenças significativas } \\
\text { entre os géneros masculino e } \\
\text { feminino }\end{array}$ \\
\hline \multirow[b]{2}{*}{$\begin{array}{l}\text { Motivação } \\
\text { e AD }\end{array}$} & $\begin{array}{l}\text { Até } \\
\text { Secundário }\end{array}$ & 0.633 & 0.198 & \multirow[b]{2}{*}{-1.045} & $\begin{array}{l}\text { Valor encontra-se dentro do } \\
\text { intervalo de confiança ]-1.96;1.96[e }\end{array}$ \\
\hline & $\begin{array}{l}\text { Ensino } \\
\text { Superior }\end{array}$ & 0.404 & 0.094 & & $\begin{array}{c}\text { assim não se rejeita Ho, logo não } \\
\text { existem diferenças significativas } \\
\text { entre os géneros masculino e } \\
\text { feminino }\end{array}$ \\
\hline
\end{tabular}

Teste bilateral $\operatorname{com} \alpha=0.05$ 
Diferenças entre Habilitações Académicas:

\begin{tabular}{|c|c|c|c|c|c|}
\hline & Variable & Estimate & $\begin{array}{l}\text { Std. } \\
\text { Error }\end{array}$ & $\begin{array}{l}\text { Critical Ratio } \\
\text { for diferences }\end{array}$ & Hypotheses Test \\
\hline & $\begin{array}{c}\text { Até } \\
\text { Secundário }\end{array}$ & 0.566 & 0.217 & \multirow[b]{2}{*}{0.06} & $\begin{array}{l}\text { Valor encontra-se dentro do } \\
\text { intervalo de confiança ]-1.96;1.96[ e }\end{array}$ \\
\hline $\begin{array}{c}\text { IE e } \\
\text { Motivação }\end{array}$ & $\begin{array}{l}\text { Ensino } \\
\text { Superior }\end{array}$ & 0.582 & 0.14 & & $\begin{array}{c}\text { assim não se rejeita Ho, logo não } \\
\text { existem diferenças significativas } \\
\text { entre os géneros masculino e } \\
\text { feminino }\end{array}$ \\
\hline \multirow[b]{2}{*}{$\begin{array}{l}\text { Motivação } \\
\text { e AD }\end{array}$} & $\begin{array}{l}\text { Até } \\
\text { Secundário }\end{array}$ & 0.633 & 0.198 & \multirow[b]{2}{*}{-1.045} & $\begin{array}{l}\text { Valor encontra-se dentro do } \\
\text { intervalo de confiança ]-1.96;1.96[e }\end{array}$ \\
\hline & $\begin{array}{l}\text { Ensino } \\
\text { Superior }\end{array}$ & 0.404 & 0.094 & & $\begin{array}{c}\text { assim não se rejeita Ho, logo não } \\
\text { existem diferenças significativas } \\
\text { entre os géneros masculino e } \\
\text { feminino }\end{array}$ \\
\hline
\end{tabular}

Teste bilateral $\operatorname{com} \alpha=0.05$ 
Diferenças entre Habilitações Académicas:

\begin{tabular}{|c|c|c|c|c|c|}
\hline & Variable & Estimate & $\begin{array}{l}\text { Std. } \\
\text { Error }\end{array}$ & $\begin{array}{l}\text { Critical Ratio } \\
\text { for diferences }\end{array}$ & Hypotheses Test \\
\hline & $\begin{array}{c}\text { Até } \\
\text { Secundário }\end{array}$ & 0.566 & 0.217 & \multirow[b]{2}{*}{0.06} & $\begin{array}{l}\text { Valor encontra-se dentro do } \\
\text { intervalo de confiança ]-1.96;1.96[ e }\end{array}$ \\
\hline $\begin{array}{c}\text { IE e } \\
\text { Motivação }\end{array}$ & $\begin{array}{l}\text { Ensino } \\
\text { Superior }\end{array}$ & 0.582 & 0.14 & & $\begin{array}{c}\text { assim não se rejeita Ho, logo não } \\
\text { existem diferenças significativas } \\
\text { entre os géneros masculino e } \\
\text { feminino }\end{array}$ \\
\hline \multirow[b]{2}{*}{$\begin{array}{l}\text { Motivação } \\
\text { e AD }\end{array}$} & $\begin{array}{l}\text { Até } \\
\text { Secundário }\end{array}$ & 0.633 & 0.198 & \multirow[b]{2}{*}{-1.045} & $\begin{array}{l}\text { Valor encontra-se dentro do } \\
\text { intervalo de confiança ]-1.96;1.96[e }\end{array}$ \\
\hline & $\begin{array}{l}\text { Ensino } \\
\text { Superior }\end{array}$ & 0.404 & 0.094 & & $\begin{array}{c}\text { assim não se rejeita Ho, logo não } \\
\text { existem diferenças significativas } \\
\text { entre os géneros masculino e } \\
\text { feminino }\end{array}$ \\
\hline
\end{tabular}

Teste bilateral $\operatorname{com} \alpha=0.05$ 
Diferenças entre Habilitações Académicas:

\begin{tabular}{|c|c|c|c|c|c|}
\hline & Variable & Estimate & $\begin{array}{l}\text { Std. } \\
\text { Error }\end{array}$ & $\begin{array}{l}\text { Critical Ratio } \\
\text { for diferences }\end{array}$ & Hypotheses Test \\
\hline & $\begin{array}{c}\text { Até } \\
\text { Secundário }\end{array}$ & 0.566 & 0.217 & \multirow[b]{2}{*}{0.06} & $\begin{array}{l}\text { Valor encontra-se dentro do } \\
\text { intervalo de confiança ]-1.96;1.96[ e }\end{array}$ \\
\hline $\begin{array}{c}\text { IE e } \\
\text { Motivação }\end{array}$ & $\begin{array}{l}\text { Ensino } \\
\text { Superior }\end{array}$ & 0.582 & 0.14 & & $\begin{array}{c}\text { assim não se rejeita Ho, logo não } \\
\text { existem diferenças significativas } \\
\text { entre os géneros masculino e } \\
\text { feminino }\end{array}$ \\
\hline \multirow[b]{2}{*}{$\begin{array}{l}\text { Motivação } \\
\text { e AD }\end{array}$} & $\begin{array}{l}\text { Até } \\
\text { Secundário }\end{array}$ & 0.633 & 0.198 & \multirow[b]{2}{*}{-1.045} & $\begin{array}{l}\text { Valor encontra-se dentro do } \\
\text { intervalo de confiança ]-1.96;1.96[e }\end{array}$ \\
\hline & $\begin{array}{l}\text { Ensino } \\
\text { Superior }\end{array}$ & 0.404 & 0.094 & & $\begin{array}{c}\text { assim não se rejeita Ho, logo não } \\
\text { existem diferenças significativas } \\
\text { entre os géneros masculino e } \\
\text { feminino }\end{array}$ \\
\hline
\end{tabular}

Teste bilateral $\operatorname{com} \alpha=0.05$ 
Diferenças entre Habilitações Académicas:

\begin{tabular}{|c|c|c|c|c|c|}
\hline & Variable & Estimate & $\begin{array}{l}\text { Std. } \\
\text { Error }\end{array}$ & $\begin{array}{l}\text { Critical Ratio } \\
\text { for diferences }\end{array}$ & Hypotheses Test \\
\hline & $\begin{array}{c}\text { Até } \\
\text { Secundário }\end{array}$ & 0.566 & 0.217 & \multirow[b]{2}{*}{0.06} & $\begin{array}{l}\text { Valor encontra-se dentro do } \\
\text { intervalo de confiança ]-1.96;1.96[ e }\end{array}$ \\
\hline $\begin{array}{c}\text { IE e } \\
\text { Motivação }\end{array}$ & $\begin{array}{l}\text { Ensino } \\
\text { Superior }\end{array}$ & 0.582 & 0.14 & & $\begin{array}{c}\text { assim não se rejeita Ho, logo não } \\
\text { existem diferenças significativas } \\
\text { entre os géneros masculino e } \\
\text { feminino }\end{array}$ \\
\hline \multirow[b]{2}{*}{$\begin{array}{l}\text { Motivação } \\
\text { e AD }\end{array}$} & $\begin{array}{l}\text { Até } \\
\text { Secundário }\end{array}$ & 0.633 & 0.198 & \multirow[b]{2}{*}{-1.045} & $\begin{array}{l}\text { Valor encontra-se dentro do } \\
\text { intervalo de confiança ]-1.96;1.96[e }\end{array}$ \\
\hline & $\begin{array}{l}\text { Ensino } \\
\text { Superior }\end{array}$ & 0.404 & 0.094 & & $\begin{array}{c}\text { assim não se rejeita Ho, logo não } \\
\text { existem diferenças significativas } \\
\text { entre os géneros masculino e } \\
\text { feminino }\end{array}$ \\
\hline
\end{tabular}

Teste bilateral $\operatorname{com} \alpha=0.05$ 
Diferenças entre Habilitações Académicas:

\begin{tabular}{|c|c|c|c|c|c|}
\hline & Variable & Estimate & $\begin{array}{l}\text { Std. } \\
\text { Error }\end{array}$ & $\begin{array}{l}\text { Critical Ratio } \\
\text { for diferences }\end{array}$ & Hypotheses Test \\
\hline & $\begin{array}{c}\text { Até } \\
\text { Secundário }\end{array}$ & 0.566 & 0.217 & \multirow[b]{2}{*}{0.06} & $\begin{array}{l}\text { Valor encontra-se dentro do } \\
\text { intervalo de confiança ]-1.96;1.96[ e }\end{array}$ \\
\hline $\begin{array}{c}\text { IE e } \\
\text { Motivação }\end{array}$ & $\begin{array}{l}\text { Ensino } \\
\text { Superior }\end{array}$ & 0.582 & 0.14 & & $\begin{array}{c}\text { assim não se rejeita Ho, logo não } \\
\text { existem diferenças significativas } \\
\text { entre os géneros masculino e } \\
\text { feminino }\end{array}$ \\
\hline \multirow[b]{2}{*}{$\begin{array}{l}\text { Motivação } \\
\text { e AD }\end{array}$} & $\begin{array}{l}\text { Até } \\
\text { Secundário }\end{array}$ & 0.633 & 0.198 & \multirow[b]{2}{*}{-1.045} & $\begin{array}{l}\text { Valor encontra-se dentro do } \\
\text { intervalo de confiança ]-1.96;1.96[e }\end{array}$ \\
\hline & $\begin{array}{l}\text { Ensino } \\
\text { Superior }\end{array}$ & 0.404 & 0.094 & & $\begin{array}{c}\text { assim não se rejeita Ho, logo não } \\
\text { existem diferenças significativas } \\
\text { entre os géneros masculino e } \\
\text { feminino }\end{array}$ \\
\hline
\end{tabular}

Teste bilateral $\operatorname{com} \alpha=0.05$ 
Diferenças entre Habilitações Académicas:

\begin{tabular}{|c|c|c|c|c|c|}
\hline & Variable & Estimate & $\begin{array}{l}\text { Std. } \\
\text { Error }\end{array}$ & $\begin{array}{l}\text { Critical Ratio } \\
\text { for diferences }\end{array}$ & Hypotheses Test \\
\hline & $\begin{array}{c}\text { Até } \\
\text { Secundário }\end{array}$ & 0.566 & 0.217 & \multirow[b]{2}{*}{0.06} & $\begin{array}{l}\text { Valor encontra-se dentro do } \\
\text { intervalo de confiança ]-1.96;1.96[ e }\end{array}$ \\
\hline $\begin{array}{c}\text { IE e } \\
\text { Motivação }\end{array}$ & $\begin{array}{l}\text { Ensino } \\
\text { Superior }\end{array}$ & 0.582 & 0.14 & & $\begin{array}{c}\text { assim não se rejeita Ho, logo não } \\
\text { existem diferenças significativas } \\
\text { entre os géneros masculino e } \\
\text { feminino }\end{array}$ \\
\hline \multirow[b]{2}{*}{$\begin{array}{l}\text { Motivação } \\
\text { e AD }\end{array}$} & $\begin{array}{l}\text { Até } \\
\text { Secundário }\end{array}$ & 0.633 & 0.198 & \multirow[b]{2}{*}{-1.045} & $\begin{array}{l}\text { Valor encontra-se dentro do } \\
\text { intervalo de confiança ]-1.96;1.96[e }\end{array}$ \\
\hline & $\begin{array}{l}\text { Ensino } \\
\text { Superior }\end{array}$ & 0.404 & 0.094 & & $\begin{array}{c}\text { assim não se rejeita Ho, logo não } \\
\text { existem diferenças significativas } \\
\text { entre os géneros masculino e } \\
\text { feminino }\end{array}$ \\
\hline
\end{tabular}

Teste bilateral $\operatorname{com} \alpha=0.05$ 
Diferenças entre Habilitações Académicas:

\begin{tabular}{|c|c|c|c|c|c|}
\hline & Variable & Estimate & $\begin{array}{l}\text { Std. } \\
\text { Error }\end{array}$ & $\begin{array}{l}\text { Critical Ratio } \\
\text { for diferences }\end{array}$ & Hypotheses Test \\
\hline & $\begin{array}{c}\text { Até } \\
\text { Secundário }\end{array}$ & 0.566 & 0.217 & \multirow[b]{2}{*}{0.06} & $\begin{array}{l}\text { Valor encontra-se dentro do } \\
\text { intervalo de confiança ]-1.96;1.96[ e }\end{array}$ \\
\hline $\begin{array}{c}\text { IE e } \\
\text { Motivação }\end{array}$ & $\begin{array}{l}\text { Ensino } \\
\text { Superior }\end{array}$ & 0.582 & 0.14 & & $\begin{array}{c}\text { assim não se rejeita Ho, logo não } \\
\text { existem diferenças significativas } \\
\text { entre os géneros masculino e } \\
\text { feminino }\end{array}$ \\
\hline \multirow[b]{2}{*}{$\begin{array}{l}\text { Motivação } \\
\text { e AD }\end{array}$} & $\begin{array}{l}\text { Até } \\
\text { Secundário }\end{array}$ & 0.633 & 0.198 & \multirow[b]{2}{*}{-1.045} & $\begin{array}{l}\text { Valor encontra-se dentro do } \\
\text { intervalo de confiança ]-1.96;1.96[e }\end{array}$ \\
\hline & $\begin{array}{l}\text { Ensino } \\
\text { Superior }\end{array}$ & 0.404 & 0.094 & & $\begin{array}{c}\text { assim não se rejeita Ho, logo não } \\
\text { existem diferenças significativas } \\
\text { entre os géneros masculino e } \\
\text { feminino }\end{array}$ \\
\hline
\end{tabular}

Teste bilateral $\operatorname{com} \alpha=0.05$ 
Diferenças entre Habilitações Académicas:

\begin{tabular}{|c|c|c|c|c|c|}
\hline & Variable & Estimate & $\begin{array}{l}\text { Std. } \\
\text { Error }\end{array}$ & $\begin{array}{l}\text { Critical Ratio } \\
\text { for diferences }\end{array}$ & Hypotheses Test \\
\hline & $\begin{array}{c}\text { Até } \\
\text { Secundário }\end{array}$ & 0.566 & 0.217 & \multirow[b]{2}{*}{0.06} & $\begin{array}{l}\text { Valor encontra-se dentro do } \\
\text { intervalo de confiança ]-1.96;1.96[ e }\end{array}$ \\
\hline $\begin{array}{c}\text { IE e } \\
\text { Motivação }\end{array}$ & $\begin{array}{l}\text { Ensino } \\
\text { Superior }\end{array}$ & 0.582 & 0.14 & & $\begin{array}{c}\text { assim não se rejeita Ho, logo não } \\
\text { existem diferenças significativas } \\
\text { entre os géneros masculino e } \\
\text { feminino }\end{array}$ \\
\hline \multirow[b]{2}{*}{$\begin{array}{l}\text { Motivação } \\
\text { e AD }\end{array}$} & $\begin{array}{l}\text { Até } \\
\text { Secundário }\end{array}$ & 0.633 & 0.198 & \multirow[b]{2}{*}{-1.045} & $\begin{array}{l}\text { Valor encontra-se dentro do } \\
\text { intervalo de confiança ]-1.96;1.96[e }\end{array}$ \\
\hline & $\begin{array}{l}\text { Ensino } \\
\text { Superior }\end{array}$ & 0.404 & 0.094 & & $\begin{array}{c}\text { assim não se rejeita Ho, logo não } \\
\text { existem diferenças significativas } \\
\text { entre os géneros masculino e } \\
\text { feminino }\end{array}$ \\
\hline
\end{tabular}

Teste bilateral $\operatorname{com} \alpha=0.05$ 
Diferenças entre Habilitações Académicas:

\begin{tabular}{|c|c|c|c|c|c|}
\hline & Variable & Estimate & $\begin{array}{l}\text { Std. } \\
\text { Error }\end{array}$ & $\begin{array}{l}\text { Critical Ratio } \\
\text { for diferences }\end{array}$ & Hypotheses Test \\
\hline & $\begin{array}{c}\text { Até } \\
\text { Secundário }\end{array}$ & 0.566 & 0.217 & \multirow[b]{2}{*}{0.06} & $\begin{array}{l}\text { Valor encontra-se dentro do } \\
\text { intervalo de confiança ]-1.96;1.96[ e }\end{array}$ \\
\hline $\begin{array}{c}\text { IE e } \\
\text { Motivação }\end{array}$ & $\begin{array}{l}\text { Ensino } \\
\text { Superior }\end{array}$ & 0.582 & 0.14 & & $\begin{array}{c}\text { assim não se rejeita Ho, logo não } \\
\text { existem diferenças significativas } \\
\text { entre os géneros masculino e } \\
\text { feminino }\end{array}$ \\
\hline \multirow[b]{2}{*}{$\begin{array}{l}\text { Motivação } \\
\text { e AD }\end{array}$} & $\begin{array}{l}\text { Até } \\
\text { Secundário }\end{array}$ & 0.633 & 0.198 & \multirow[b]{2}{*}{-1.045} & $\begin{array}{l}\text { Valor encontra-se dentro do } \\
\text { intervalo de confiança ]-1.96;1.96[e }\end{array}$ \\
\hline & $\begin{array}{l}\text { Ensino } \\
\text { Superior }\end{array}$ & 0.404 & 0.094 & & $\begin{array}{c}\text { assim não se rejeita Ho, logo não } \\
\text { existem diferenças significativas } \\
\text { entre os géneros masculino e } \\
\text { feminino }\end{array}$ \\
\hline
\end{tabular}

Teste bilateral $\operatorname{com} \alpha=0.05$ 